\title{
DEXTRAL STRIKE-SLIP FAULTING HISTORY OF THE MID-CRETACEOUS D'ABBADIE FAULT ZONE, PELLY MOUNTAINS, SOUTH-CENTRAL YUKON, CANADA
}

\author{
by \\ Mélanie Mercier \\ B.Sc. Honours in Earth Sciences, University of Ottawa, 2009
}

A thesis submitted to the Faculty of Graduate and Postdoctoral Affairs in partial fulfillment of the requirements for the degree of

Master of Science Degree

in

Earth Sciences

Carleton University

Ottawa, Ontario

(C) 2011, Mélanie Mercier 
THS

$$
\begin{aligned}
& \text { M.SC. } \\
& 2011 \\
& K 73
\end{aligned}
$$




\section{ABSTRACT}

The d'Abbadie fault zone is located in south-central Yukon, northeast of the Teslin fault. It is a north-striking, steeply dipping strike-slip fault with a strike length of $70 \mathrm{~km}$. There is a complex deformation and metamorphic history that predated the d'Abbadie fault zone where Paleozoic supracrustal rocks of the Last Peak succession, in the Yukon-Tanana terrane, were polydeformed and metamorphosed under greenschist facies conditions in the Permo-Triassic, and cooled in the Early Jurassic. This study focuses on history of a transect of the d'Abbadie fault zone, in the northeast portion of Livingstone Creek area (NTS 105E/8).

Geological mapping and structural analysis indicate that the d'Abbadie fault zone constitutes a $2 \mathrm{~km}$-wide zone of primarily anastomosing brittle dextral strike-slip faults, and a localized 200-500 m-wide strand of dextral S-C mylonites in the Last Peak granite. The brittle faults are filled with 2-30 m-wide cataclasites and $1 \mathrm{~mm}$ to $40 \mathrm{~cm}$-wide cataclasite zones that are distributed in variably sized strands along the faults. The cataclastic rocks form three domains: the Cataclasite, Mixed and Fracture domains. The $\mathrm{S}-\mathrm{C}$ mylonites form three domains: the Protomylonite, Mylonite and Ultramylonite domains.

The ca. 96 Ma Last Peak granite is a NW-SE striking, steeply dipping, variably foliated and mylonitic leucogranite that lies within the central part of the study area. Petrological and kinematic studies of the S-C mylonites show that the development and discrete distribution of the mylonites to the granite was facilitated by the heat of the pluton itself while it was intruding. Such heat made the rocks weak, which therefore made them susceptible to deform in a ductile manner under cold upper crustal conditions.

The Last Peak granite was syntectonic with the displacement of the d'Abbadie fault zone. Evidence includes the discrete distribution of the mylonitic rocks to within the pluton, cross cutting contacts, contact aureole, and the presence of an eastward ductile strain gradient within the Last Peak granite towards the centre of the d'Abbadie fault zone.

Sense of shear indicators that are preserved in both the cataclastic and mylonitic fault rocks provide the foundation for a kinematic analysis of the fault movement of the d'Abbadie fault zone. Structures and microstructures in mylonitic rocks in the syntectonic Last Peak granite and the relative motion on brittle shear fracture planes throughout the fault zone indicate that the d'Abbadie fault zone is a dextral strike-slip fault.

Timing of the deformation along the d'Abbadie fault is in part constrained by syntectonic emplacement of the ca. $96 \mathrm{Ma}$ Last Peak granite within the fault zone. Localized cataclasite zones, slickenlines on fault polished surfaces, and fractures 

overprint the $\mathrm{S}-\mathrm{C}$ mylonites in the Last Peak granite. These crosscutting relationships suggest that brittle faulting outlasted cooling of the granite and ductile deformation. Metamorphic conditions of the brittle and ductile rocks are confined to the greenschist facies. This is based on chlorite along fault surfaces and in strain shadows of K-feldspar porphyroclasts in mylonites in the syntectonic Last Peak granite.

The major deformation mechanism responsible for the formation of the cataclastic and brittle rocks include: cataclastic flow in and between grains, frictional grain-boundary sliding, and stress-induced solution transfer. Such mechanisms are consistent with a brittle deformation regime and are indicative of the rheology of a brittle crust. Therefore, the syntectonic depth-temperature conditions for the d'Abbadie fault zone are best estimated between $5-10 \mathrm{~km}$ and $<250{ }^{\circ} \mathrm{C}$.

The d'Abbadie fault zone is made of coherent fault rocks that are consistently distributed. This suggests that it has not undergone any significant reactivation and that it was a short-lived structure whose motion was restricted to the mid-Cretaceous, at ca. $96 \mathrm{Ma}$. 



\section{ACKNOWLEDGEMENTS}

I would like to sincerely acknowledge my supervisors, Drs. Sharon Carr and Maurice Colpron for their guidance, time, patience and discussions, and for sharing their invaluable knowledge with me throughout my Master's program.

I am grateful to the Yukon Geological Survey, Natural Sciences and Engineering Research Council of Canada through Discovery grants, to Drs. Carr and Colpron, and Carleton University for generous financial support throughout the project.

I especially wish to thank my field assistant lan Chappell for his outstanding and enthusiastic assistance in the field. We surely made a great mapping team together and stayed safe out of some Walrus trouble. Thanks to Neda Dokic who assisted me on the last leg of the summer.

Dr. David Schneider provided valuable instruction and advice on sample preparation and mineral selection for thermochronology, as well as helpful comments and discussions.

Nancy Joyce provided instruction on the operation of the Geological Survey of Canada Geochronology Argon laboratory, and analyzed $\mathrm{my}{ }^{40} \mathrm{Ar} /{ }^{39} \mathrm{Ar}$ samples, with the help of Ellie Knight.

I would like to extend my appreciation to Jiri Mrazek in the rock cutting lab at the University of Ottawa, Al Alcazar and Mike Jackson in the rock cutting lab at Carleton University, and Vancouver Petrographics for preparing fine and clear thin sections.

Thanks to Capital Helicopters for their professional and safe work practices while flying in the field, and for their thoughtful treats.

I would like to thank all the professors and my geology schoolmates in the Earth Sciences department at Carleton University, for their encouragement, scientific conversations, and making my University years so memorable.

Last, but not least, I wish to extend a special thank you to my family and friends that I love "gros comme le ciel", for their infinite support of whatever challenges I may undertake. 



\section{ORIGINAL CONTRIBUTIONS}

Work on the d'Abbadie fault project in the northern Canadian Cordillera began in the summer of 2008 with an introduction to rocks of the Yukon-Tanana terrane while working for the Yukon Geological Survey as field assistant to Liz Westberg. Work mainly consisted of doing 1:20 000 to 1: 50000 scale geological mapping of the Mendocina Creek area (map sheet 105F/5) in the Pelly Mountains, Yukon, and including a traverse across the d'Abbadie fault zone. Preliminary mapping at strategic locations within the d'Abbadie fault zone for few days was conducted in company of my thesis supervisors, Drs. Sharon Carr and Maurice Colpron, to look at mylonites in the Last Peak granite and Mendocina orthogneiss, collect a preliminary suite of samples and take structural measurements.

During the summer of 2009, I carried out 6 weeks of geological and structural mapping at 1: 10000 scale of a transect across the d'Abbadie fault zone, part of the Livingstone Creek area, located in the Pelly Mountains. Mapping was carried out by means of fly camping at 4 different locations along the fault zone. Particular attention was paid to structural observations and sample collecting in a transect across the fault zone. The map (Fig. 6) is an original contribution and was made using ArcGIS software. I completed a structural analysis through microscopy and petrography to characterize both brittle fault rocks and brittle structures in the d'Abbadie fault zone and ductile mylonites within the syn-tectonic mid-Cretaceous Last Peak granite located within the fault zone. I have created two structural maps; one of the brittle zones (Fig. 11) and one of the Last Peak granite (Fig. 16). Data are synthesized in Tables 1, 2, 3 and 4.

$\mathrm{A}^{40} \mathrm{Ar} /{ }^{39} \mathrm{Ar}$ thermochronology study of muscovites and biotites from four samples from a transect of the d'Abbadie fault zone was conducted at the Geological Survey of Canada geochronology laboratory by Nancy Joyce, and with the help of Ellie Knight. I completed sample crushing, mineral separation, mineral selection and interpretation. Although results of this study do not provide substantial answers to the original questions, details of the analytical methods and data are presented in Appendix. 



\section{METHOD OF PRESENTATION}

This thesis is presented as one paper including sections 1 to 8 , each approaching different aspects of the history of the d'Abbadie fault zone.

Section 1 introduces the d'Abbadie fault zone, tectonic setting, topic of research objectives, and presents an historical review of the previous work accomplished in proximity to the d'Abbadie fault zone.

Section 2 describes the regional geological setting of the d'Abbadie fault zone with respect to the Yukon-Tanana terrane, and introduces the geology of the d'Abbadie fault zone.

Section $\mathbf{3}$ focuses on a structural analysis of the d'Abbadie fault zone and descriptions of the geometry of the fault zone, fault rocks, rock textures, microstructures, and kinematics.

Section 4 provides an analysis of the data presented in Section 3 including discussions of the operative deformation mechanisms and processes, interpretations of crustal depth and temperature conditions during formation of the d'Abbadie fault zone and interpretations of the results.

Section 5 presents a summary of conclusions.

Section 6 provides recommendations for future work on the d'Abbadie fault and/or surrounding area. 



\section{TABLE OF CONTENTS}

ABSTRACT
ACKNOWLEDGEMENTS.
ORIGINAL CONTRIBUTION.
METHOD OF PRESENTATION
LABTE OF CONTENTS OF FIGURES
LIST OF TABLES
LIST OF APPENDIXX

SECTION 1 - INTRODUCTION AND TECTONIC SETTING OF THE D'ABBADIE FAULT ZONE... 1

1.1 Introduction and tectonic setting of the d'Abbadie fault zone.................................... 2

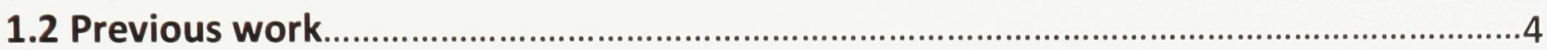

1.3 Purpose, objectives and rationale of study.............................................................. 12

SECTION 2 - REGIONAL GEOLOGY OF THE D'ABBADIE FAULT ZONE................................. 14

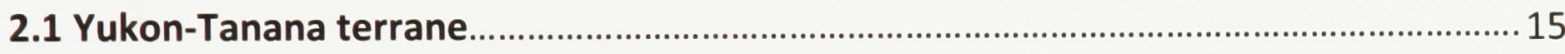

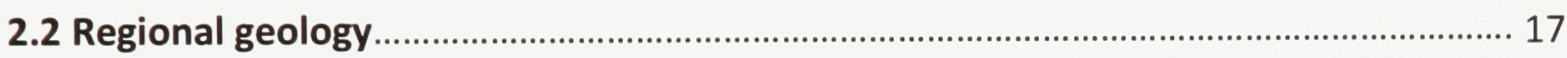

2.3 Geology of a transect of the d'Abbadie fault zone................................................. 23

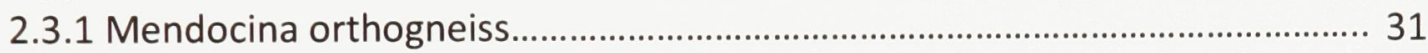

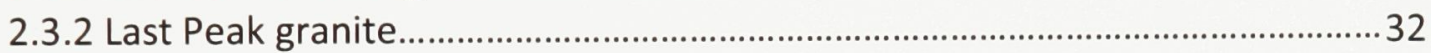

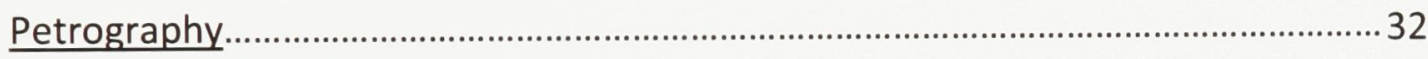

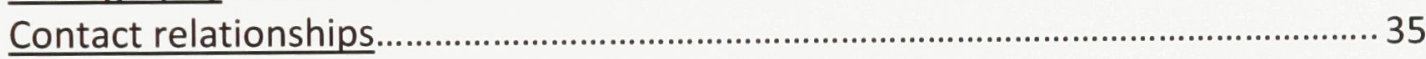

SECTION 3 - STRUCTURE OF THE D'ABBADIE FAULT ZONE

3.1 Fault rocks in a transect across the d'Abbadie fault zone............................................. 39

3.1.1 Domains in the cataclastic and fractured rocks.............................................. 50

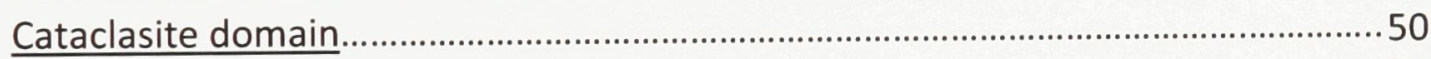

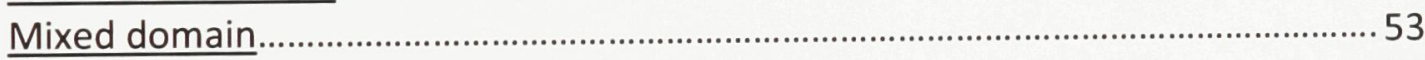

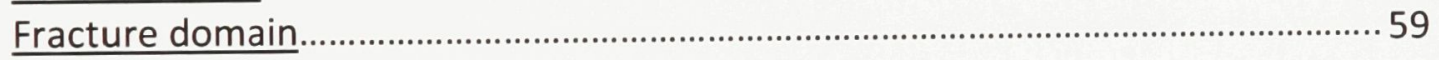

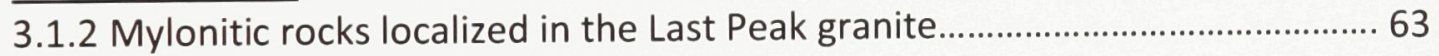

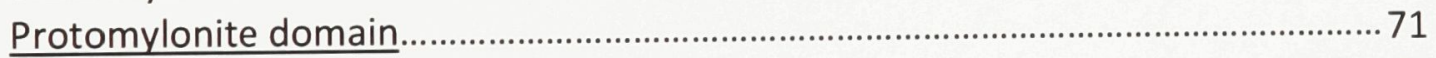

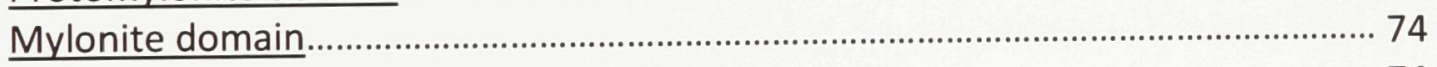

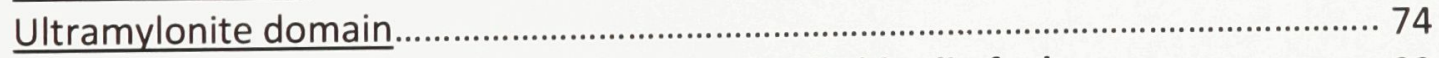

3.2 Structure of a representative transect across the d'Abbadie fault zone..................... 82

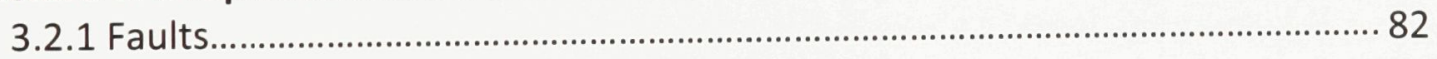

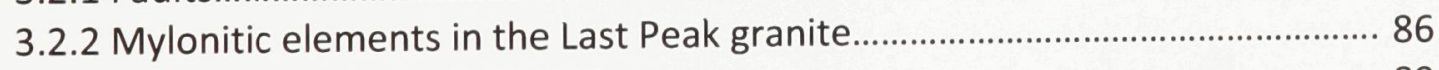

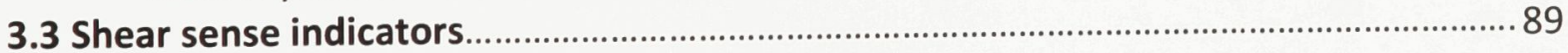

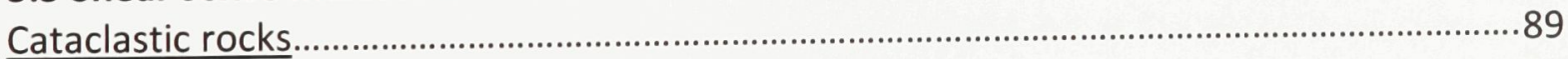

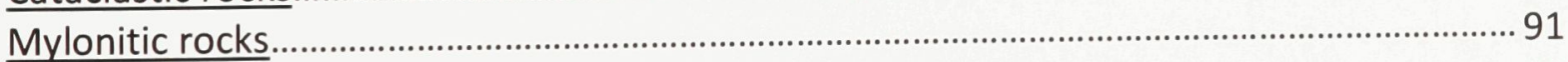

3.4 Metamorphic mineral occurrences in the transect..................................................... 98

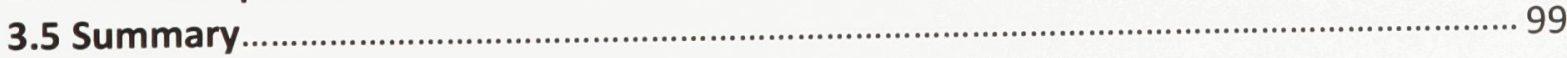



SECTION 4 - DISCUSSION AND IMPLICATIONS.

4.1 Cataclastic and fractured rocks in the d'Abbadie fault zone.......................................... 104

4.2 The Last Peak granite is syntectonic with the d'Abbadie fault zone............................. 105

4.3 Sense and estimate of the magnitude of displacement on the d'Abbadie fault zone 106

4.4 Timing of displacement on the d'Abbadie fault zone. 109

4.5 Retrograde metamorphism in the d'Abbadie fault zone

4.6 Deformation regime, rheology and indicators of depth-temperature conditions.

4.6.1 Deformation regime and rheology in the d'Abbadie fault zone

4.6.2 Syntectonic depth-temperature indicators

4.7 Regional significance of the d'Abbadie fault zone transect.

Orientation of the fault transect in contrast with the whole fault length.

Significance of the d'Abbadie fault zone with respect to the Teslin fault.

Late faults cutting across the d'Abbadie fault zone.

4.8 Implication for reactivation.

SECTION 5 - SUMMARY OF CONCLUSIONS.

SECTION 6 - FUTURE RECOMMENDATIONS

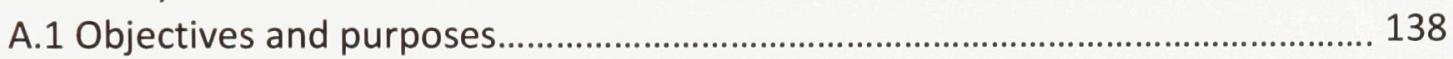

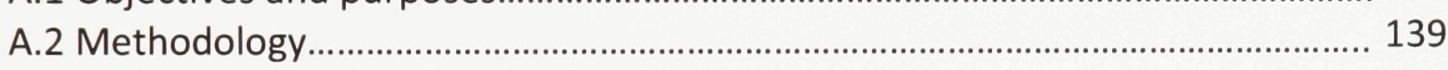

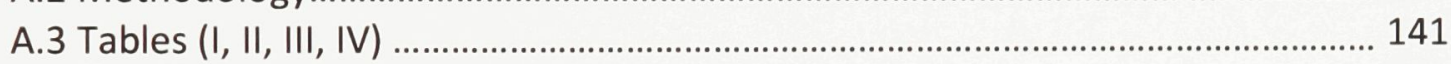

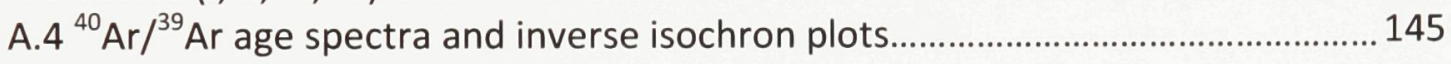





\section{LIST OF FIGURES}

Figure 1. Map of Yukon and adjacent provinces illustrating a system of mid-Cretaceous 3 dextral strike-slip faults in the northern Canadian Cordillera (modified after Gabrielse et al. 2006).

Figure 2. Tectonic models presented by previous workers around the d'Abbadie fault 6 zone.

Figure 3. Terranes of the Cordillera showing the spatial relation of Yukon-Tanana terrane16 with Insular and Ancestral North America superterranes (after Colpron et al. 2007).

Figure 4. Simplified terrane map showing the spatial relation of the d'Abbadie fault zone 18 with the Yukon-Tanana terrane, Cretaceous plutonic suites and Teslin fault (after Colpron 2010).

Figure 5. Simplified geology map of the Livingstone Creek area (NTS 105E/8) (after 20 Colpron 2005a).

Figure 6. Geological map of a transect of the d'Abbadie fault zone, in the top northeastern portion of the Livingston Creek area (Fig. 5).

Figure 7. Mesoscopic field shots of selected supracrustal rocks and intrusive rocks around a transect of the d'Abbadie fault zone.

Figure 8. Mesoscopic field photographs of the Last Peak granite.

Figure 9. Photograph of the contact between the Mendocina orthogneiss and the Last 36 Peak granite.

Figure 10. Map of the outcrop control and a photograph showing the field exposures of 40 the d'Abbadie fault zone.

Figure 11. Structural map of the domains in a $2 \mathrm{~km}$-wide transect of the d'Abbadie fault 48 zone.

Figure 12. Representative photographs and photomicrographs of fault rocks from the Cataclasite domain.

Figure 13. Representative photographs and photomicrographs of the fault rocks from the Mixed domain.

Figure 14. Representative photographs and photomicrograph of localized breccias from 57 the Mixed domain. 

Figure 15. Representative photographs and photomicrograph of rocks from the Fracture 60 domain.

Figure 16. Structural domain map of the Last Peak granite.

Figure 17. Representative photograph and photomicrographs of protomylonites from 72 the Protomylonite domain in the Last Peak granite.

Figure 18. Representative photograph and photomicrographs of mylonites from the Mylonite domain in the Last Peak granite.

Figure 19. Representative photog raph and photomicrographs of ultramylonites from the Ultramylonite domain in the Last Peak granite.

Figure 20. Brittle structures overprinting mylonites in the Last Peak granite.

Figure 21. Structural map of the faults within the d'Abbadie fault zone.

Figure 22. Structural map of the Last Peak granite.

Figure 23. Brittle shear sense indicator from the supracrustal rocks in the d'Abbadie fault zone.

Figure 24. Notions of simple shear and motion plane for the mylonitic rocks in the Last Peak granite.

Figure 25. Photomicrographs of shear sense indicators and potential shear sense 96 markers from the mylonitic fault rocks in the d'Abbadie fault zone.

Figure 26. Map showing the distribution of cataclastic fault rocks and fractured rocks 100 with respect to mylonitic fault rocks in a transect of the d'Abbadie fault zone.

Figure 27. Best estimate of plane simple shear strain deformation with minor general 110 flattening with respect to the Flinn diagram for constant volume deformation (introduced by the British geologist Derek Flinn 1962).

Figure 28. Structures and microstructures in the cataclastic and brittle rocks in the d'Abbadie fault zone placed in the context of a conceptual model for fault zones (modified after Knipe 1989; and Alsop and Holdsworth 2004).

Figure 29. General diagram showing the potential deformation regime, crustal conditions, fault rocks, deformation mechanisms of the d'Abbadie fault zone (modified after Knipe 1989; Alsop and Holdsworth 2004). 



\section{LIST OF TABLES}

Table 1. Lithology of the map units in and adjacent to the d'Abbadie fault zone........ 29

Table 2. Cataclastic and fractured rocks in the d'Abbadie fault zone 43

Table 3. Mylonitic fault rocks localized in the Last Peak granite. 66

Table 4. Microstructures in the Last Peak granite. 70

Table 5. Estimation of a portion of the displacement on the d'Abbadie fault zone. 108

\section{LIST OF APPENDIX}

Appendix. ${ }^{40} \mathrm{Ar} /{ }^{39} \mathrm{Ar}$ thermochronology. 

SECTION 1 - INTRODUCTION AND

TECTONIC SETTING OF THE D'ABBADIE FAULT ZONE 


\subsection{Introduction and tectonic setting of the d'Abbadie fault zone}

The Canadian Cordillera is dissected by crustal-scale post-accretionary transcurrent faults. These faults consist of arrays of mid- to Late Cretaceous anastomosing faults that have experienced $10 \mathrm{~s}$ to $100 \mathrm{~s}$ of $\mathrm{km}$ displacement. Larger-scale Eocene faults have experienced $100 \mathrm{~s}$ to $400 \mathrm{~s}$ of $\mathrm{km}$ displacement. The Cretaceous faults are interpreted to have originated due to the oblique convergence of the Pacific plate with the North American plate (Gabrielse et al. 2006), but their origin is debated, as the significance and relationship of intraplate structures to plate tectonics is complex (Molnar 1988). The regime is interpreted to have switched to transtensional in the Eocene (Gabrielse et al. 2006).

In Yukon, the anastomosing strike-slip faults part of the Cretaceous system include the Teslin and related Big Salmon and d'Abbadie faults, and partly the Cassiar fault (Fig. 1). Although they have well-defined map expressions, they are for the most part not exposed. This therefore makes the interpretation of the structural history of Cretaceous faulting in the northern Canadian Cordillera extremely challenging, as fundamental geological and structural information is uncertain. One exception is the d'Abbadie fault.

The d'Abbadie fault is mappable for $70 \mathrm{~km}$ along its strike-length. It is located $100 \mathrm{~km}$ northeast of Whitehorse, northeast of the Teslin fault, in south-central Yukon (Fig. 1). During the mid-Cretaceous, the d'Abbadie fault along with other intraplate 


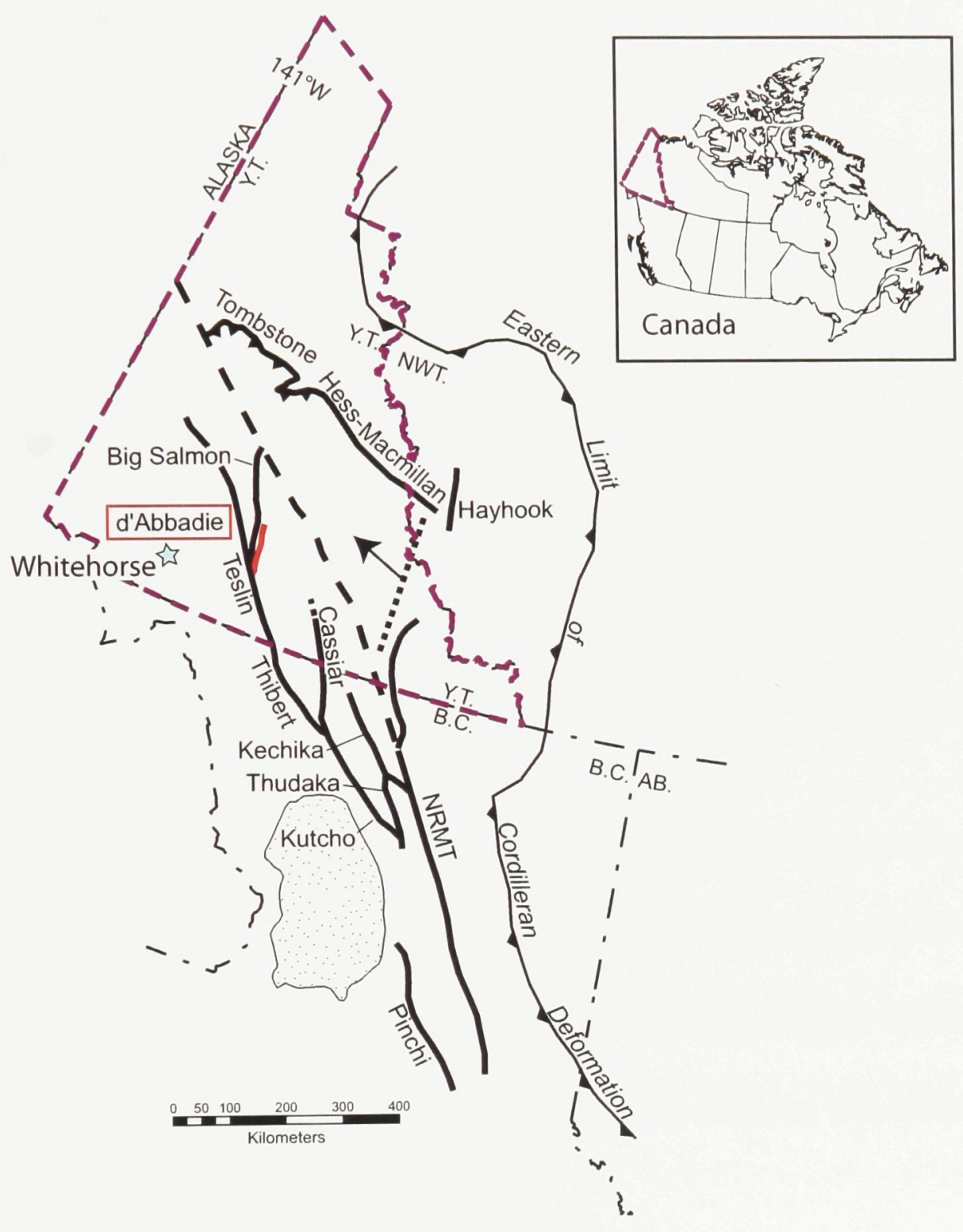

(modified after Gabrielse et al. 2006)

Figure 1

Figure 1. Map of Yukon and adjacent provinces illustrating the spatial relation of the d'Abbadie fault zone with other mid-Cretaceous dextral, strike-slip faults in the northern Canadian Cordillera (modified after Gabrielse et al. 2006). NRMT - Northern Rocky Mountain Trench. Mass with dots - Bowser basin. Dotted line - Axis of inferred extensional zone of Early Cretaceous extension connecting Big Salmon fault with HessMacmillan fault system. Arrow - inferred extension direction. 
transcurrent faults (Storti et al. 2003) such as the Teslin fault, locally truncated supracrustal rocks with complex deformation and metamorphic histories. Strike-slip faulting was coeval with extensive mid-Cretaceous plutonism (Gabrielse et al. 2006). Examples include; the mid-Cretaceous Cassiar batholith (Mortensen et al. 2006) associated with the Cassiar fault (Gabrielse et al. 2006); and most important to this study, the mid-Cretaceous Last Peak granite (Gallagher 1999) associated with the d'Abbadie fault zone (this study; see Section 4.2). Faulting and plutonism was active in a back-arc environment related to subduction at the western margin of North America (Gabrielse et al. 2006). In the Eocene, some of the Cretaceous faults were offset by strike-slip displacement on faults like the Tintina fault (Fig. 1).

\subsection{Previous work}

The goal of this section is to present the previous geological work in the vicinity of the d'Abbadie fault zone and related tectonic models. It is important to note that the previous models mostly focused on interpreting ductile deformation history of the supracrustal rocks adjacent to the d'Abbadie fault zone, and that this history predates that of the d'Abbadie fault zone.

Geological mapping of the Laberge map area (105E), which contains the d'Abbadie fault zone, was initiated in the 1930's by Bostock and Lees (1938). They identified the extensive distribution of volcanic and sedimentary packages. They also recognized the economic potential of the Livingstone Creek from gold discoveries in the area, but sources of which remain elusive. Tempelman-Kluit $(1979,1984)$ later 
conducted mapping in the Laberge map area. He was the first to recognize the d'Abbadie fault, which he interpreted as a steeply dipping thrust fault bounding an approximately north-striking, steeply dipping, $20 \mathrm{~km}$-wide mélange zone, termed the Teslin Suture zone. The Teslin Suture zone included rocks between d'Abbadie and Big Salmon faults. Tempelman-Kluit (1979) suggested that rocks of the Teslin suture zone were juxtaposed with rocks deposited on the margin of Laurentia to the east along d'Abbadie fault. These two entities were referred to as the Yukon Cataclastic complex and Cassiar terranes. Tempelman-Kluit's interpretation of the boundary and the mélange was made on the basis of the steepness, complexity of deformation and apparent discontinuity of the supracrustal rocks in the Teslin Suture Zone, together with the occurrence of eclogite-facies rocks to the north of Livingstone Creek area (NTS 105E/8).

Subsequent work by Hansen $(1989)$ and Hansen et al. $(1989,1991,1992)$ built upon Tempelman-Kluit's tectonic model. Hansen et al. (1989) mapped a transect across the Teslin Suture zone. She divided the Teslin Suture zone into three structural domains on the basis of the variation of the orientation of mylonitic structures, steep cleavages and of shear sense indicators (Fig. 2a1, 2, 3). Based on these domains and varying reverse to dip-slip motions, Hansen interpreted the Teslin Suture zone as a subduction channel, i.e. a west-dipping subduction complex that was operating in Permian to Triassic time. Hansen further suggested that the steep arrangement of the supracrustal rocks, together with the variation and apparent fanning of the foliation across the zone were evidence supporting the presence of a flower structure. 
Figure 2. Tectonic models for the d'Abbadie fault zone presented by previous workers. (a) Block diagram, modified after Hansen (1989), of the Late to Middle Jurassic subduction complex divided into 3 distinct zones on the basis of their slip motion (1, dip-slip; 2, strikeslip; 3, klippen) which altogether represents her interpretation of the flower structure. 4 Late Cretaceous plutons; 5, DFZ - d'Abbadie fault zone. (b) Tectonic model of Stevens and Erdmer (1996). See text for explanation. (c) Simplified structural cross-section of the Last Peak area showing a component of late normal-slip along the d'Abbadie fault zone (de Keijzer and Williams 1998; de Keijzer 2000). The lithologic contacts have been transposed during $F_{2}$ folding and were later rotated by $\mathrm{km}$-scale $F_{3}$ folding. Note that the rocks within the west limb are steeply dipping where the one within the eastern limb are moderately to shallowly dipping. 


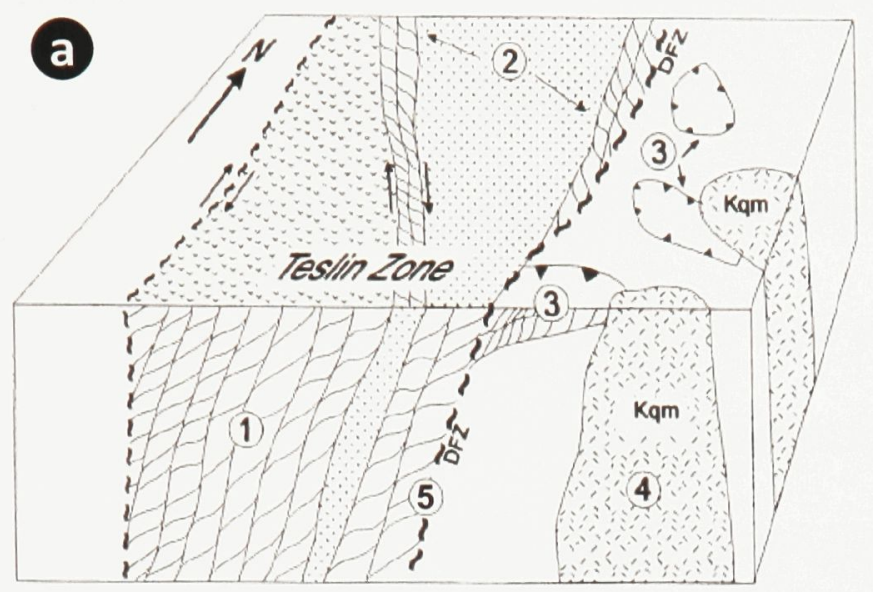

(modified after Hansen 1989)

b i) Early - Mid - Cretacoous

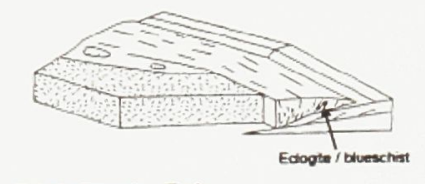

ii) Late Triassic - Early

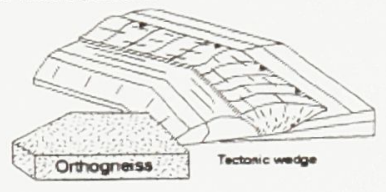

iii) Permian - Early Triassic
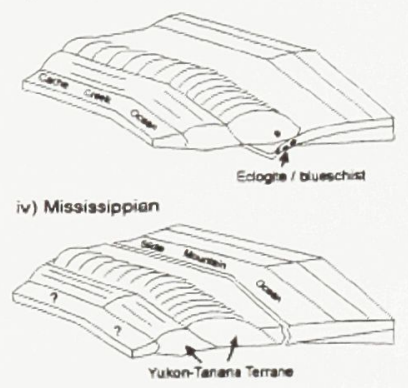

(Stevens and Erdmer 1996)

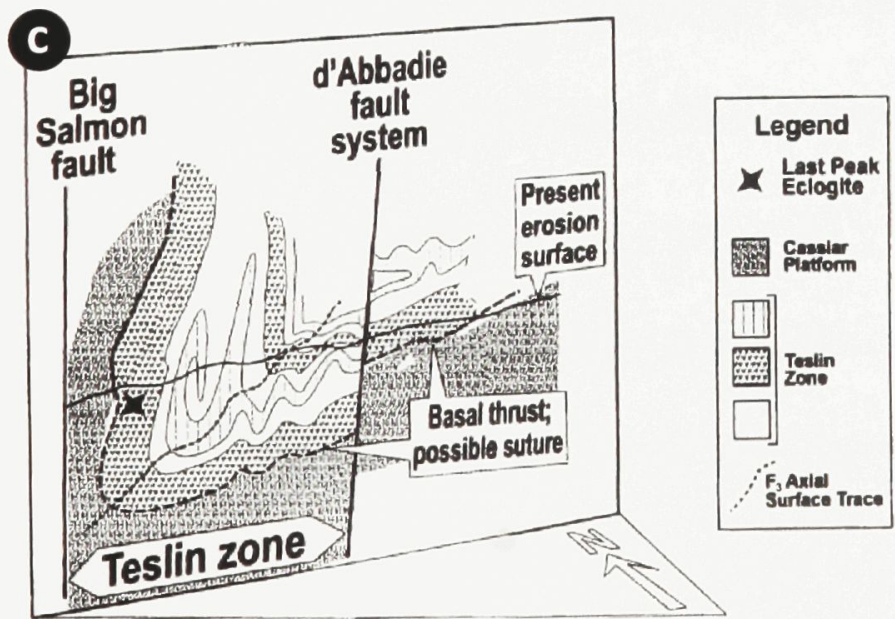

(de Keijzer and Williams 1998; de Keijzer 2000)

Figure 2 
Such a flower structure was interpreted to have been later transected by the d'Abbadie fault zone. She also recognized dextral strike-slip kinematic indicators in mylonites of an intrusive body (now known as two separate intrusions: the Mendocina orthogneiss and the Last Peak granite; Gallagher 1999). These mylonites and strike-slip sense of shear indicators also led Hansen to associate the formation of the mylonites with a component of strike-slip sense of displacement on the d'Abbadie fault zone. Hansen also conducted ${ }^{40} \mathrm{Ar} /{ }^{39} \mathrm{Ar}$ thermochronology studies of a transect across the Teslin Suture zone constraining the cooling history of part of the area to Early Jurassic, with a younger Cretaceous cooling history near the d'Abbadie fault zone.

Stevens (1994), Stevens et al. (1996) and Stevens and Erdmer (1996) concentrated their research on the rocks that occur along the southeast extension of the Teslin suture zone, which they rename the Teslin tectonic zone. They built their research upon Hansen's model of a flower structure, and mapping of three transects across the Teslin tectonic zone. Stevens et al. (1996) suggested a model where the Teslin tectonic zone is a thrust-transpressive shear zone at the ductile base of the flower structure. During the Mississippian, sediments were deposited along the distal North American shelf and later formed assemblages referred to as Nisutlin and Anvil assemblages (Fig. 2biv). The subduction of oceanic crust under a magmatic arc in the Permian to Early Triassic created eclogite-facies metamorphism along the basal contact between the assemblages (Fig. 2biii). The supracrustal rocks forming the flower structure (Steven's tectonic wedge), were thrusted onto North America along a basal décollement in the Late Triassic-Jurassic (Fig. 2bii), and eclogite-facies rocks were 
incorporated into the Teslin rocks from the westward subduction zone. The variation and unique orientation of the linear and planar structures in the domains that Stevens identified in the flower structure are accounted for by a combination of compression, wrenching and extrusion processes. As for the d'Abbadie fault zone, it is recognized as a strike-slip fault, like the Teslin and Big Salmon fauts, that overprinted the flower structure during Early to mid-Cretaceous (Fig. 2bi).

Subsequent work by Harvey et al. $(1996,1997)$, de Keijzer et al. (1999) de Keijzer (2000), Gallagher (1999), and Colpron $(2005 a, b ; 2006 a, b)$ did not support the previous models of a mélange, flower structure or wedge. They mapped continuous marker layers and could account for the map geometry with polyphase folding of a transposition foliation, despite an overprint by a younger steep penetrative cleavage. de Keijzer and Williams (1996), de Keijzer et al. (1999), and de Keijzer (2000) conducted detailed structural mapping in the Last Peak area, between the Big Salmon and d'Abbadie fault zones, and in Cassiar Terrane, to the northeast of Livingstone Creek area (NTS 105E/8) to constrain the Teslin zone. de Keijzer identified that steeply dipping rocks to the west of the d'Abbadie fault zone have structures that are consistent with the structures in moderately to shallowly dipping rocks to the east of the fault zone (Fig. 2c). To explain such contrast in dip orientation, his model suggests that the supracrustal rocks in the Teslin zone mapped by Tempelman-Kluit $(1979,1984)$ and Hansen (1989) underwent penetrative deformation and formation of a strong penetrative transposition foliation during $F_{2}$ folding prior to $F_{3} \mathrm{~km}$-scale folding. As for the d'Abbadie fault zone, it is referred to as a subsidiary late normal fault, on the basis of local observations of 
components of normal slip. In contrast, Gallagher (1999) recorded no significant normal or reverse motion in his respective study area, the Dycer Creek area (northeast portion of Livingstone Creek, NTS 105E8), but rather recorded strike-slip motion.

Through detailed geological mapping in the Dycer Creek area that comprises rocks on either side of the d'Abbadie fault zone, in the northeast portion of Livingstone Creek area, Gallagher (1999) identified mappable stratigraphic successions. Gallagher's (1999) work built upon de Keijzer's (2000). Along with stratigraphic and structural continuity of the rock units in the vicinity of the d'Abbadie fault zone, Gallagher (1999) provided the first age constraints on the Last Peak granite (ca. $96 \mathrm{Ma}$ ) and the Mendocina orthogneiss (ca. $358 \mathrm{Ma}$ ) and showed that these represent two distinct intrusions.

de Keijzer (2000) and Gallagher (1999), in each of their study areas, together with preliminary work by Harvey et al. $(1996,1997)$, were able to demonstrate a structural continuity across the region, which is therefore inconsistent with the mélange of Tempelman-Kluit $(1979,1984)$. This also limits the potential displacement across the d'Abbadie fault zone. Their findings suggest that the d'Abbadie fault zone is not a major tectonic boundary that separates terranes with contrasting deformation histories.

Colpron $(2005 a, b ; 2006 a, b)$ conducted 1: 50 000-scale regional mapping of the Livingstone Creek area and other areas constituting Yukon-Tanana and Cassiar terranes. Colpron's work ties together previous results (Harvey 1995-1996, unpublished data; Harvey et al. 1996, 1997; Gallagher 1999; and de Keijzer 2000). As opposed to previous 
interpretations (Tempelman-Kluit 1979, 1984; Hansen 1989; Hansen et al. 1989, 1991, 1992; Stevens 1994; Stevens et al. 1996; and Stevens and Erdmer 1996) where the d'Abbadie fault was taken as the eastern boundary of the Yukon-Tanana terrane Colpron concluded that rocks on both sides of the d'Abbadie fault zone belong to the Yukon-Tanana terrane (Colpron et al. 2006b). This calls for a new location for the boundary between Yukon-Tanana and Cassiar terranes.

Recent interpretations of the geology in the Mendocina Creek area (105F/5), east of the d'Abbadie fault zone, suggest that the boundary between the Yukon-Tanana and Cassiar terranes is located approximately 20 kilometres east of the d'Abbadie fault zone (Westberg et al. 2009; Westberg 2009, 2010). This is based on the thrust-fault relationship between two lithologic successions. Such relocation of the terrane boundary is consistent with suggestions from Gallagher (1999) and Colpron (2005a, b; $2006 a, b)$, and therefore has put an end to the previous interpretation of the d'Abbadie fault zone being a terrane-bounding structure.

Results of the previous studies indicate that the d'Abbadie fault zone is an approximately $70 \mathrm{~km}$ long, north-striking and steeply dipping strike-slip fault that transects polydeformed supracrustal rocks that are correlative and share a similar deformation history on either side of the fault zone. Although Harvey et al. $(1996,1997)$, Gallagher (1999), and Colpron $(2005 a, b ; 2006 a, b)$ had recognized both the ductile and brittle structures related to the d'Abbadie fault zone prior to this study, a detailed 
documentation of the structures and their relationships to each other had not been carried out.

\subsection{Purpose, objectives and rationale of study}

This study was conducted along a transect of the d'Abbadie fault zone to contribute to the understanding of strike-slip faulting in the Canadian Cordillera, constrain the knowledge about the d'Abbadie fault zone, characterize the brittle and/or ductile deformation history of the d'Abbadie fault zone, and the anatomy of the d'Abbadie fault zone. Part of this work is a continuation of the work initiated by J.L. Harvey in 1995 and builds upon that of Gallagher (1999), de Keijzer (2000) and Colpron $(2005 a, b ; 2006 a, b)$.

The objectives of this study are to characterize the structural history of the d'Abbadie fault zone by determining the geometry, size, sense of displacement, timing of deformation, structural style, deformation regime, rheology, and depth-temperature conditions of the active fault zone.

Geological and structural mapping at 1: 10000 -scale was undertaken to produce detailed geological and structural maps and collect samples in a transect across the d'Abbadie fault zone. Structural petrological studies of the brittle fault rocks, such as studies of the ubiquitous cataclasites, were carried out to determine the type of processes and mechanisms that operated during faulting, and the crustal conditions of deformation, i.e. an estimation of the depth and temperature conditions while the fault was active. Petrological and kinematic studies of the S-C mylonites that occur within the 
Last Peak granite were carried out to document the micro-scale textures and structures which can provide information about deformation mechanisms, temperature conditions of deformation in the granite and the sense of displacement for a particular fault. Sense of shear indicators that are preserved in the both the cataclastic and mylonitic fault rocks provide the foundation for a kinematic analysis of the fault movement of the d'Abbadie fault zone. 
SECTION 2 - REGIONAL GEOLOGY 
This section provides the geological setting of the supracrustal rocks and intrusions that are deformed by the d'Abbadie fault zone, and explains how they are situated within the Yukon-Tanana terrane (see Section 2.1), in the Livingstone Creek area (see Section 2.2), and in the study area (see Section 2.3).

\subsection{Yukon-Tanana terrane}

The Yukon-Tanana terrane is a northwest-southeast trending pericratonic terrane (Colpron et al. 2006, 2007) that extends from east-central Alaska, to Yukon and northern British-Columbia (Fig. 3). In map view, it is bounded by the Insular terranes to the west and Ancestral North America to the east (Fig. 3). In south-central Yukon, it is bounded by Quesnellia (part of Intermontane terrane) to the west and Cassiar terrane (part of ancestral North America) to the east (Fig. 4). Prior to Colpron (2006b), the eastern boundary of Yukon-Tanana terrane had been interpreted to coincide with the d'Abbadie fault zone (Tempelman-Kluit 1979, 1984; Hansen 1989; Hansen et al. 1989; 1991). However, de Keijzer et al. (1999), de Keijzer (2000), Harvey $(1996,1997)$, Gallagher (1999) and Colpron (2005a) showed that the fault was not a terrane boundary. The d'Abbadie fault zone is a strike-slip fault (Harvey et al. 1996, 1997; Gallagher 1999; Colpron 2005a) within the Yukon-Tanana terrane rocks (Colpron 2006b), and the terrane boundary is located approximately 20 kilometres to the east of the d'Abbadie fault zone (Westberg et al. 2009; Westberg 2009, 2010).

Supracrustal rocks of the Yukon-Tanana terrane originated from rifted continental fragments, island arcs and back-arc basins that formed between Late 


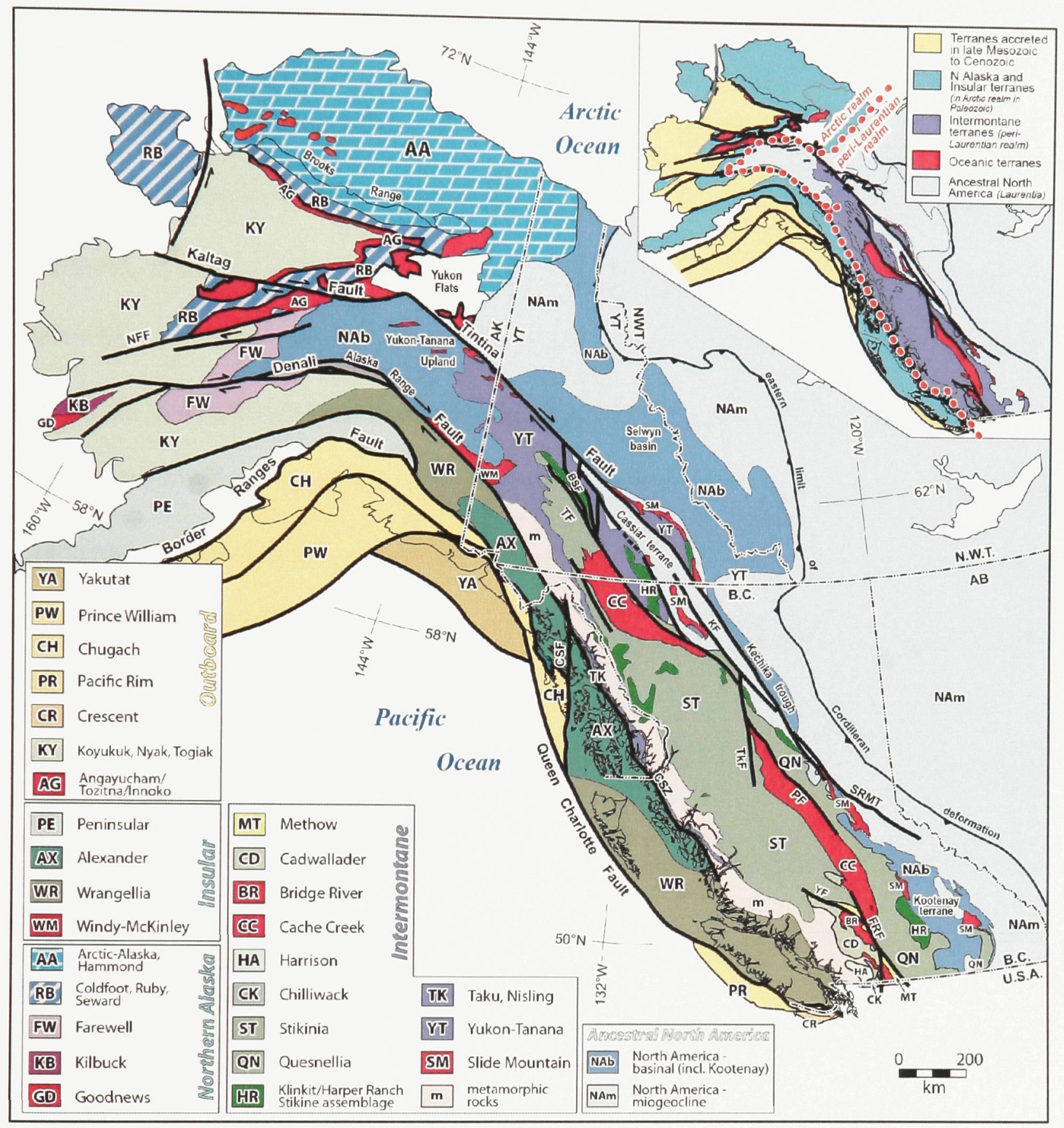

Figure 3

(Colpron et al. 2007)

Figure 3. Terranes of the Cordillera showing the spatial relation of Yukon-Tanana terrane with Insular and Ancestral North America superterranes (after Colpron et al. 2007). 
Devonian and Late Permian time (Mortensen 1992; Colpron et al. 2006a, 2007; Nelson et al. 2006). For the most part, such as in south-central Yukon, these rocks have experienced four and locally five generations of deformation associated with metamorphic events (Colpron et al. 2006a; Berman et al. 2007) between the Late Devonian and Cretaceous. During the Late Devonian to Late Cretaceous these rocks have been intruded by at least five suites of plutonic rocks (Colpron 2006b). Intrusions consist of Late Devonian pre-accretionary plutons, and Jurassic and Cretaceous postaccretionary plutons. Some of the Cretaceous plutons are syn-kinematic with respect to Cretaceous strike-slip faults (Gabrielse et al. 2006). One example of this syn-kinematic relationship is the d'Abbadie fault zone and the Last Peak granite (see Section 2.3). The $d^{\prime}$ Abbadie fault zone in the Yukon-Tanana terrane is a north-striking structure that extends from near Boswell Mountain to $70 \mathrm{~km}$ northward (Fig. 4). Part of the fault zone is located along the eastern edge of the Livingstone Creek area which is described below.

\subsection{Geology of Livingstone Creek area}

In the Livingstone Creek area (NTS 105E/8), polydeformed rocks of the YukonTanana terrane consist of five successions of Late Devonian and older (?) to Mississippian and younger (?) metasedimentary and metavolcanic rocks (Colpron 2005a, $b, 2006 b$ ). These include the Snowcap complex (Colpron 2005a, b), and the Livingstone Creek (Colpron 2005a, b), Mendocina Creek (Colpron 2005a, b; Westberg et al. 2009; Westberg 2010), Last Peak (Harvey et al. 1997; Colpron 2005a, b) and Dycer Creek (Gallagher 1999; Colpron 2005a, b) successions (Fig. 5). The Snowcap complex is 
Figure 4. Simplified terrane map showing the spatial relation of the d'Abbadie fault zone with the Yukon-Tanana terrane, Cretaceous plutonic suites and the Teslin fault (after Colpron 2011). The red box delineates the location of the Livingstone Creek area (NTS 105E/8) shown by Figure 5 . 


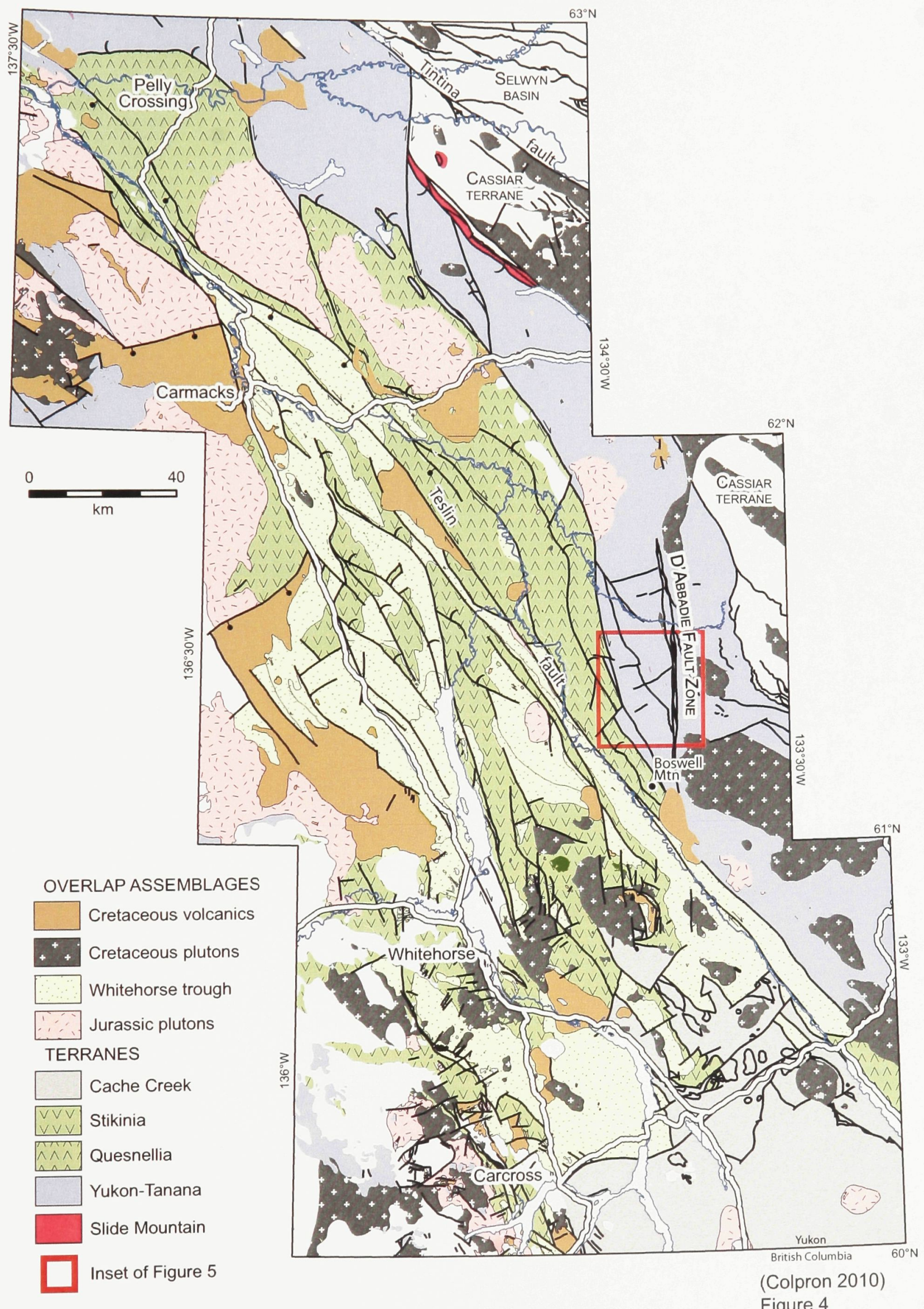

Figure 4 
Figure 5. Simplified geology map of the Livingstone Creek area (NTS 105E/8) (after Colpron 2005a) illustrating the cross-cutting relationship between the dextral strike-slip d'Abbadie fault zone and the trend of structures in the supracrustal rocks. The box indicates the location of the study area shown in Figure 6. Refer to Colpron 2005a for the Table of assay samples. 


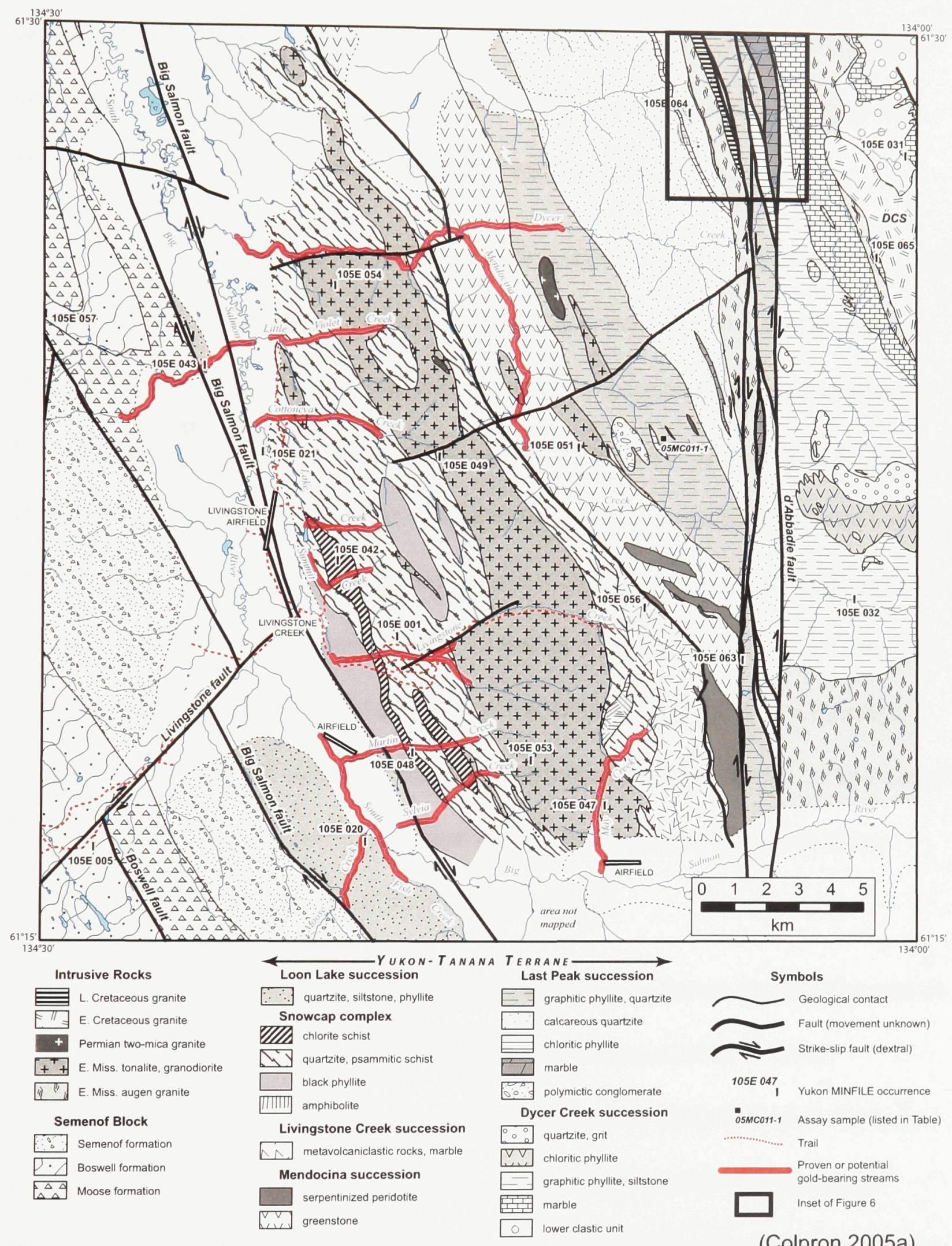

Figure 5 
predominantly composed of quartzite and psammitic schist; the Livingstone Creek succession includes mostly metavolcaniclastic rocks and marble; and the Mendocina Creek succession consists of greenstone with serpentinized peridotite. The Last Peak and Dycer Creek successions are described in Section 2.3 below.

Rocks in the Livingstone Creek area have undergone four (Gallagher 1999) or five (de Keijzer 2000) generations of penetrative folding, three of which have penetrative axial planar foliations (de Keijzer 2000). The rocks are characterized by a pervasive transposition foliation that is concordant with the compositional layering and lithologic contacts. The transposition foliation is axial planar to tight or isoclinal folds and contains metamorphic minerals that are concordant with (Colpron 2005a) and formed earlier than or during the transposition foliation. To the west of the d'Abbadie fault zone, the transposition foliation and isoclinals folds control the map pattern, where lithologic contacts are concordant with the transposition foliation (Colpron 2006b). To the east of the d'Abbadie fault zone, the map pattern is controlled by the interference of two phases of non-coaxial to isoclinals folds (Colpron 2006b).

Metamorphism in the area generally occurred in the Permo-Triassic (Berman et al. 2007). The rocks were metamorphosed under upper greenschist to lower amphibolites facies conditions (Hansen 1989; Stevens et al. 1996; Gallagher 1999; de Keijzer 2000), based on qualitative analyses of metamorphic mineral assemblages throughout the area. ${ }^{40} \mathrm{Ar} /{ }^{39} \mathrm{Ar}$ thermochronology studies on muscovites in rocks in the vicinity of the d'Abbadie fault zone and westward to the Big Salmon fault (Hansen et al. 
1989, 1991; unpublished data by M. Colpron 2005) yield ages of ca. 191-195 Ma, and indicate that the rocks cooled in Early Jurassic. Other ${ }^{40} \mathrm{Ar} /{ }^{39} \mathrm{Ar}$ thermochronology studies on muscovites near the d'Abbadie fault (Hansen et al. 1989, 1991) vield ages of ca. $97 \mathrm{Ma}$, which is indicative of a local mid-Cretaceous activity and cooling along the d'Abbadie fault zone.

Several Mississippian plutons intruded the rocks of the region such as the Mendocina orthogneiss. Jurassic and mid-Cretaceous plutons include the Dycer Creek stock and the Last Peak granite. At the eastern edge of the Livingstone Creek area (Fig. 5), supracrustal rocks are truncated by the d'Abbadie fault zone. On the basis of detailed geological and structural mapping, Gallagher (1999) correlated structures on both sides of the d'Abbadie fault zone and determined that they underwent the same deformation history. This interpretation is consistent with that of de Keijzer (2000) who worked 10$15 \mathrm{~km}$ to the north; he proposed that rocks on both side of the fault were deformed as a result of pre- to syn-peak metamorphic shearing in the middle Early Permian and late Middle Triassic.

\subsection{Geology of a transect across the d'Abbadie fault zone}

This study focuses on a detailed examination of the d'Abbadie fault in part of a transect in the Livingstone Creek area (Fig. 5). Rocks within the transect studied (Fig. 6) include upper greenschist facies metasedimentary and metavolcanic supracrustal rocks of the Last Peak and Dycer Creek successions, the Last Peak granite and the Mendocina orthogneiss (Harvey et al. 1996, 1997; Gallagher 1999; Colpron 2005a, b, 2006b; this study). 


\section{Legend}

\section{Lithology \\ Intrusive rocks}

LGP Last Peak granite (U/Pb monazite, $96 \pm 1 \mathrm{Ma}$; Gallagher 1999)

MO Mendocina orthogneiss (U/Pb zircon, $358 \pm 1$ Ma; Gallagher 1999)

\section{Last Peak succession}

A Dolomitic marble interlayered with argilite

B. Chl schist

C Chl-Bt psammite

D Dolomitic marble

E Graphite-bearing Ms phyllite interlayered and Ms schist

F Quartzite interlayered with Bt-Ms phyllite

G Ms-Chl schist interlayered with dolomitic phyllite

\section{Dycer Creek succession}

$\mathrm{H}$ White marble

I Calcareous Bt-schist with Qtz-carbonate layers

\section{Structure}

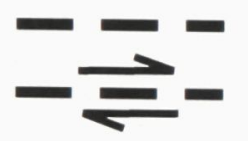

fault, sense of displacement uncertain

fault with known sense of displacement

- _ _ f fold generation 1 (trace of fold axial plane)

-. - - - fold generation 2 (trace of fold axial plane)

Contacts

shear foliation $\left(S_{\text {my } 2}, L P G\right)$

shear foliation $\left(\mathrm{S}_{\mathrm{my} 1}, \mathrm{MO}\right)$

.............. inferred

-ーーー- approximate

transposition foliation $\left(\mathrm{S}_{\mathrm{t} 2}\right)$

Figure 6. Geological map of a transect across d'Abbadie fault zone, located near the northeastern corner of the Livingstone Creek area (Fig. 5). Map units consist of midPaleozoic metasedimentary and metavolcanic rocks of the Last Peak (Harvey et al. 1997) and Dycer Creek successions (Gallagher 1999), in the Yukon-Tanana terrane. Meta-igneous rocks consist of the Early Mississippian Mendocina orthogneiss and the mid-Cretaceous Last Peak granite. Chl - chlorite, $\mathrm{Bt}$ - biotite, Ms - muscovite. 


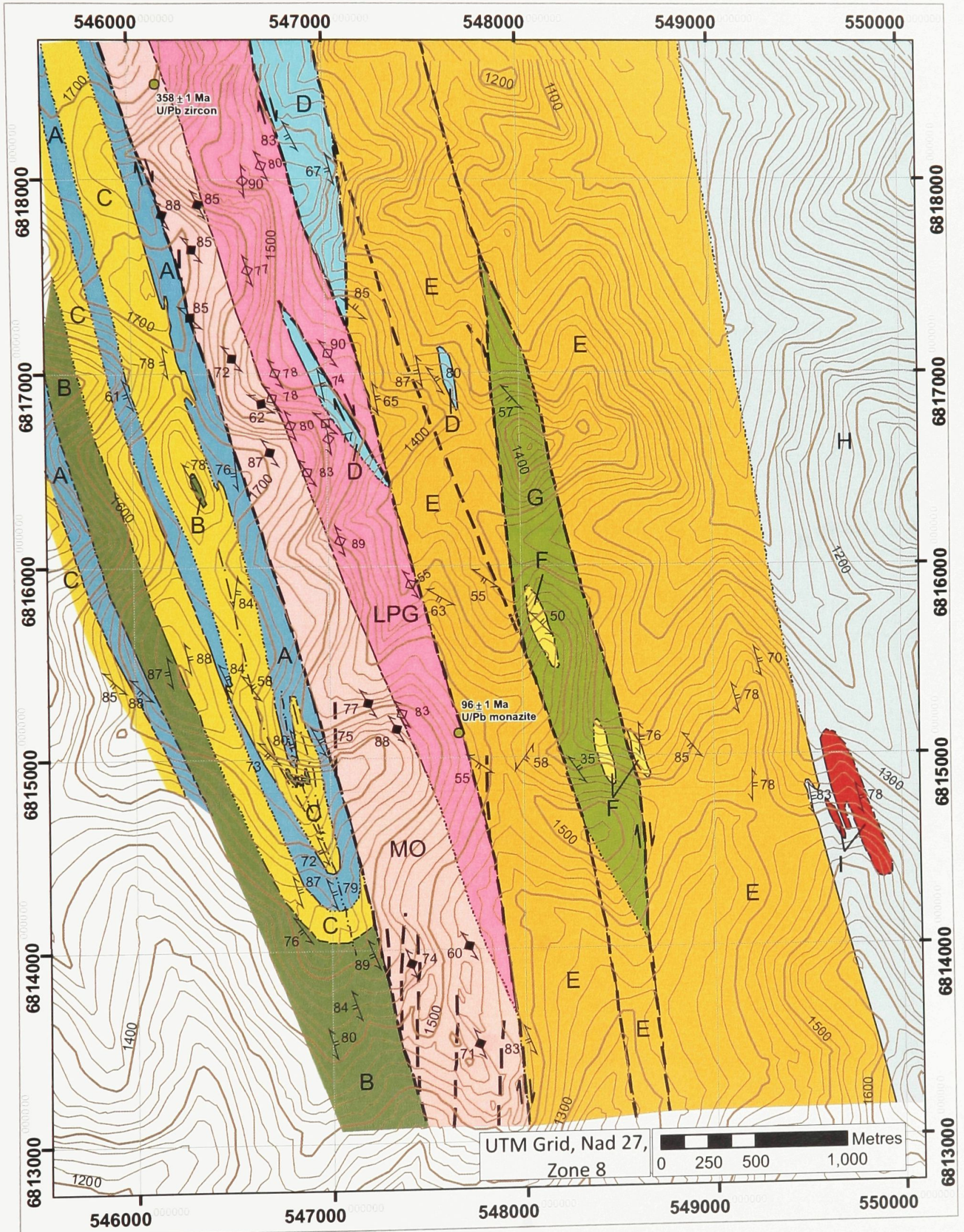

Figure 6 
Figure 7. Mesoscopic view of representative supracrustal rocks and intrusive rocks adjacent to the d'Abbadie fault zone. (a) Steep face of an interlayered argillite-dolomitic marble with polyphase folding from the Last Peak succession (map unit A in Figure 6). The upper greenschist-facies regional foliation has experienced at least 4 phases of folding. Note the hook interference pattern. (b) Southward view of steeply-dipping penetrative $\mathrm{S}_{\mathrm{t} 2}$ foliation in a calcareous biotite schist interlayered with light coloured, 1 to $30 \mathrm{~cm}$-thick marble of the Dycer Creek succession (map unit I in Figure 6). (c) Pavement view of folded mylonitic Kfeldspar augen Mendocina orthogneiss, looking at the motion plane, parallel to the stretching lineation and perpendicular to the steeply dipping shear foliation (C-plane). Note that such folding is absent in the Last Peak granite. 

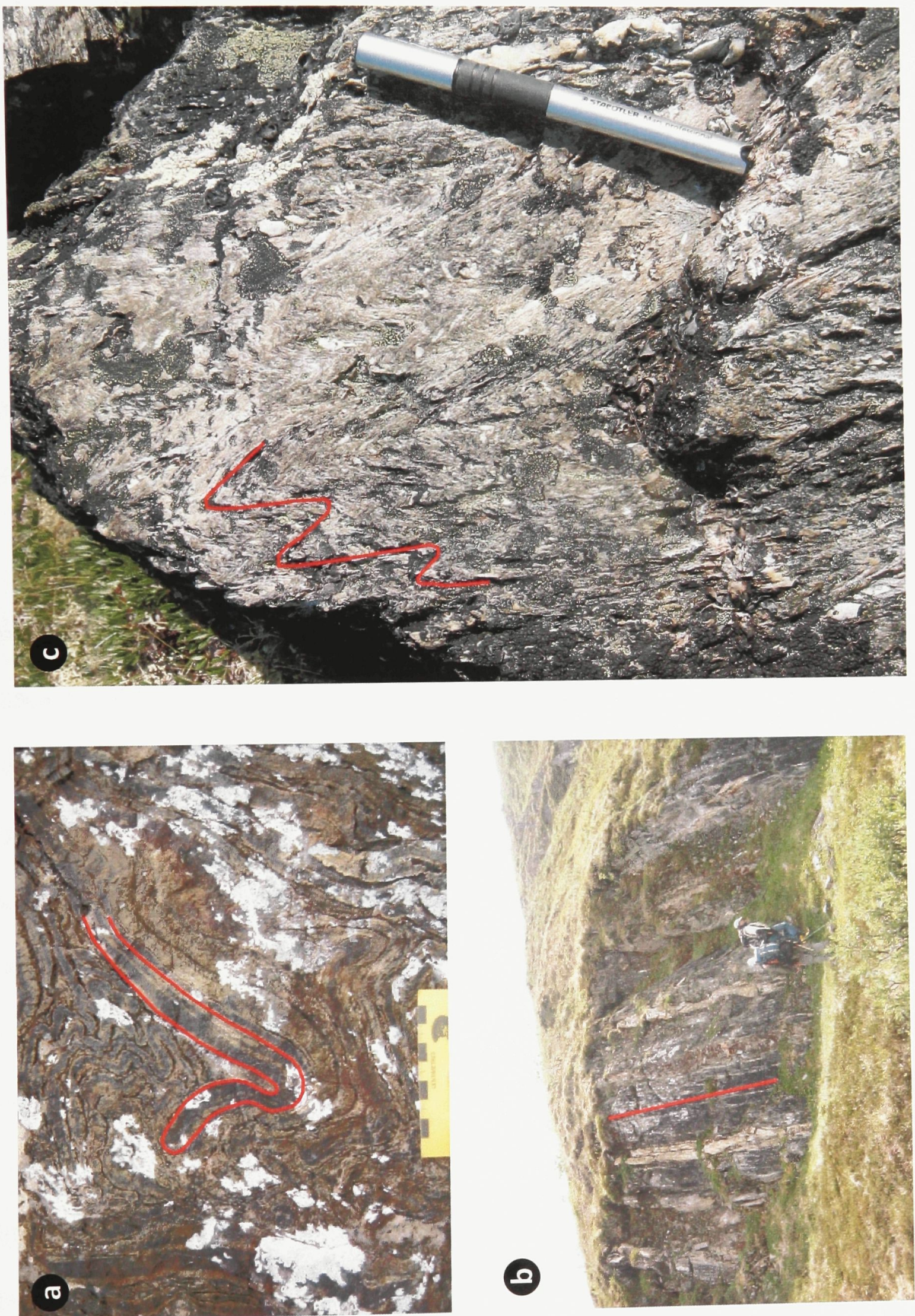

峁 
The Last Peak succession occurs on both sides of and within the d'Abbadie fault zone. It includes dolomitic marble interlayered with argillite (Fig. 7a), chlorite schist, chlorite-biotite psammite, dolomitic marble, quartzite interlayered with biotitemuscovite phyllite, graphitic to graphite-bearing muscovite phyllite and muscovite schist. The Dycer Creek succession occurs east of the fault zone and consists of white marble and calcareous biotite schist with quartz-carbonate interlayers (Fig. 7b). Details of lithology and mineralogy are summarized in Table 1; descriptions are based on lithological descriptions and successions defined by Harvey et al. (1996, 1997), Gallagher (1999) and Colpron $(2005 a, b)$, and combined with field observations.

Supracrustal rocks like the Last Peak succession have a complex structural and metamorphic history that predated the d'Abbadie fault zone and it is important to define this history before interpreting the structures associated with the d'Abbadie fault zone. The rocks are polydeformed and marked by a penetrative transposition foliation. As previously defined by Gallagher (1999) and de Keijzer (2000), this transposition foliation comprises lithologic contacts, concordant compositional layers, and rootless folds. Because the history of deformation events predating $\mathrm{S}_{\mathrm{t} 2}$ is uncertain, the transposition foliation is referred to as " $\mathrm{S}_{\mathrm{t} 2}$ ". In the study area, $\mathrm{S}_{\mathrm{t} 2}$ is northwestsoutheast striking and generally dips steeply westward to the west of and within the d'Abbadie fault zone. To the east of the d'Abbadie fault zone, $\mathrm{S}_{\mathrm{t} 2}$ dips moderately $\left(30^{\circ}\right.$ $60^{\circ}$ ) to the west. $S_{t 2}$ is concordant with the traces of axial planes of $F_{1}$ and $F_{2}$ folds (Fig. 6). The steep arrangement of the rocks is controlled by $F_{3}$ folding (de Keijzer 2000; 


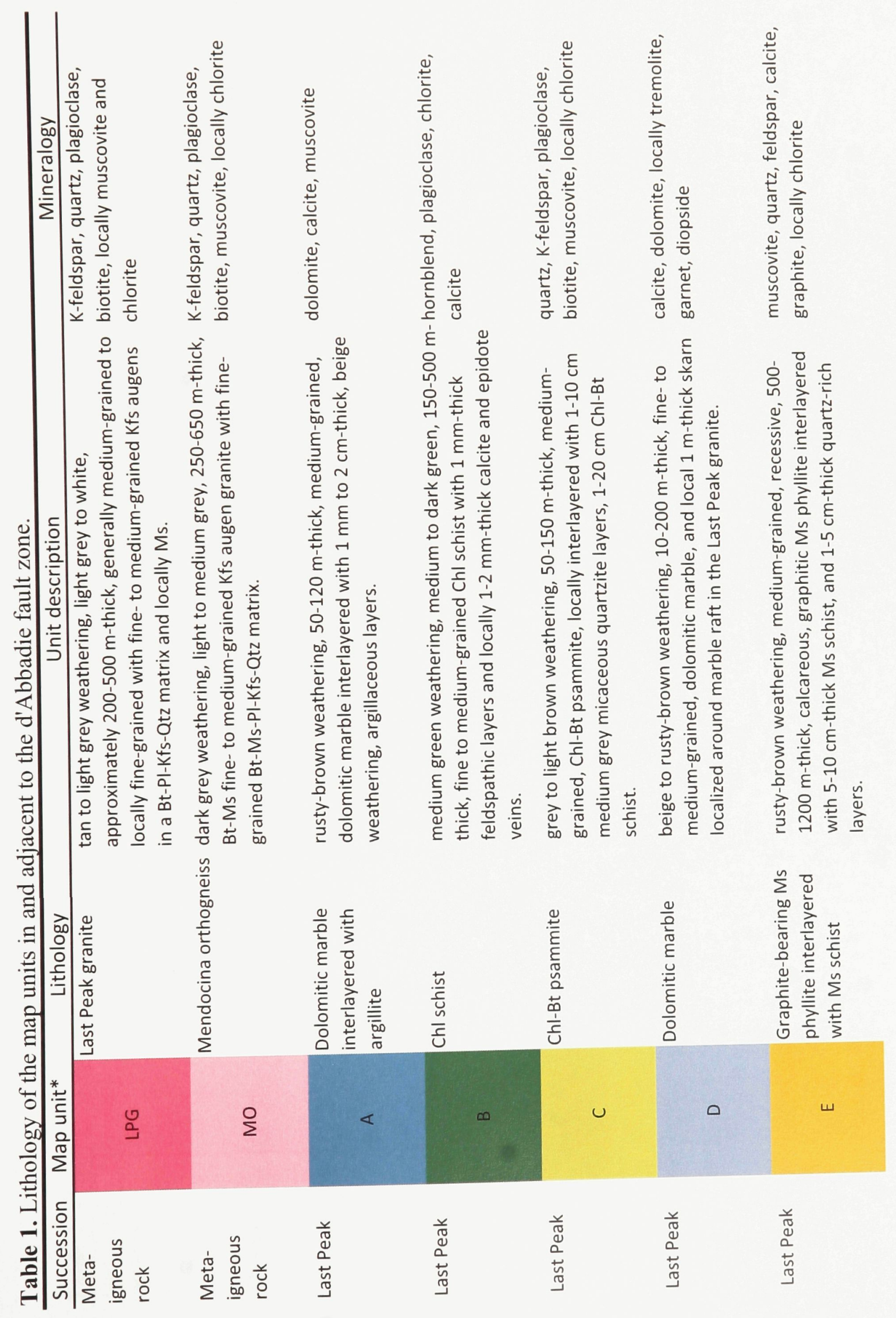




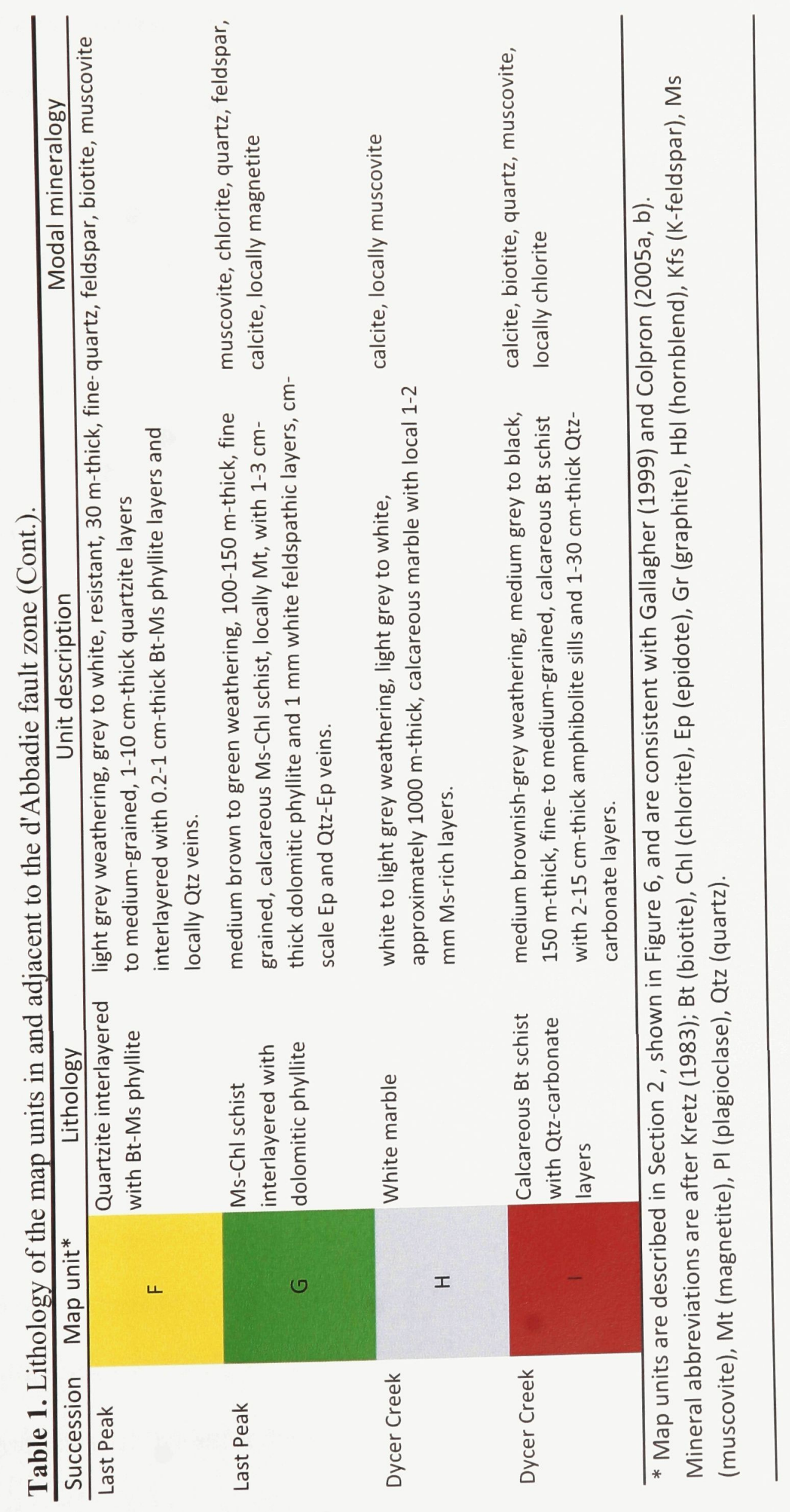


Gallagher 1999). The map pattern is primarily controlled by the penetrative transposition foliation that is concordant with the lithologic contacts and compositional layering, and by north and south verging, steeply dipping $F_{3}$ folds that folded $S_{\mathrm{t} 2}$ (Fig. 6).

The oldest meta-igneous rock in the area is the Early Mississippian Mendocina orthogneiss (ca. $358 \mathrm{Ma}$; Gallagher 1999). Another prominent meta-igneous rock consist of the mid-Cretaceous Last Peak granite (ca. 96 Ma; Gallagher 1999). Although determination of the structural history of the Mendocina orthogneiss is beyond the scope of this study, lithological observations and preliminary structural observations are presented below.

\subsubsection{Mendocina orthogneiss}

The Mendocina orthogneiss is a NW-SE trending, steeply dipping, 250-650 mthick sheet that extends the length of the study area and is generally concordant with the foliation in the hosting rocks of the Last Peak succession. It is a dark grey weathering, light to medium grey, biotite-muscovite-rich K-feldspar augen orthogneiss, and its protolith is interpreted to have been a two-mica granite. The matrix is composed of very fine- to fine-grained biotite, muscovite, $\mathrm{K}$-feldspar, plagioclase, quartz and locally medium-grained biotite. The Mendocina orthogneiss is strongly foliated and lineated. It has a steeply dipping and NW-SE striking mylonitic foliation and quartz stretching lineation shallowly plunging to the NW or SE. Although the Mendocina orthogneiss had been recognized in the early stages of mapping in the area (Tempelman-Kluit 1979, 1984; Hansen 1989), it was interpreted to form one body with the Last Peak granite. It is notable that the Mendocina orthogneiss is folded (Fig. 7c). Although the deformation 
history of the Mendocina orthogneiss and its significance is uncertain, it is interpreted to have a more complex deformation history in comparison to the Last Peak granite based on preliminary observation of folds. The mylonitic foliation in the Mendocina orthogneiss can be referred to as $S_{m y 1}$, where " $m y$ " refers to mylonitic folitation and "1" for the generation. Any mylonitic foliation cutting across $S_{m y 1}$ would be $S_{m y 2}, S_{m y 3} \ldots S_{m y n}$. The relation or difference between $\mathrm{S}_{\mathrm{t} 2}$ and $\mathrm{S}_{\mathrm{my} 1}$ is unclear as work on the Mendocina orthogneiss for this study was only minimal. Complex folding of $S_{m y 1}$ in the Mendocina orthogneiss poses the question of whether the folds are concordant with the ones in the supracrustal rocks or not. For the purpose of this study, $\mathrm{S}_{\mathrm{t} 2}$ is considered to have formed before $\mathrm{S}_{\mathrm{my} 1} . \mathrm{S}_{\mathrm{my} 1}$ and folds in the Mendocina orthogneiss did not develop in the d'Abbadie fault zone. ${ }^{40} \mathrm{Ar} /{ }^{39} \mathrm{Ar}$ themochronology of muscovite in the Mendocina orthogneiss yield an age of $97 \pm 1$ Ma (see Appendix for the details; this study).

\subsubsection{Last Peak granite}

The Last Peak granite is a NW-SE striking, steeply dipping and approximately 200500 m-thick plutonic sheet that lies within the central part of the study area (Fig. 6). It extends northward for $12 \mathrm{~km}$ along strike to Last Peak in the Teraktu Creek area (NTS 105E/9).

\section{Petrography}

The Last Peak granite is tan to light grey weathering (Fig. 8a), light grey to white, generally medium-grained and locally fine-grained with fine- to medium-grained K- 
Figure 8. Mesoscopic views of the Last Peak granite. (a) Southward view of the Last Peak granite from the Ultramylonite domain with a penetrative and steeply dipping mylonitic foliation (red line; C-plane). Hammer for scale. (b) K-feldspar porphyroclast with minor pressure shadows in a protomylonite from the Protomylonite domain in the Last Peak granite. Note the trace of the C-plane (red line). 

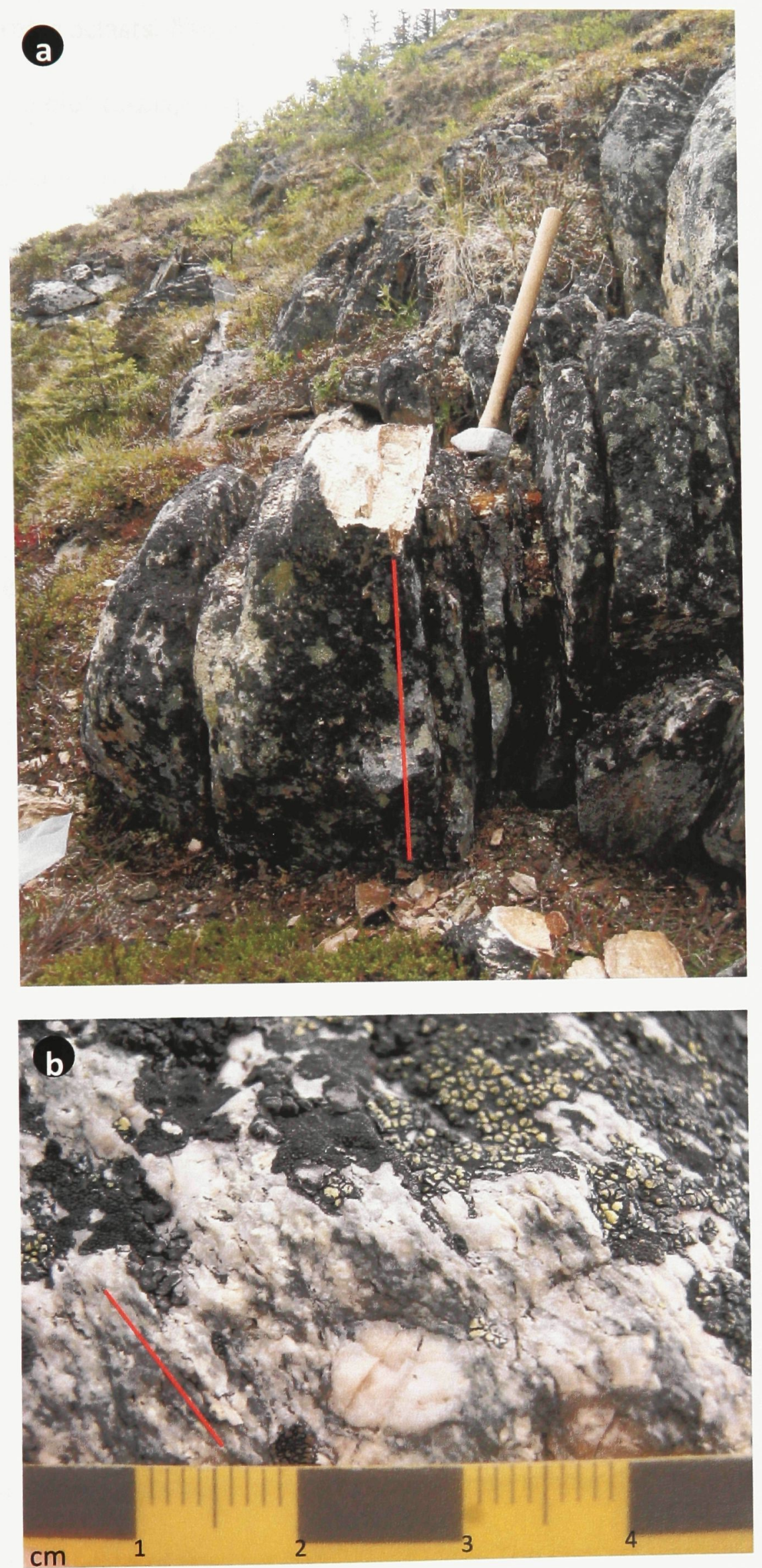

Figure 8 
feldspar porphyroclasts. These porphyroclasts are 0.5 to $2 \mathrm{~cm}$ long (Fig. 8 b) and are contained in a biotite-plagioclase-K-feldspar-quartz matrix, with local muscovite. The modal mineralogy and presence of relict porphyritic texture supports the interpretation that the rock is igneous in origin and that the protolith is a leucogranite. The presence of a mylonitic foliation defined by elongate porphyroclasts with pressure shadows, flattened quartz and preferred alignment of biotite crystals, and a quartz-stretching lineation indicates that the granite has been deformed and recrystallized. U/Pb geochronology of igneous monazites with defined zoning from the Last Peak granite yielded a crystallization age of $96 \pm 1 \mathrm{Ma}$ (Gallagher 1999).

\section{Contact relationships}

The Last Peak granite in the study area is bounded to the west by the Mendocina orthogneiss (Fig. 6). Harvey et al. $(1996,1997)$ interpreted the western contact, to the north of Livingstone Creek (in the Teraktu map area), as an intrusive contact because of the occurrence of undeformed apophyses of the Last Peak granite, with chilled margins and aplite dikes cross-cutting the composite foliation $\mathrm{S}_{\mathrm{t} 2}$ in the supracrustal rocks. Similarly, the Last Peak granite's contact and mylonitic foliation sharply cross-cut the more penetratively foliated Mendocina orthogneiss (Fig. 9). This is consistent with the interpretation of an intrusive relationship, and indicates that the nature of the contact is consistent along its $12 \mathrm{~km}$ length.

The eastern contact of the Last Peak granite is bounded by a dolomitic marble and graphitic phyllite of the Last Peak succession. The contact was not observed; however, the contact between the granite and a marble raft within the granite was 


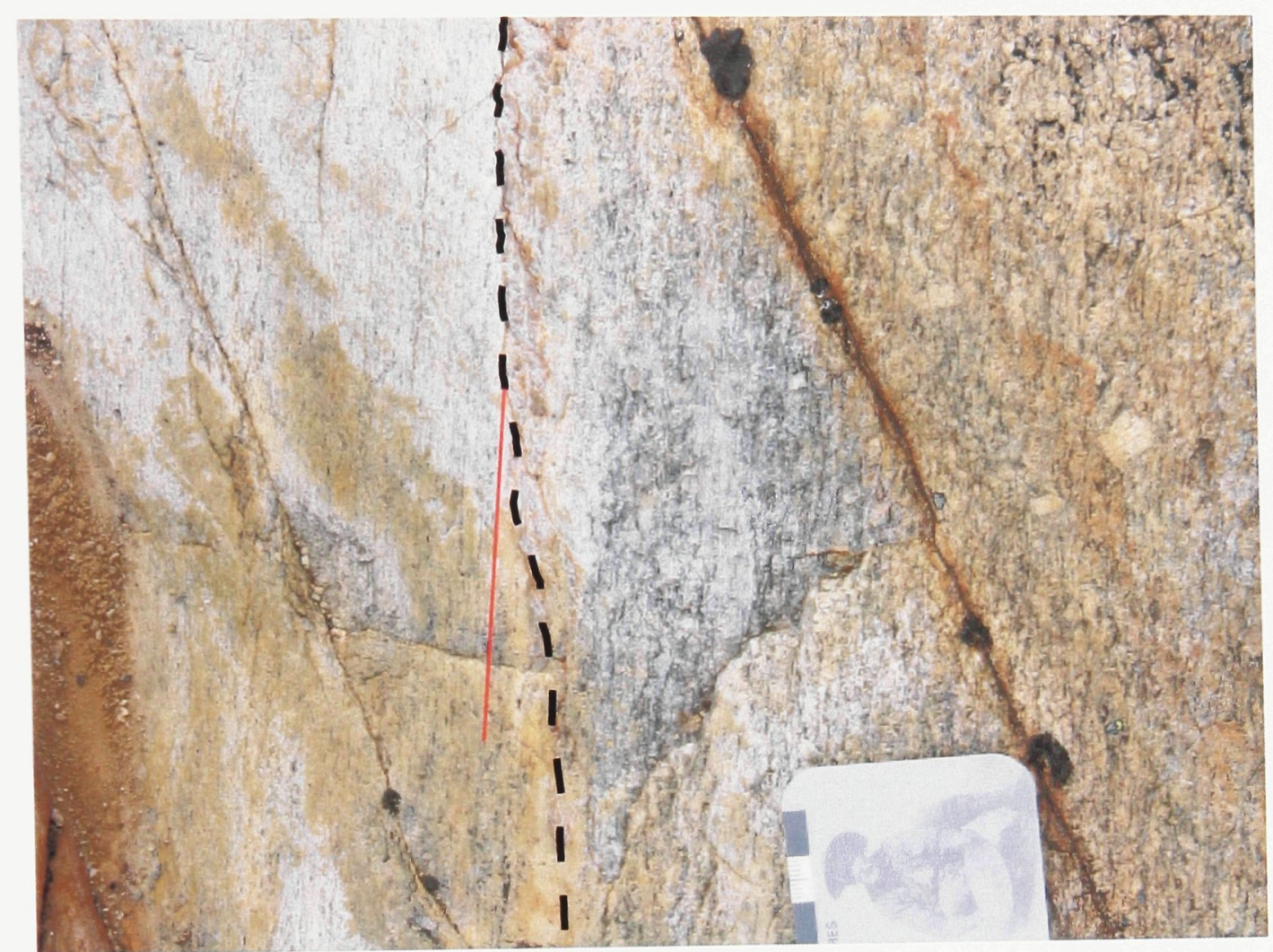

Figure 9. Photograph of the contact between the Mendocina orthogneiss and the Last Peak granite. Pavement view looking down on the steep and sharp intrusive contact (dashed line) between the Last Peak granite (right) that cross cuts $S_{\text {my1 }}$ (red line) of the Mendocina orthogneiss (left) (picture taken by Colpron 2005a). 
mapped. The western side of the raft consists of approximately $1 \mathrm{~m}$ contact aureole composed of calcite, garnet, diopside and tremolite. 
SECTION 3 - STRUCTURE OF THE D'ABBADIE FAULT ZONE 
The d'Abbadie fault zone cross cuts steeply dipping, northwest-striking, polydeformed, and low-grade metamorphic rocks of the Last Peak succession, the Mendocina orthogneiss and the Last Peak granite. Although these rocks, together with their internal structures have been documented in the past (Gallagher 1999; de Keijzer 2000; Colpron 2005a; Westberg 2010), this study provides a more detailed documentation of the faults, fault rocks and associated structures directly related to the d'Abbadie fault zone (see Section 3.1).

This study demonstrates that the fault zone is made of multiple strands of variably deformed rocks. Their size, orientation and structural style are defined below (see Section 3.2). In addition, sense of shear indicators were examine as a basis for structural and kinematic analyses (see Section 3.3). The metamorphic conditions of deformation are constrained from the occurrence of metamorphic minerals within the d'Abbadie fault zone (see Section 3.4).

\subsection{Fault rocks in a transect across the d'Abbadie fault zone}

Within the mapped transect, the rock units of the Last Peak succession (to the west of the Mendocina orthogneiss) and their internal contacts are moderately exposed, continuous and can be traced along strike along alpine ridges (Fig. 6). In contrast, the rocks in the d'Abbadie fault zone are moderately exposed (Fig. 10a) on rolling hills (Fig. 10b). They are primarily affected by brittle and cataclastic structures, and locally mylonitic structures. 
Figure 10. (a) Map showing outcrop control in the d'Abbadie fault zone. The amount of rock exposure increases from east to west across the fault zone. (b) Photograph looking to the northeast, across strike, at the style of exposure in the d'Abbadie fault zone at the latitude of $61^{\circ} 28^{\prime} 45^{\prime \prime} \mathrm{N}$. Dashed lines indicates the approximate margins of the fault zone. Beigecoloured outcrops are sparse and consist of brittlely deformed Paleozoic supracrustal rocks of the Last Peak succession. 

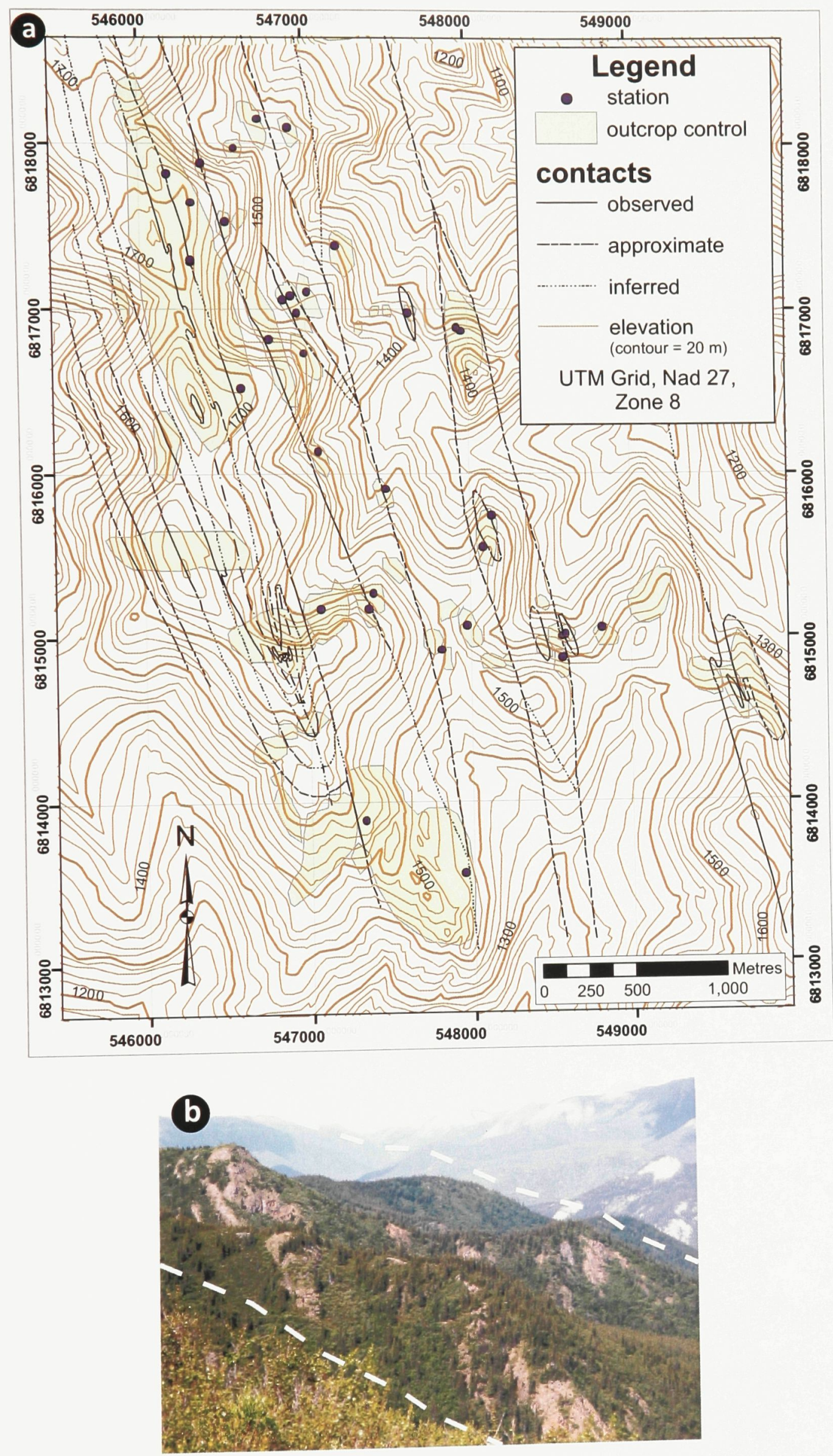

Figure 10 
The cataclastic rocks in the fault zone have been classified using Twiss and Moores's (2007) fault rock classification, which is based on the clast sizes and percentage of matrix versus clasts. The breccias are made of 1-500 $\mathrm{mm}$ size clasts in < $30 \%$ matrix. The cataclasites are distinguished from the breccias as they have $>30 \%$ matrix. The cataclasites have been subdivided into cataclasite and ultracataclasite following Davis and Reynolds (1997). The cataclasites are made of $>0.1 \mathrm{~mm}$ to $<10 \mathrm{~mm}$ clasts in $>30 \%$ matrix and ultracataclasites are made of $<0.1 \mathrm{~mm}$ clasts in $>30 \%$ matrix. The fractured rocks have been characterized using nomenclature of Twiss and Moores (2007). Outcrop, hand specimen and/or thin section observations from representative stations in the fault zone are presented in Table 2.

The typical brittle rocks in the d'Abbadie fault, and related structures, are distributed in multiple, variably sized strands throughout the d'Abbadie fault zone and have been classified into different domains including: the Cataclasite, Mixed and Fracture domains (Fig. 11). The domains are named after their dominant structure. The Cataclasite domain occurs as zones of apparently 2-30 m-wide cataclasites. The term "Mixed" refers to the presence of cataclasite, fractures, and locally breccia. Rocks of the Mixed domain occur as zones apparently 50-200 m-wide and are characterized by the sparse distribution of $1 \mathrm{~mm}$ to $40 \mathrm{~cm}$-wide cataclasite zones, $\mathrm{cm}$-scale shear fractures without cataclasite fill, and localized breccias. The Fracture domain occurs as zones apparently 20-500 m-wide and is characterized by the sparse distribution of sets of shear fractures without cataclasite fill. The exact spacing between the sets of fractures is 


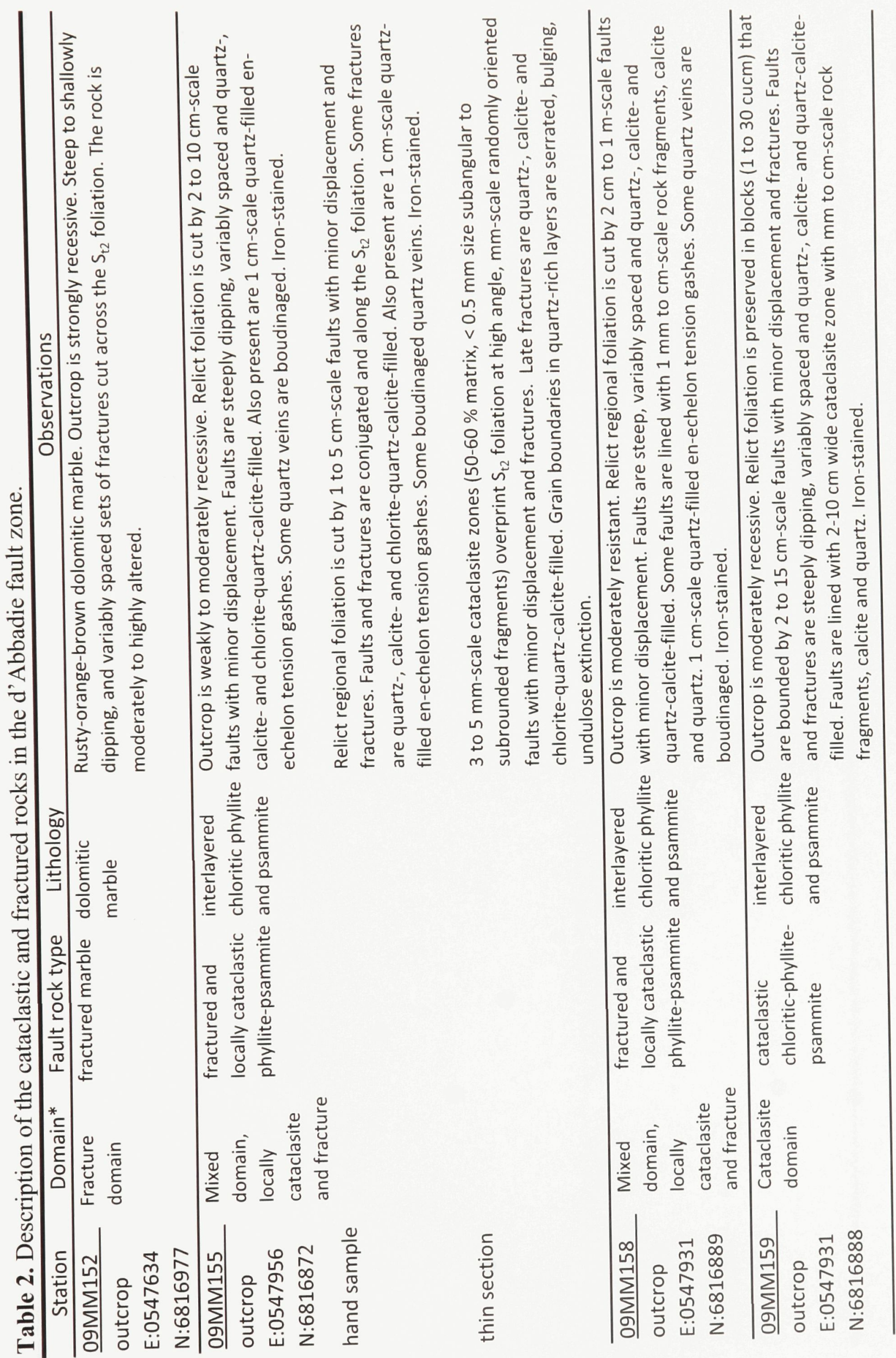



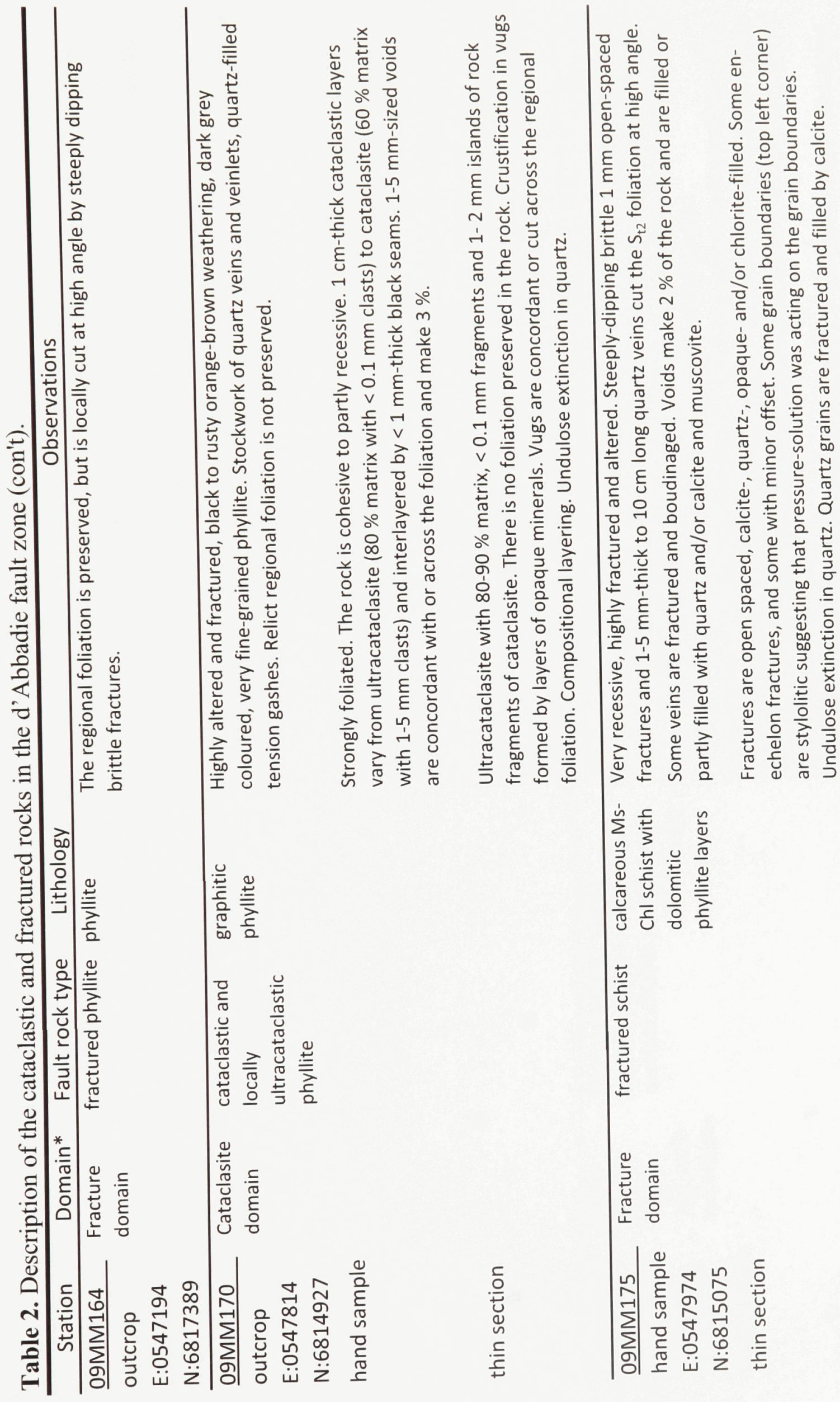


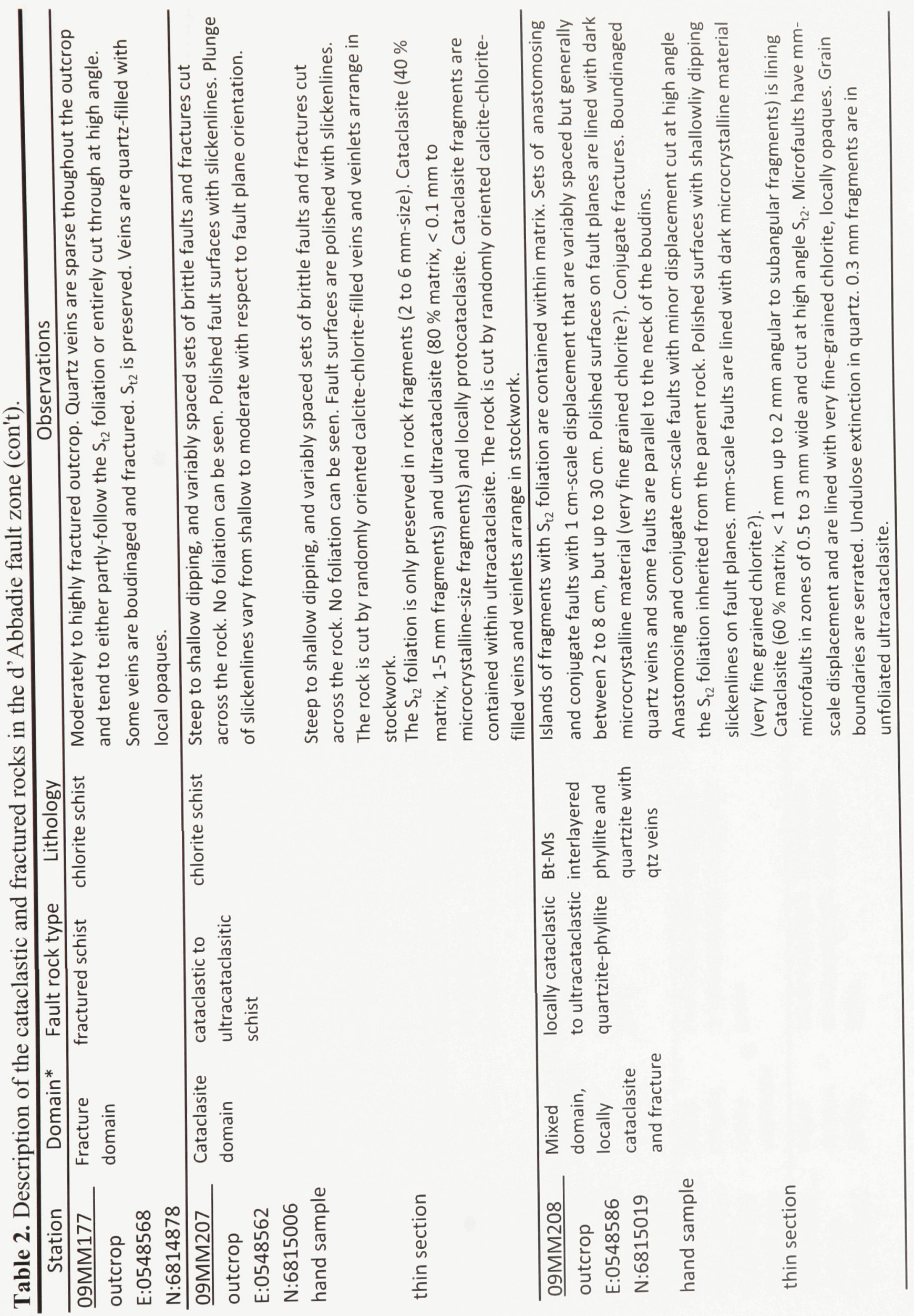




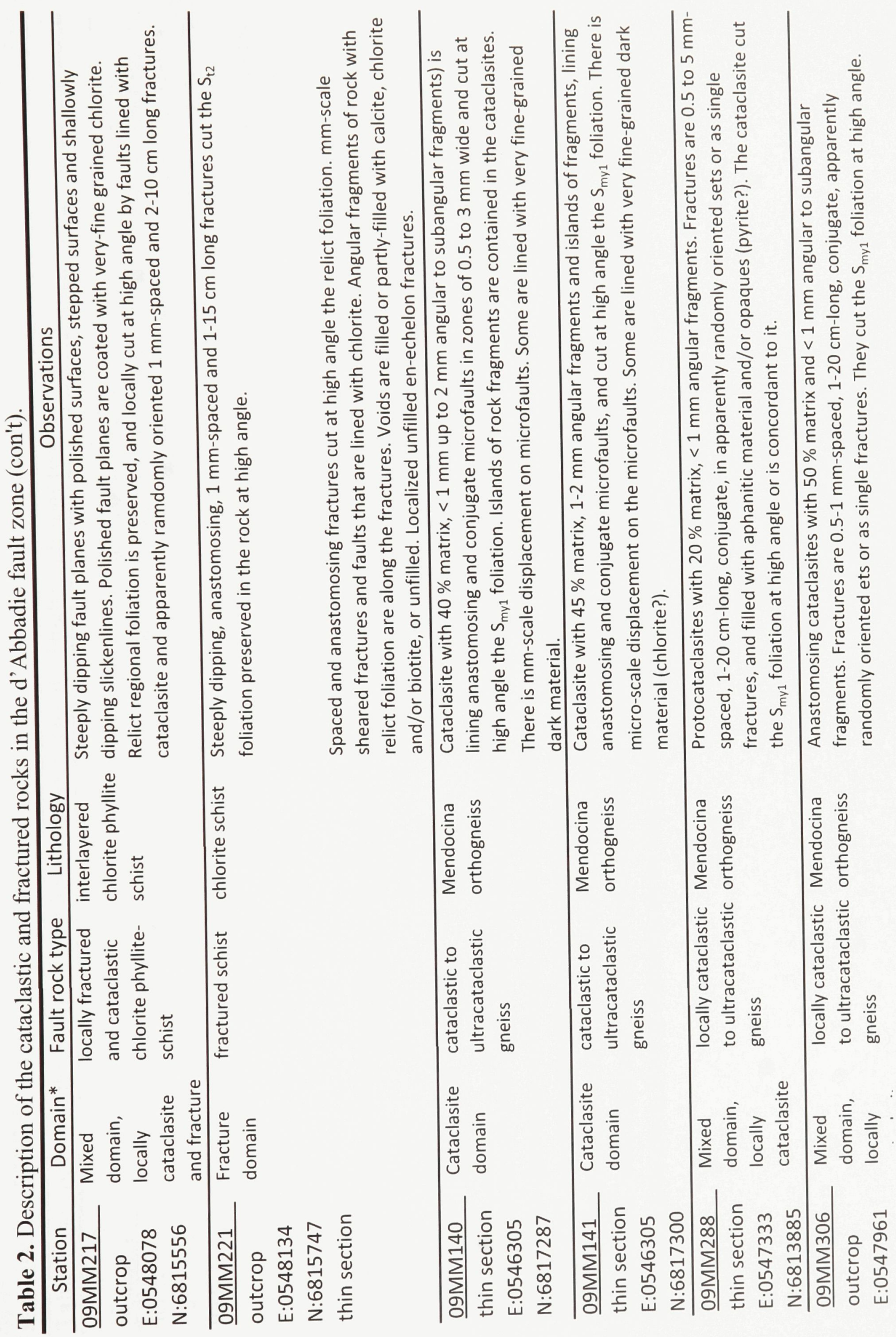




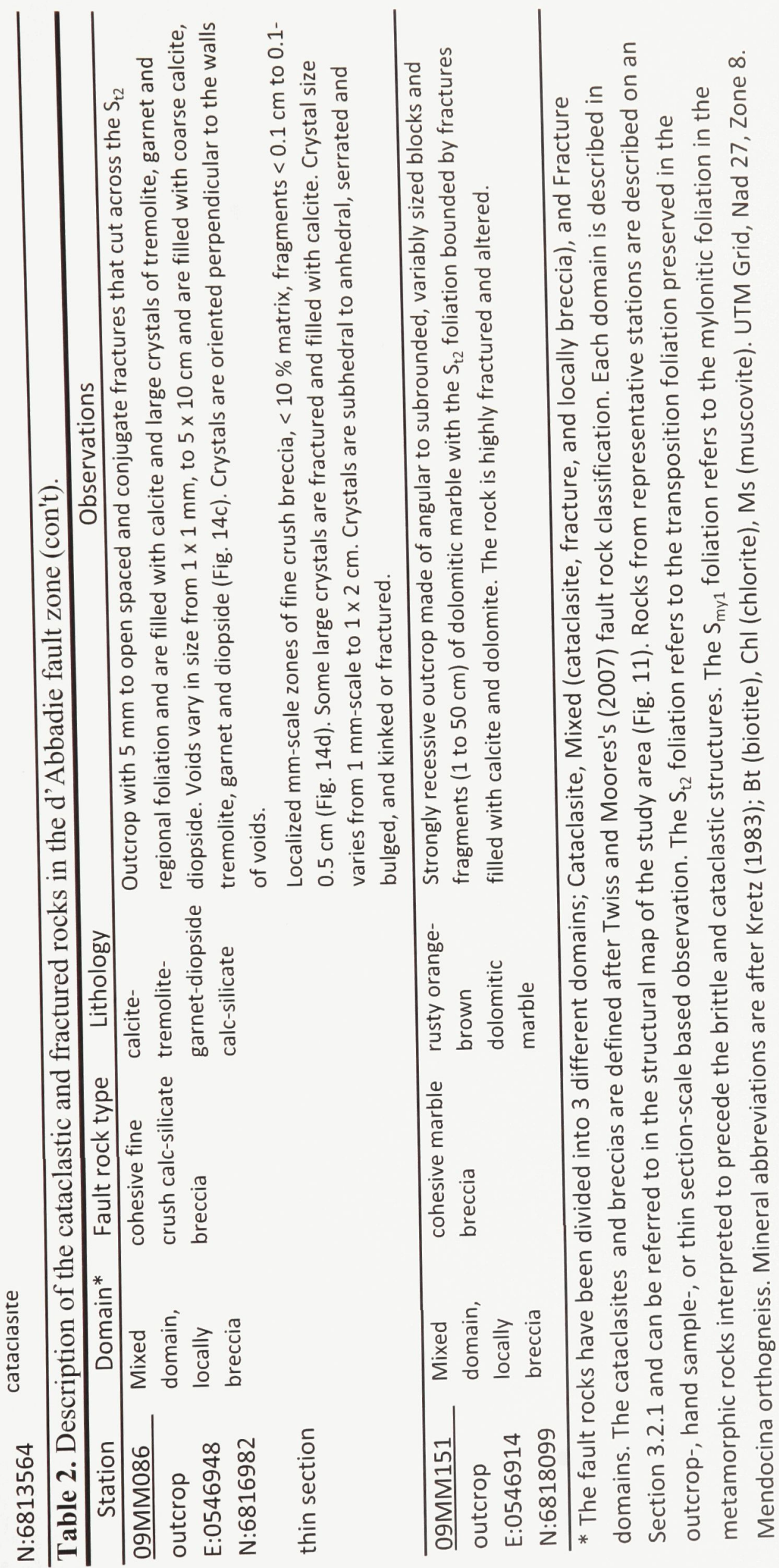




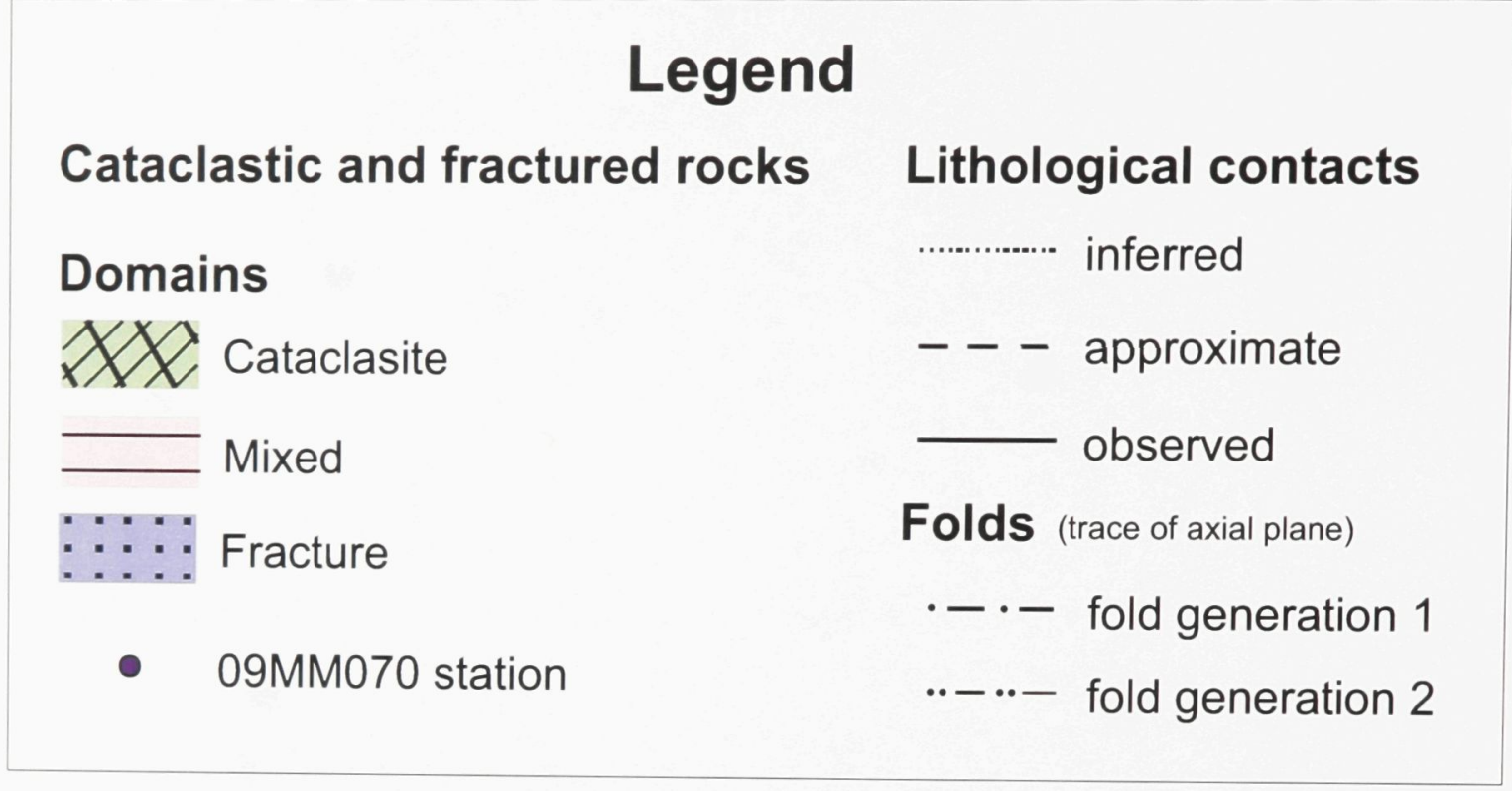

Figure 11. Structural map of the $2 \mathrm{~km}$-thick area of the d'Abbadie fault zone, showing the distribution of cataclastic and fractured rocks according to three domains: Cataclasite; Mixed with locally cataclasites, fractures and breccias; and Fracture domains (see Section 4.2 for explanation). The fault contacts on the map are not exposed but are drawn based on the occurrence of cataclastic fault rocks. Representative stations shown are summarized in Section 3.1.1 and Table 2. 


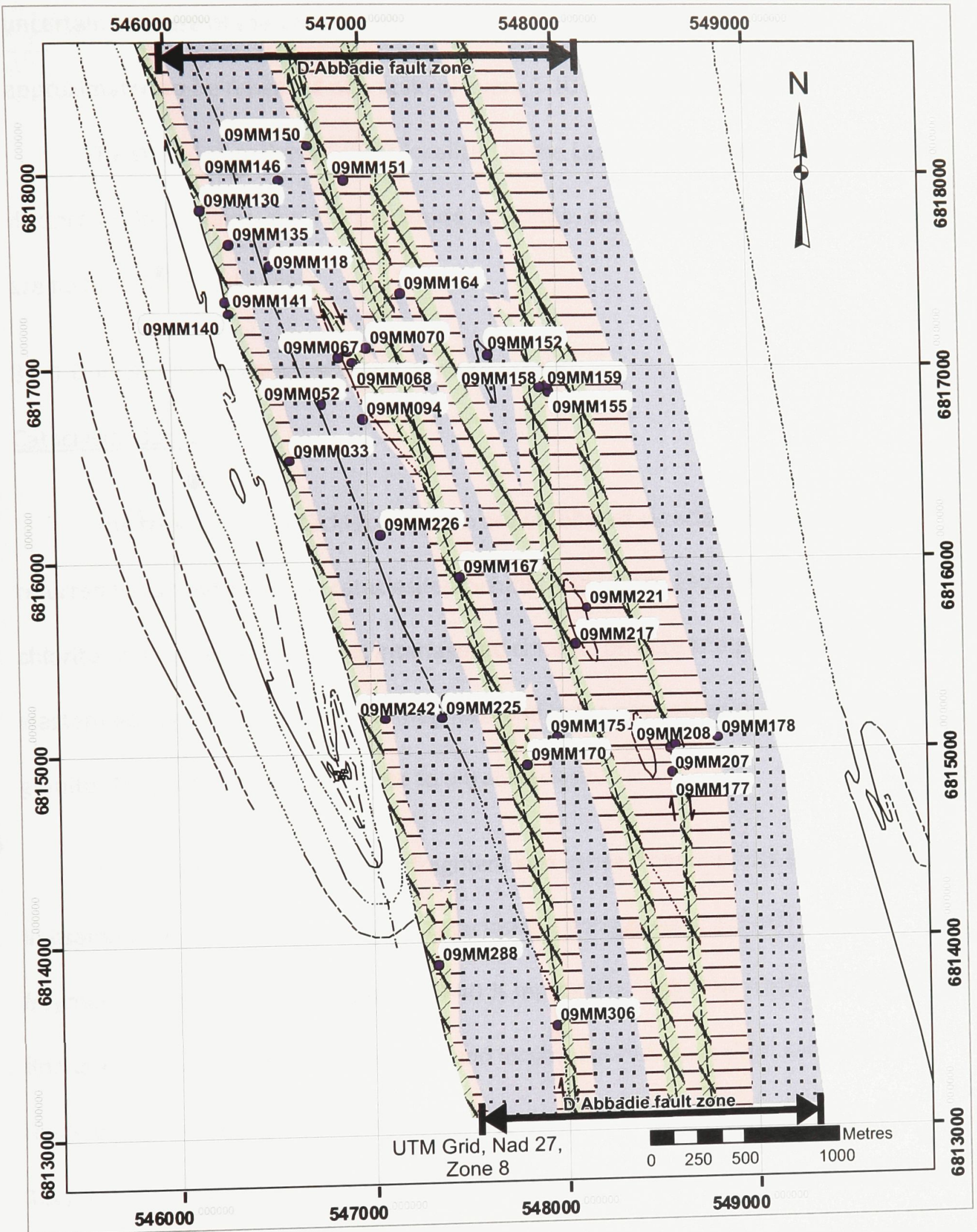

Figure 11 
uncertain because of the poor exposure from one outcrop to the next, but is approximated to be repeated at a scale of every 5-10 $\mathrm{m}$ in each outcrop.

The strand of mylonitic rocks localized in the Last Peak granite is classified into 3 distinct strain domains: the Protomylonite, Mylonite, and Ultramylonite domains. These are further described below.

\subsubsection{Domains in the cataclastic and fractured rocks}

\section{Cataclasite domain}

The rocks in the Cataclasite domain are unfoliated cataclasites (Fig. 12a), also referred to as random fabric cataclasites (Schmid and Handy 1991). They are hosted in chlorite schist, graphitic phyllite, interlayered chloritic phyllite and psammite, in the western edge of the Mendocina orthogneiss and in the eastern edge of the Last Peak granite. They range from cataclasite to ultracataclasite.

Cataclasite composition and fragment size varies from one rock type to the next. In psammite interlayed with phyllite, cataclasite is composed of 1-5 $\mathrm{mm}$ angular fragments that are contained within $30-40 \%$ matrix (Fig. 12b). The matrix is made of fine-grained quartz, biotite, muscovite, and locally chlorite. In phyllite, cataclasite is made of 0.1-3 mm angular fragments that are contained within 50-60\% matrix (Fig. 12c). The matrix is made of fine-grained quartz, biotite, muscovite, locally chlorite and pyrite, and very fine-grained dark material too fine to be distinguished petrographically. Ultracataclasite is made of microcrystalline to $<0.1 \mathrm{~mm}$ angular to subangular fragments that are contained within $80 \%$ matrix (Fig. 12d). Fragment types include 
Figure 12. Representative photographs and photomicrographs of fault rocks from the Cataclasite domain. (a) Southward view of an outcrop of cataclastic chlorite schist. (b) Photomicrograph of cataclastic interlayered chloritic phyllite and psammite. Some rock fragments show evidence of the relict regional foliation, although they have not kept their original orientation - Field of View (FOV) $8 \mathrm{~mm}$ (2.5x), plane polarized light (PPL). (c) Hand sample of alternating cataclasite and ultracataclasite layers in a cataclastic phyllite. (d) Photomicrograph of a layered cataclastic phyllite with randomly orientated and variably sized angular clasts in a very fine-grained matrix - FOV $8 \mathrm{~mm}$, cross polarized light (XPL). (e) Photomicrograph of an ultracataclasite with a cataclastic flow foliation that completely overprinted the regional foliation in a phyllite - FOV $8 \mathrm{~mm}$, PPL. (F) Photomicrograph of vugs with a colloform texture (crustification) within an ultracataclastic phyllite - FOV $2 \mathrm{~mm}$ (10x), PPL. 

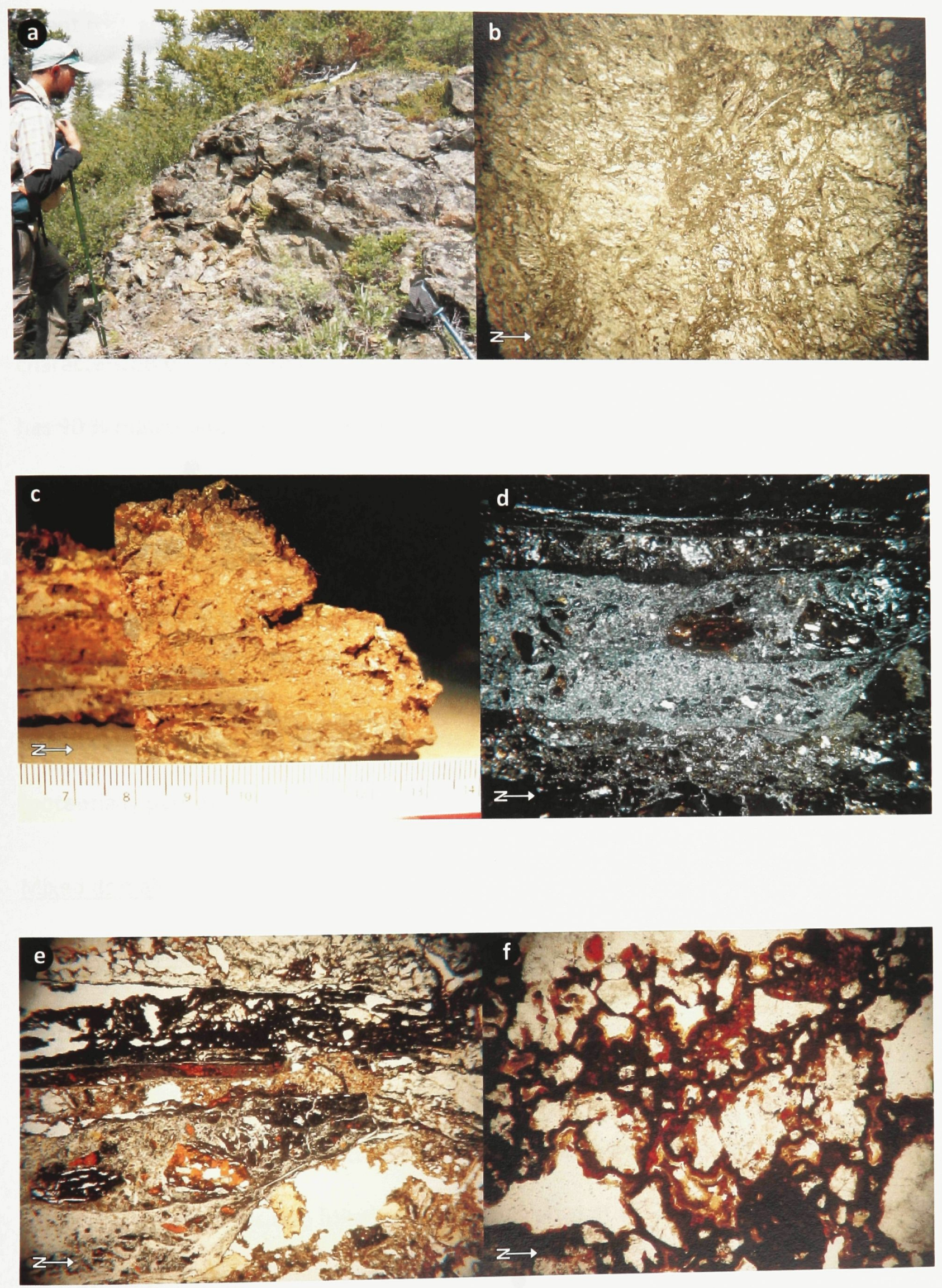

Figure 12 
parent rock and cataclasite. The fragments are generally sharp, angular to subangular, and randomly shaped. The matrix is made of fine-grained quartz, biotite, muscovite, pyrite and chlorite, and aphanitic dark material too fine to be distinguished petrographically.

Ultracataclasite is predominant at Station 09MM170 (Fig. 11), and is characterized by alternating zones of ultracataclasite and cataclasite. Ultracataclasite has $90 \%$ matrix and $<0.1 \mathrm{~mm}$ fragments, and cataclasite has $70-80 \%$ matrix and $1-5$ $\mathrm{mm}$ fragments (Fig. 12e). The matrix is made of very fine-grained quartz, biotite, muscovite, chlorite, pyrite, and aphanitic unidentified dark material. Vugs make up approximately $7 \%$ of the rock volume. They are generally unfilled, but are sometimes partly filled with alternating orange-brown and black layers (Fig. 12f), referred to as crustification (Vernon 2004), of unidentified very fine-grained opaque minerals (potentially pyrite).

\section{Mixed domain}

The Mixed domain is characterized by localized cataclasites, shear fractures, and breccias. The cataclasite is locally found in $1 \mathrm{~mm}$ - to $40 \mathrm{~cm}$-wide zones, within map units E, $F$ and $G$ (Figs. 6 and 13a), that cuts across $S_{t 2}$ at a high angle. In contrast, within the Cataclasite domain, brittle structures in the Mixed domain are confined to discrete zones and the transposition foliation $\mathrm{S}_{\mathrm{t} 2}$ is penetrative at all scales - macro-, meso- and micro-scale (Fig. 13b). 
Figure 13. Representative photographs and photomicrographs from the Mixed domain containing both cataclastic and fractured rocks. (a) Pavement view of foliated quartzite with fine-grained black phyllite interlayers and concordant quartz veins, all preserving the regional foliation. These rocks are cut at a high angle by conjugate sets of faults that are 10 $\mathrm{cm}$ in length. The faults have $1 \mathrm{~cm}$ offsets and are lined with black $\mathrm{mm}$-scale zones of ultracataclasite. (b) Photomicrograph of anastomosing $\mathrm{mm}$-scale ultracataclasite zones that cut the trace of the foliation at a high angle in the Mendocina orthogneiss. Note the $0.6 \mathrm{~mm}$ offset (black arrows) on the conjugate faults bounding a rock fragment - FOV $8 \mathrm{~mm}(2.5 \mathrm{x})$, cross polarized light. (c) Photomicrograph of anastomosing and transversal microfaults that are lined with ultracataclasite and very fine-grained chlorite that cut across a chloritic phyllite - FOV $8 \mathrm{~mm}$, plane polarized light. (d) Photograph of a chlorite-coated polished surface (e.g. red dashed lines) and cataclasite zone (e.g. black dashed lines) that crosscuts the trace of the $\mathrm{S}_{\mathrm{t} 2}$ foliation (black solid line) in a cataclastic quartzite with fine-grained black phyllite interlayers. 

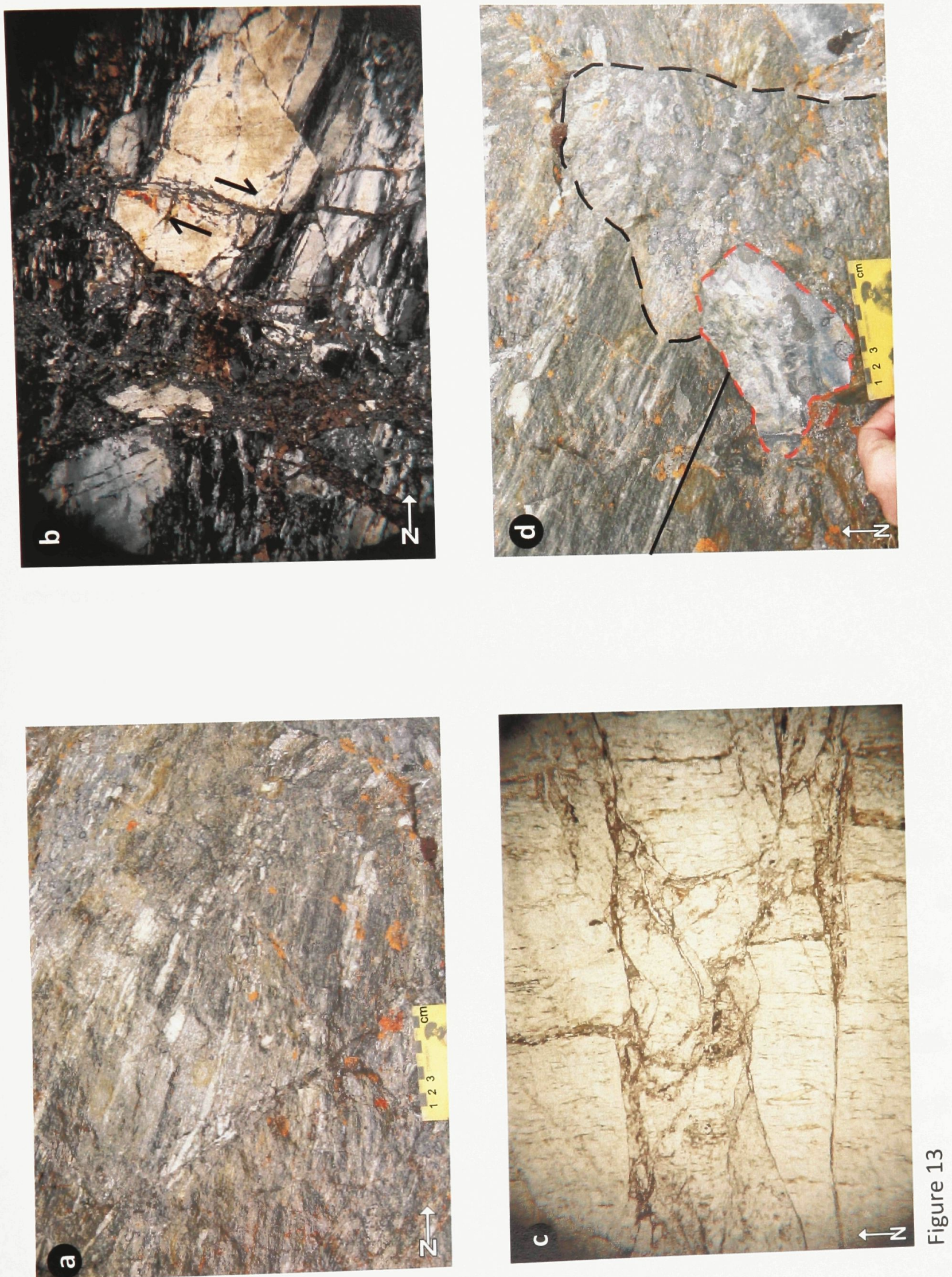
The shear fractures are steeply dipping and variably striking. They occur as anastomosing conjugates or single shear fractures, and locally as en-échelon fractures. Fractures have a spacing of $0.5-5 \mathrm{~mm}$, are $1-20 \mathrm{~cm}$-long, generally have $\mathrm{mm}$-scale displacement and bound 0.5-5 mm-wide lens-shaped rock fragments of unfoliated cataclasite to ultracataclasite (Fig. 13c). The fracture sets are apparently randomly oriented with respect to $\mathrm{S}_{\mathrm{t} 2}$. Other representative structures are: $1 \mathrm{~mm}$-wide seams, lining faults or fractures, with very fine-grained chlorite and unidentified dark material (Fig. 13c); chlorite-coated polished surfaces (Fig. 13d); fault surfaces with shallowly plunging slickenlines and stepped surfaces; and networks of calcite-chlorite-filled veins. Intracrystalline deformation microstructures include undulose extinction in quartz, microcracks in feldspar and twins in calcite.

Cohesive breccia is locally recognized in dolomitic marble of the Last Peak succession (map unit D on Fig. 4; localized breccia in Fig. 14). The breccia is made of randomly-shaped, angular and sharp 1-5 $\mathrm{mm}$ and up to $1-50 \mathrm{~cm}$ rock fragments (Fig. 14a). The fragments are bounded by fractures, with less than $10 \%$ fine-grained matrix and cemented by calcite and dolomite (Fig. 14b). Typical brittle structures include spaced and conjugate fractures that cut across $\mathrm{S}_{\mathrm{t} 2}$ (Fig. 14c). The calcite crystals vary in size from 1-4 $\mathrm{mm}$. Cavities are common and of various sizes ranging from $1 \mathrm{~cm}$ cube to $25 \mathrm{~cm}$ long by $15 \mathrm{~cm}$ wide and $2 \mathrm{~cm}$ deep. They are either parallel to $\mathrm{S}_{\mathrm{t} 2}$ or cut across it at high angle. Some cavities are commonly filled with calcite crystals that are oriented perpendicular to the cavity walls. In thin section, the breccia (microbreccia) is made of < 
Figure 14. Representative photographs and photomicrograph of rocks from the localized breccias in the Mixed domain. (a) Northward view of an outcrop of dolomitic marble breccia with sets of spaced fractures. (b) Mesoscopic view of a dolomitic marble breccia made of $\mathrm{cm}$-size angular fragments surrounded by carbonate cement. The rock has multiple sets of randomly oriented, brittle, spaced fractures. (c) Looking down at a breccia zone that is overprinting a marble raft with a Cal-Tr-Grt-Di contact aureole. Spaced fractures are filled with calcite. Conjugate fractures cut across the trace of the relict regional foliation at high angle. (d) Photomicrograph of fine crush breccia in calc-silicate rock in a marble raft in the Last Peak granite. The large grey crystal in the center is fractured and filled with calcite FOV $4 \mathrm{~mm}(5 \mathrm{x})$, cross polarized light. 

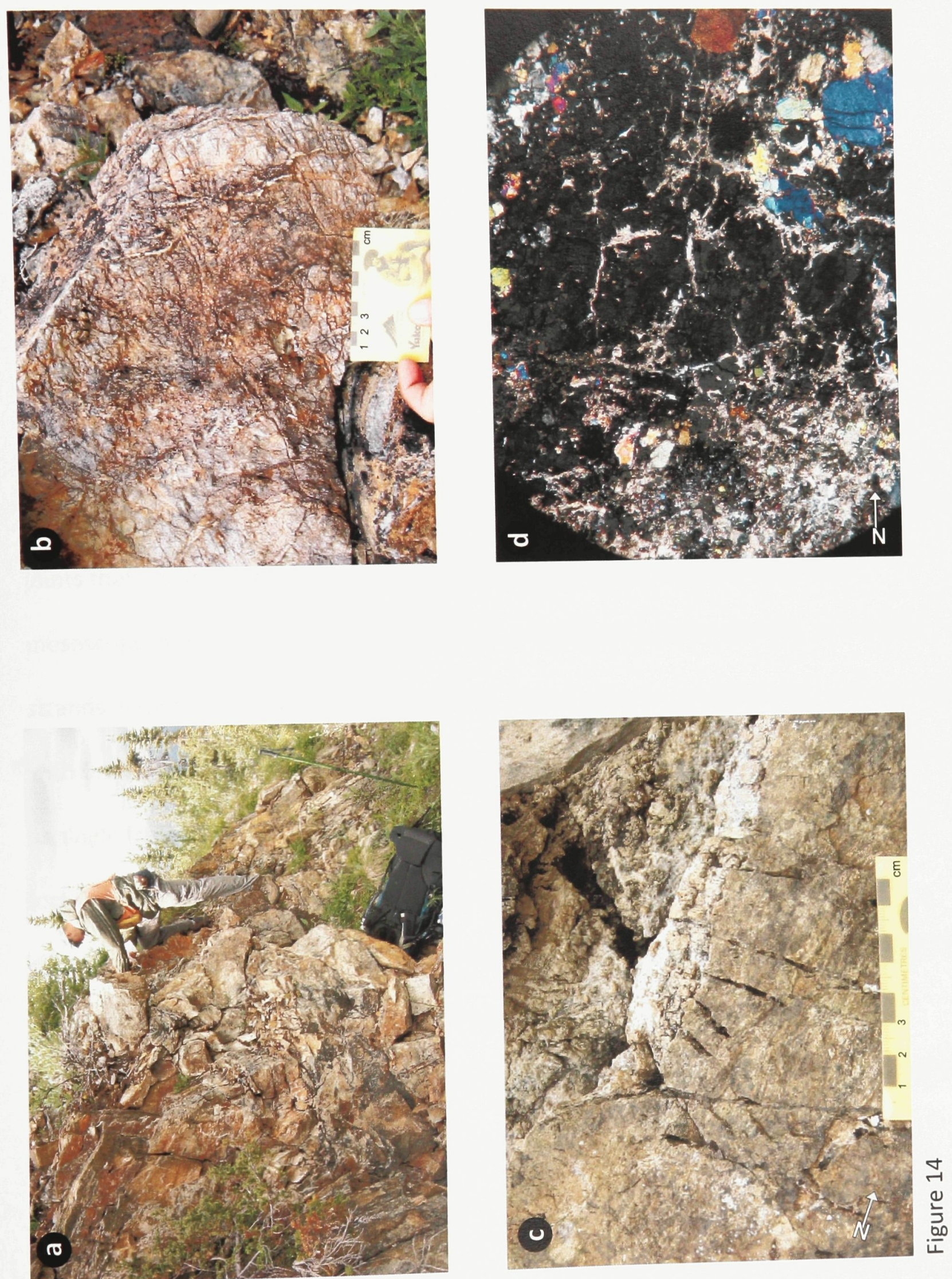
$1 \mathrm{~mm}$ fragments that are surrounded by less than $10 \%$ matrix and interstitial calcite

(Fig. 14d). Some crystals are fractured and filled with calcite. Grains are subhedral to anhedral, and grain boundaries are serrated. Intracrystalline deformation includes grainboundary bulging, kinking and microfracturing (Fig. 14d).

\section{Fracture domain}

The Fracture domain is a zone where rocks are characterized by sets of steeply dipping and variably striking shear fractures (Fig. 15a). The $S_{t 2}$ in the host rocks is generally well preserved and can be followed for kilometres along strike. It is locally truncated by the shear fractures. Fractures in this zone are different from fractures and joints that occur elsewhere in the field area because they are organized at the mesoscopic-scale, and typically reflect the overall structural arrangement of the fault strands within the d'Abbadie fault zone (Fig. 15b). Fractures are generally $1-30 \mathrm{~cm}$-long, with 0.5-5 $\mathrm{mm}$ spacing and occur within sparse areas of approximately $20 \mathrm{~cm}$ square, or as single fractures that cut across $\mathrm{S}_{\mathrm{t} 2}$. Conjugate shear and en-échelon fractures occur locally (Fig. 15c). The fractures are filled, partly filled or unfilled. They are found in different sizes from 1-70 cm-long by 1-3 mm-wide, and are arranged in stockwork or as single fractures. The fractures cut $\mathrm{S}_{\mathrm{t} 2}$ at high angle or are concordant to it. Filling material consists of quartz, calcite, quartz-calcite, calcite-quartz, chlorite-calcite and/or pyrite-chlorite-calcite. Typical microstructures include microcracks in quartz and feldspar grains (Fig. 15d). 
Figure 15. Representative photographs and photomicrograph of rocks from the Fracture domain. (a) Looking down at a foliated dolomitic muscovite-phyllite that is cut by fractures. Note the rusty orange-coloured calcite-dolomite-filled open-spaced fracture (center). (b) Same as (a) but shows the line interpretation for the fractures. (c) Western view of a steeply dipping foliation surface in a biotite schist showing the traces of multiple parallel fractures and calcite-filled en-échelon fractures (arrow). (d) Photomicrograph showing a single fracture filled with calcite that cuts the trace of the foliation in a biotite schist. Calcite also coats intercrystalline grain boundaries. Quartz grains have microcracks (c) - FOV $2 \mathrm{~mm}$ (10x), cross polarized light. 

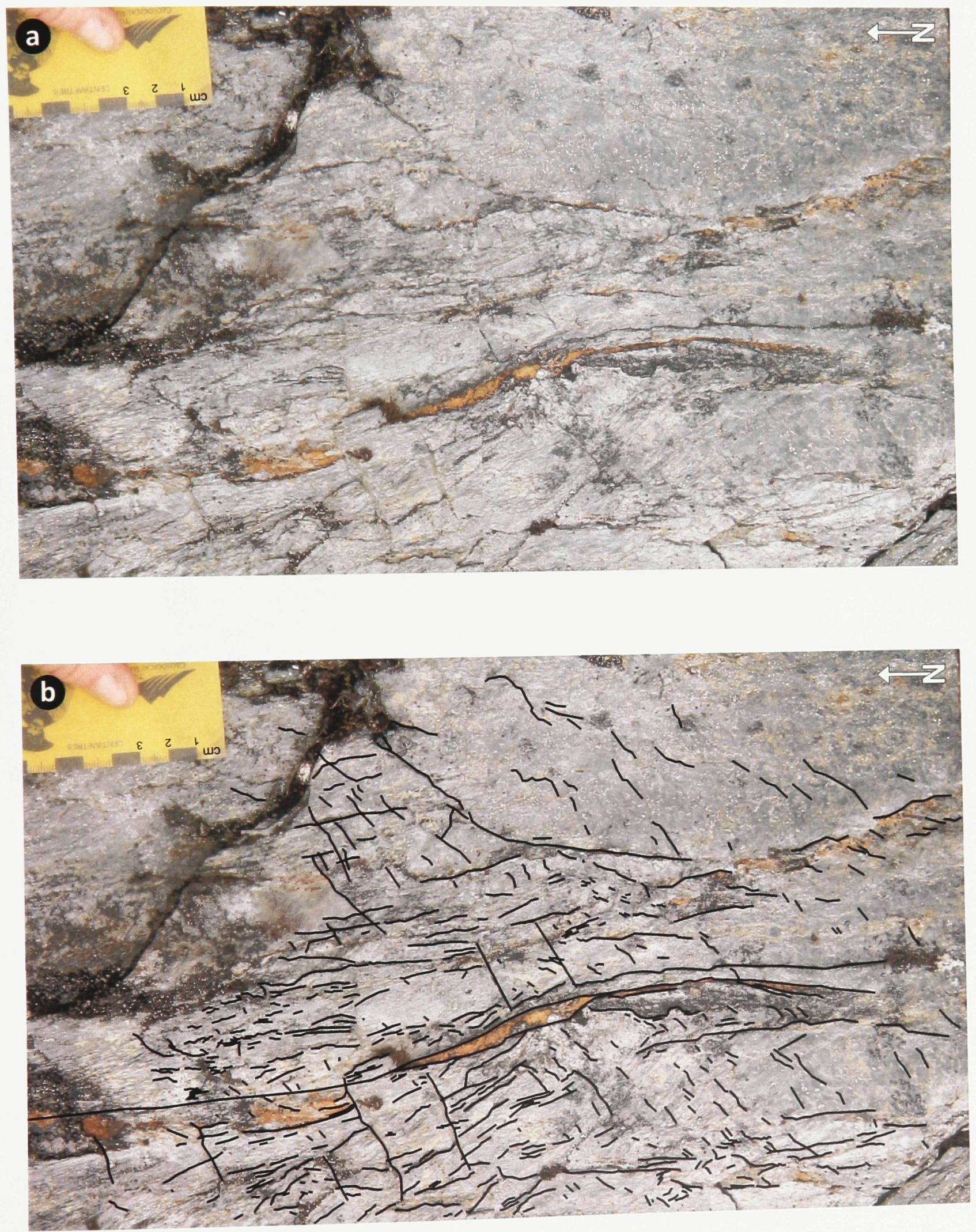

Figure 15 

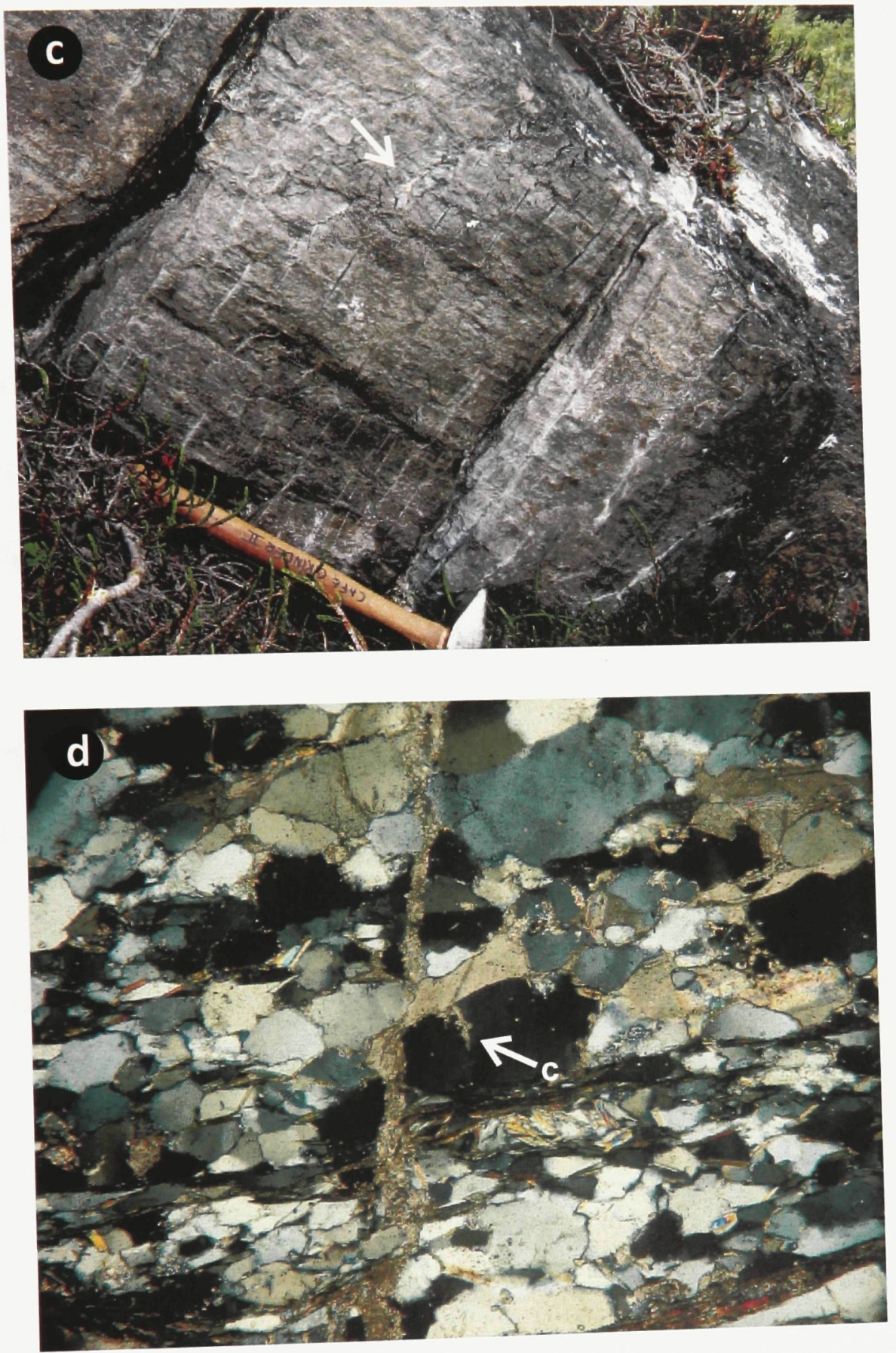

Figure 15 (cont'd) 
3.1.2 Mylonitic rocks localized in the Last Peak granite

The purpose of this section is to describe the mylonitic rocks, characterized as SC mylonites (Berthé et al. 1979), in the Last Peak granite. The mylonitic rocks have been classified using Twiss and Moores's (2007) fault rock classification, focusing on the percentage of matrix versus porphyroclasts. Protomylonites are made of $<50 \%$ matrix, mylonites are made of 50-90\% matrix, and ultramylonites are made of $>90 \%$ matrix. The reference to the shear foliation (C-plane) as weak, moderate, or strong is on the basis of its development and continuity throughout the rock. The matrix grain size ranges from very fine to fine $(\leq 1 \mathrm{~mm})$.

S-C mylonites occur in three domains from west to east: the Protomylonite, Mylonite, and Ultramylonite domains (Fig. 16). The domains have been determined on the basis of the grain size of the matrix and porphyroclasts, percentage of matrix with respect to the porphyroclasts, spacing between the C-planes, and the angle between the S- and C-planes. The domains share gradational contacts. The contact lines drawn on the map are based on the best approximation of the middle of the gradation. The description of representative mylonitic rocks and their microstructures for each domain is presented below, and compiled in Tables 3 and 4.

The term "mylonite" or "mylonitic" in this study refers to a rock with a foliation and a lineation. It also refers to a rock that was deformed as a result of grain-size reduction without loss of cohesion, and went through ductile deformation, recovery and recrystallization processes (Bell and Etheridge 1973). The nomenclature used (e.g. S-C 
Figure 16. (a) Structural domain map of the Last Peak granite showing the distribution of protomylonites, mylonites and ultramylonites in terms of three strain domains termed the Protomylonite, Mylonite and Ultramylonite domains. The inset map shows the location of the Last Peak granite in the study area (Figure 6). Structural symbols on the map show the orientation of shear planes ( $\mathrm{C}$ planes) and stretching lineations. The domain contacts are gradational. The contact lines were drawn based on the best approximation of the center of the gradation. (b, c, d) Representative photographs of (b) protomylonite, (c) mylonite and (d) ultramylonite from each domain. Photographs are taken looking at the plane perpendicular to the foliation and parallel to the lineation (e.g. motion plane). Note the decrease in grain size of the matrix and porphyroclasts, increase in percentage of matrix with respect to porphyroclasts, decreased spacing between the C-planes, and decreased angle between the S- and C-planes from (b), to (c), and to (d). Such variation in development of mylonitic structures suggests a strain gradient increasing eastward, towards the centre of the d'Abbadie fault zone. 


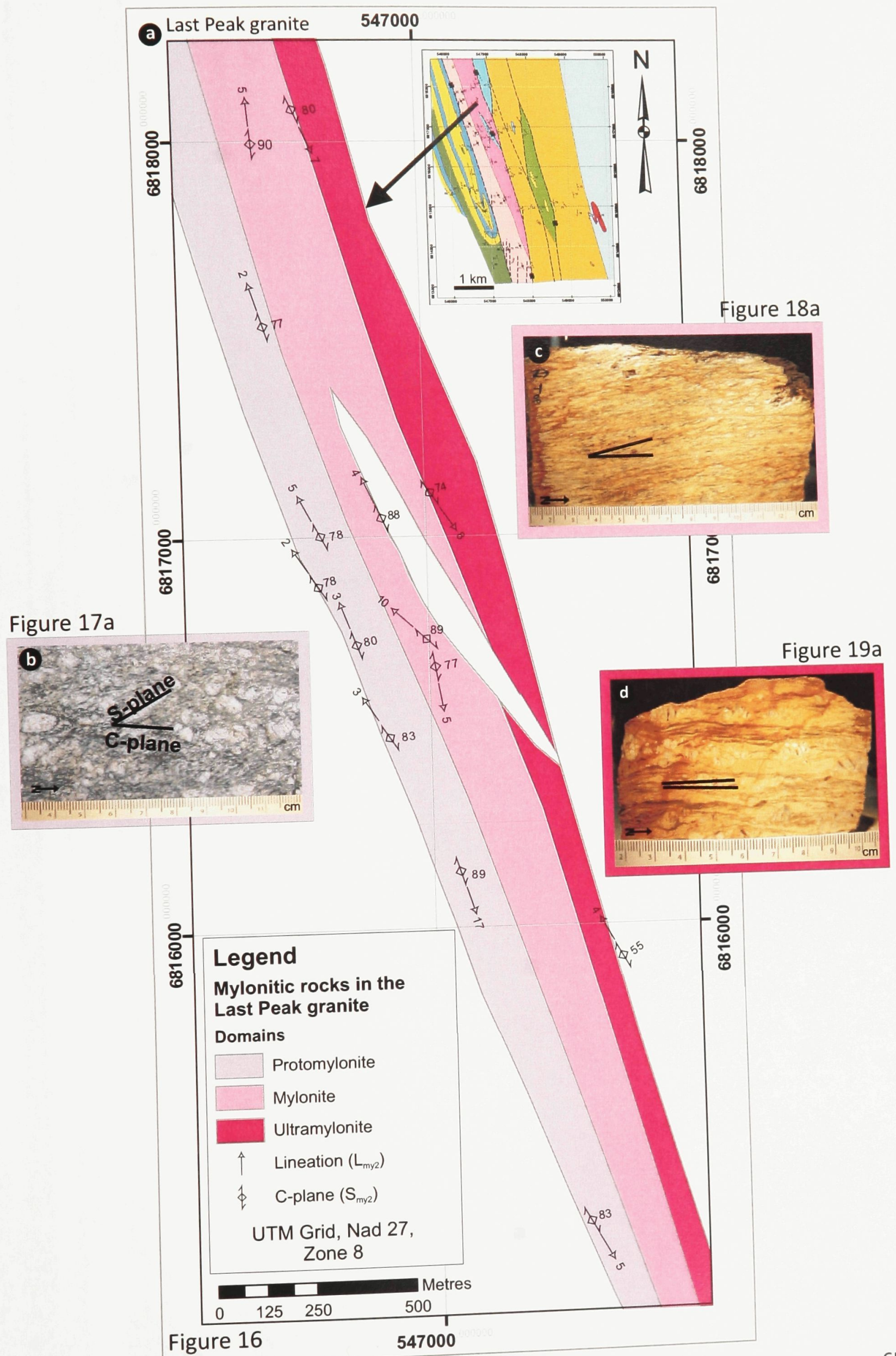




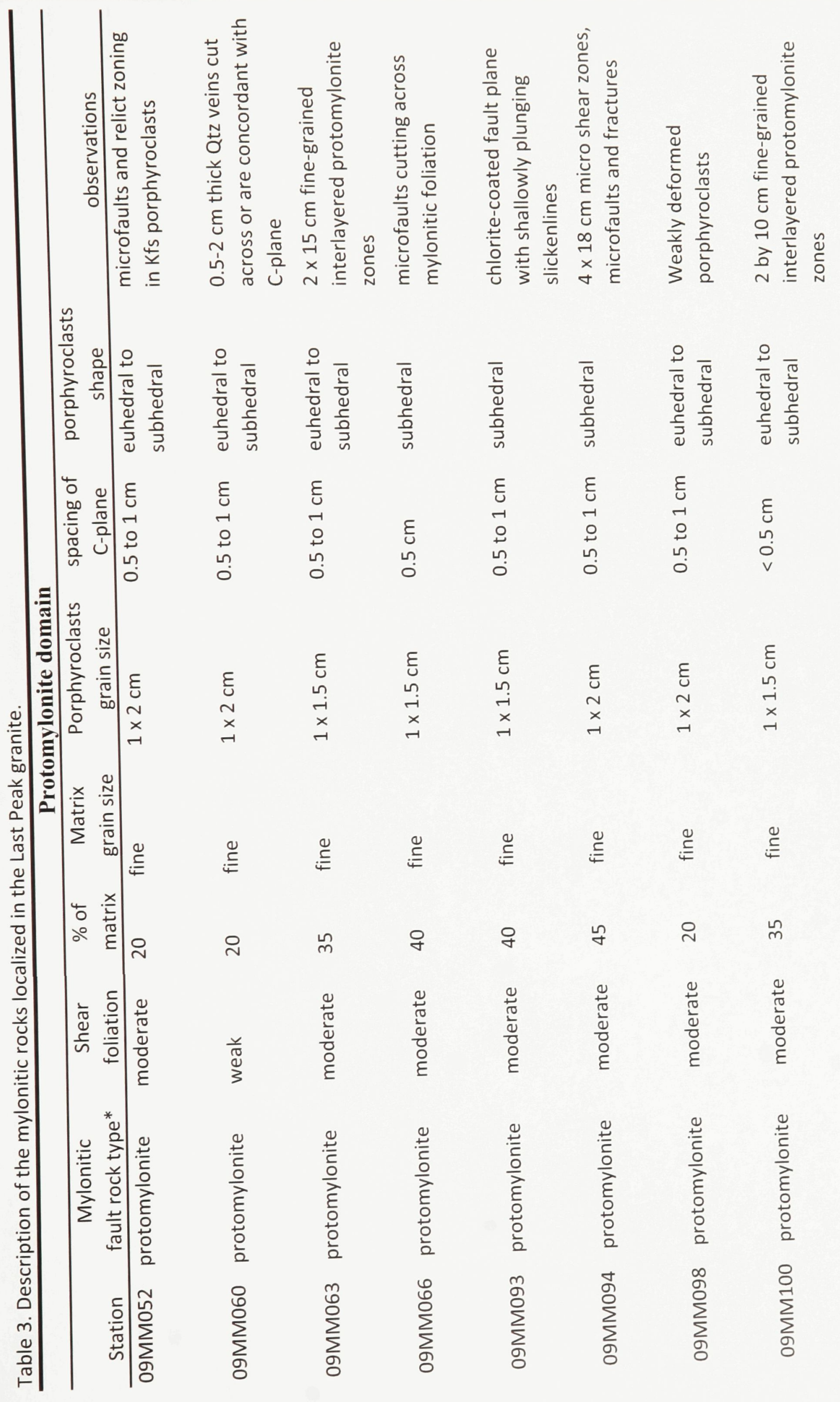




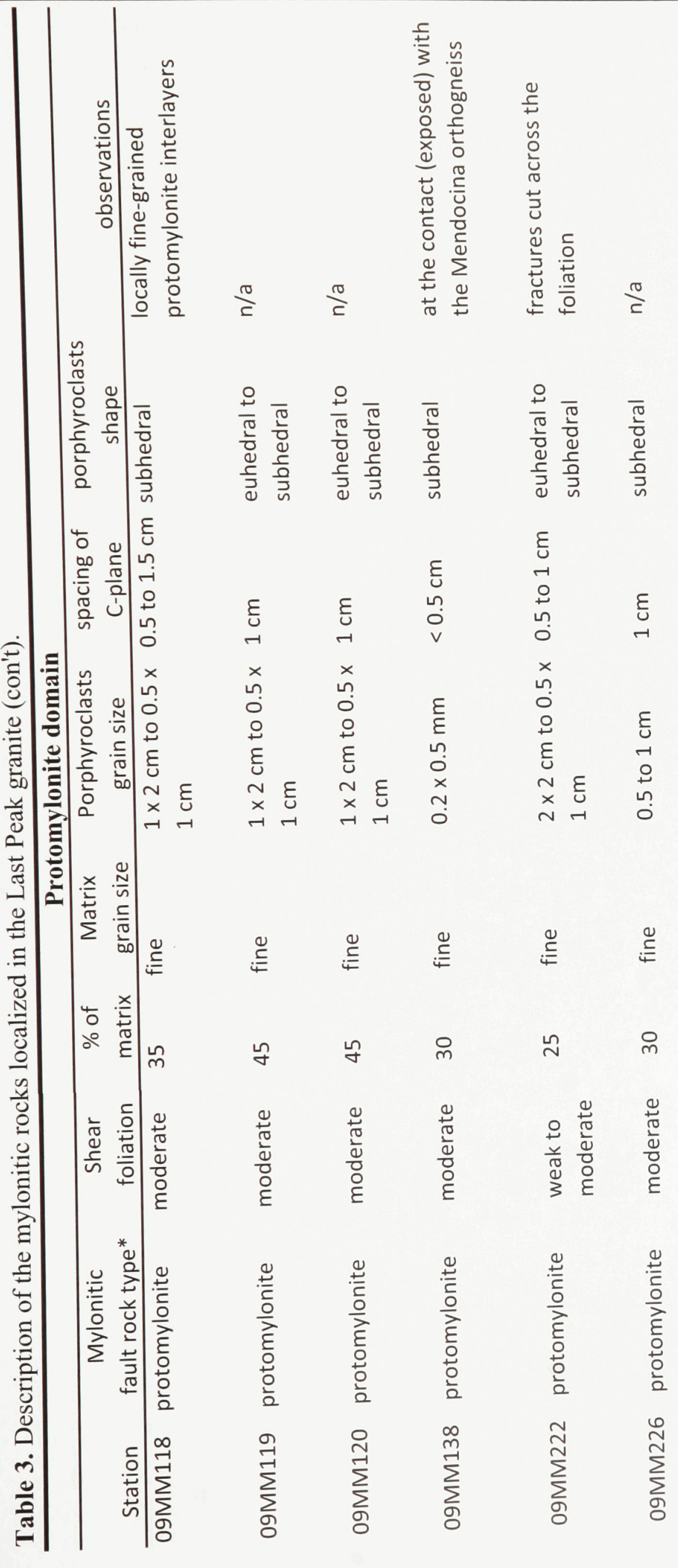




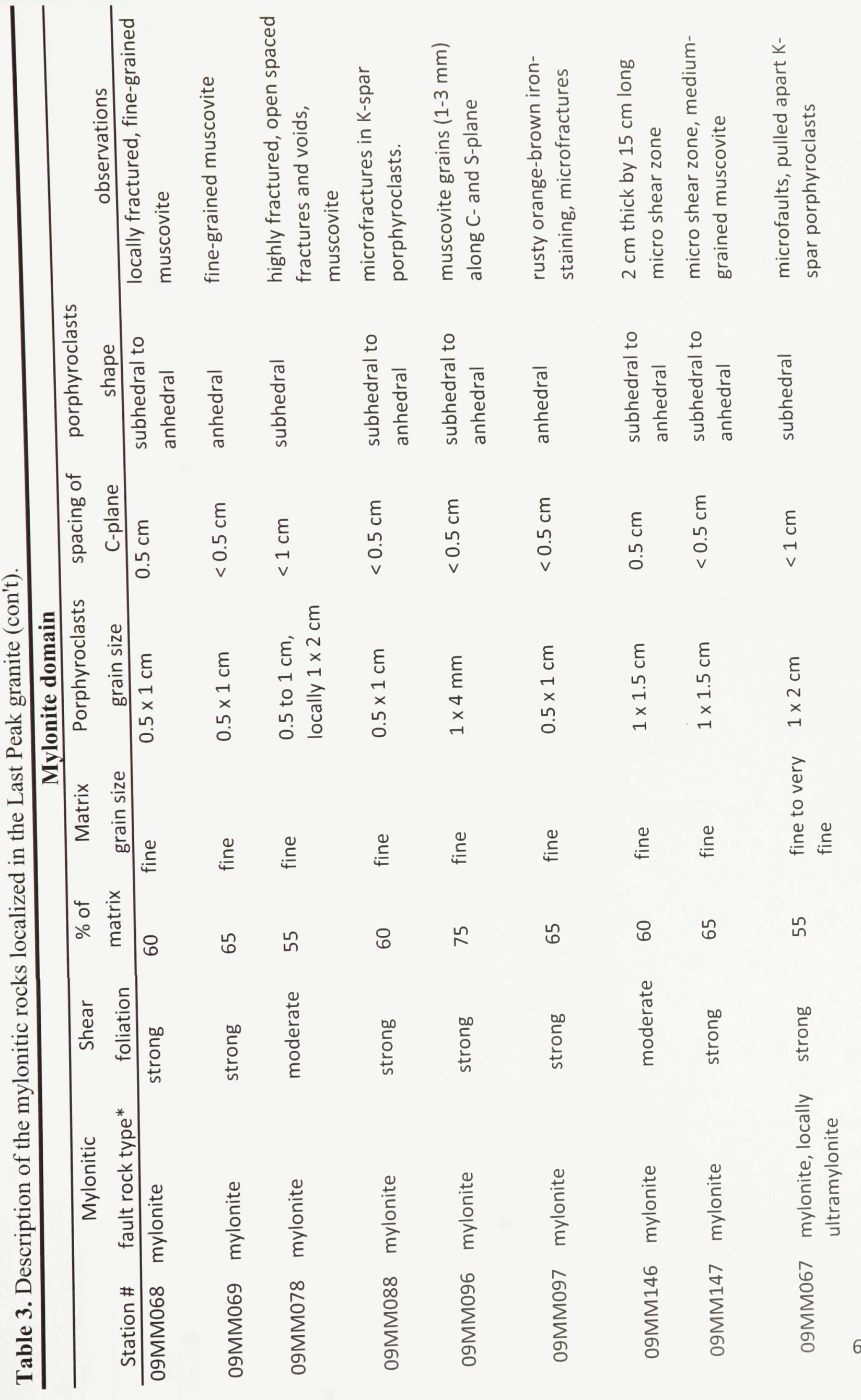




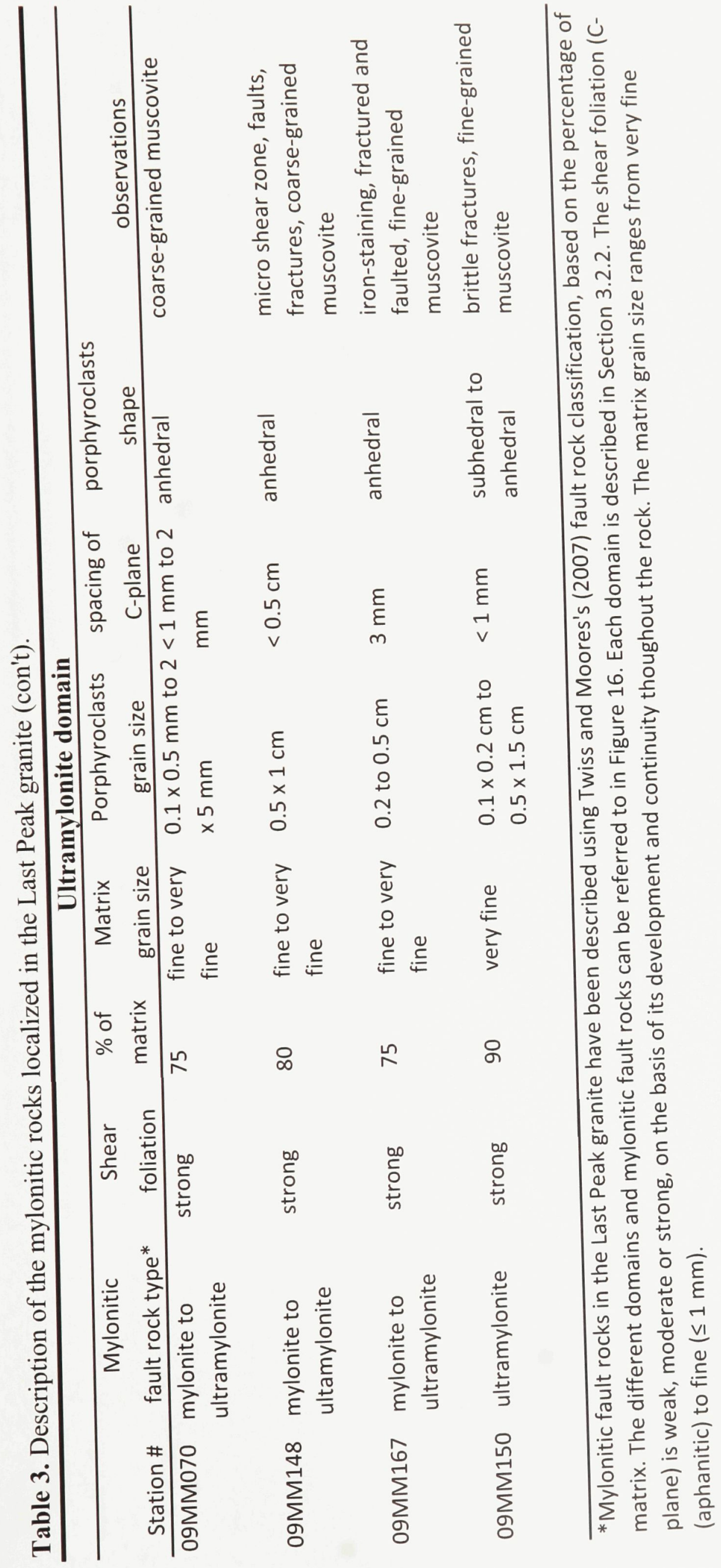




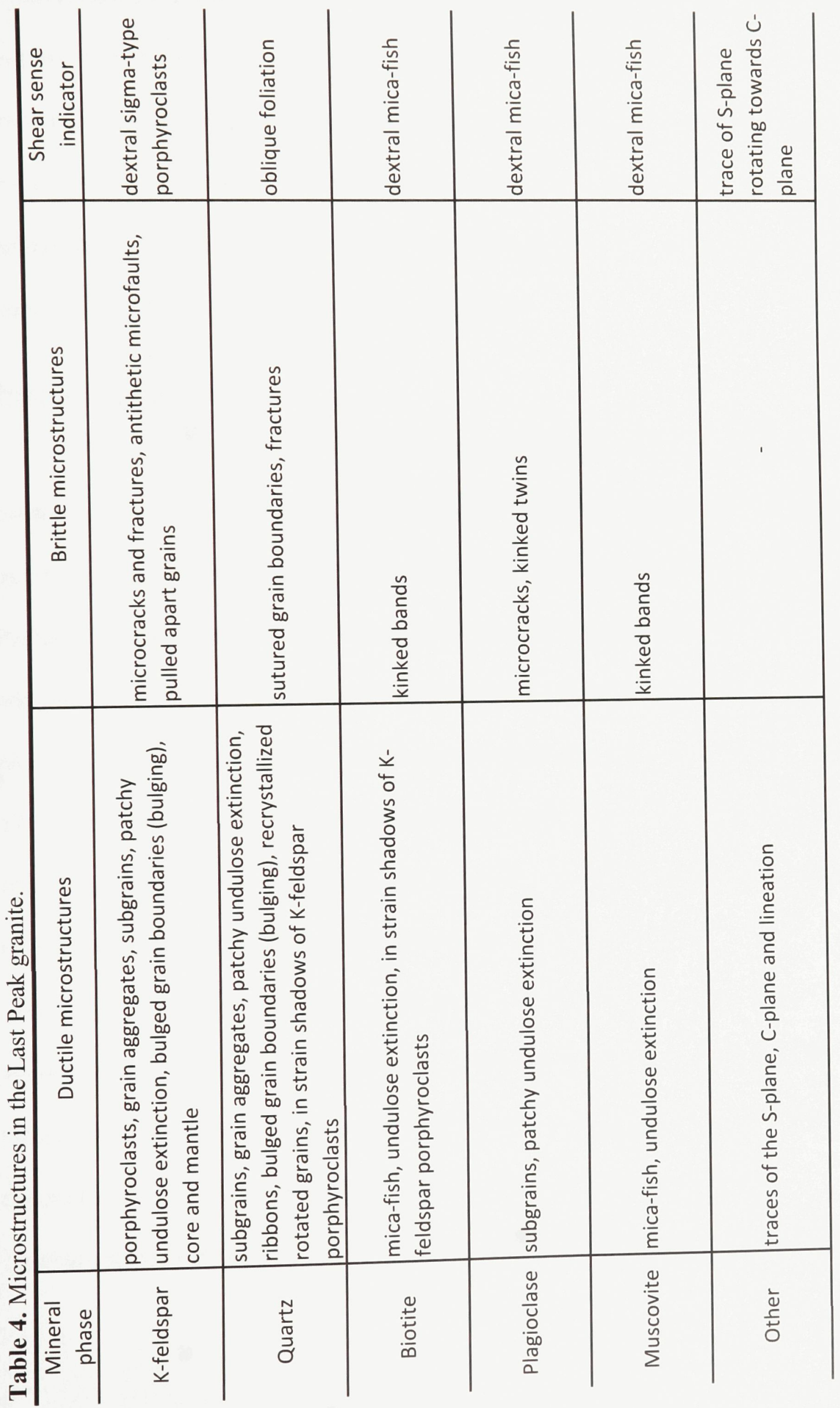


mylonite) is from Berthé et al. (1979), Passchier and Trouw (1996) and Vernon (2004), where the predominant shear foliation or $\mathrm{C}$-plane $(\mathrm{C}=$ 'cisaillement', French word for shearing) is parallel to the compositional layering and interpreted as concordant with the shear zone boundaries. The S-plane ( $\mathrm{S}=$ 'schistosité', French for schistosity) is defined by the preferred alignment of mineral grains in the rock and is interpreted to represent the flattening plane of the strain ellipse.

\section{Protomylonite domain}

The Protomylonite domain is approximately 60-130 m-thick. It consists of medium-grained protomylonites, comprising 10-50 \% biotite-plagioclase-K-feldsparquartz matrix and 1 by $2 \mathrm{~cm} \mathrm{K-feldspar}$ and plagioclase porphyroclasts (Fig. 17a).

Protomylonites are characterized by a steeply dipping, NW-SE striking, 0.5-1 cm-spaced and poorly to moderately developed C-planes; NW-SE striking S-planes; and shallowlyplunging, NW-SE trending, and a moderately developed quartz stretching lineation (Fig. 17b). The C-planes are defined by flattened quartz aggregates, quartz-filled tails (i.e. strain shadows) of K-feldspar porphyroclasts and the preferred alignment of fine- to medium-grained biotite. The S-planes are defined by the long axis of K-feldspar porphyroclasts and biotite-fish. K-feldspar porphyroclasts are generally equant to weakly oblate. They also may be pulled apart or with quartz-filled strain shadows. Intracrystalline deformation microstructures include patchy undulose extinction and subgrains in quartz; subgrains, microcracks and microfractures in K-feldspar porphyroclasts; and kink bands in biotite. In addition, the western edge of this domain is 
Figure 17. Representative photograph and photomicrographs of protomylonites from the Protomylonite domain in the Last Peak granite. Photomicrographs, illuminated in crossed polarized light. Thin sections are oriented parallel to the lineation and perpendicular to the foliation (e.g motion plane). (a) Hand sample of protomylonite. (b) Protomylonite composed of strongly fractured K-feldspar $(\boldsymbol{K} f s)$ and plagioclase $(\boldsymbol{P I})$ porphyroclasts in a fine- to medium-grained biotite-feldpar-quartz matrix. Note the quartz (Qtz) subgrains - FOV $8 \mathrm{~mm}$ (2.5x), cross polarized light (XPL). (c) Flame perthite (e.g. red stripes) in K-feldspar porphyroclast in a fine-grained protomylonite located at the western boundary of the western domain - FOV $1 \mathrm{~mm}(20 \mathrm{x})$, XPL. 

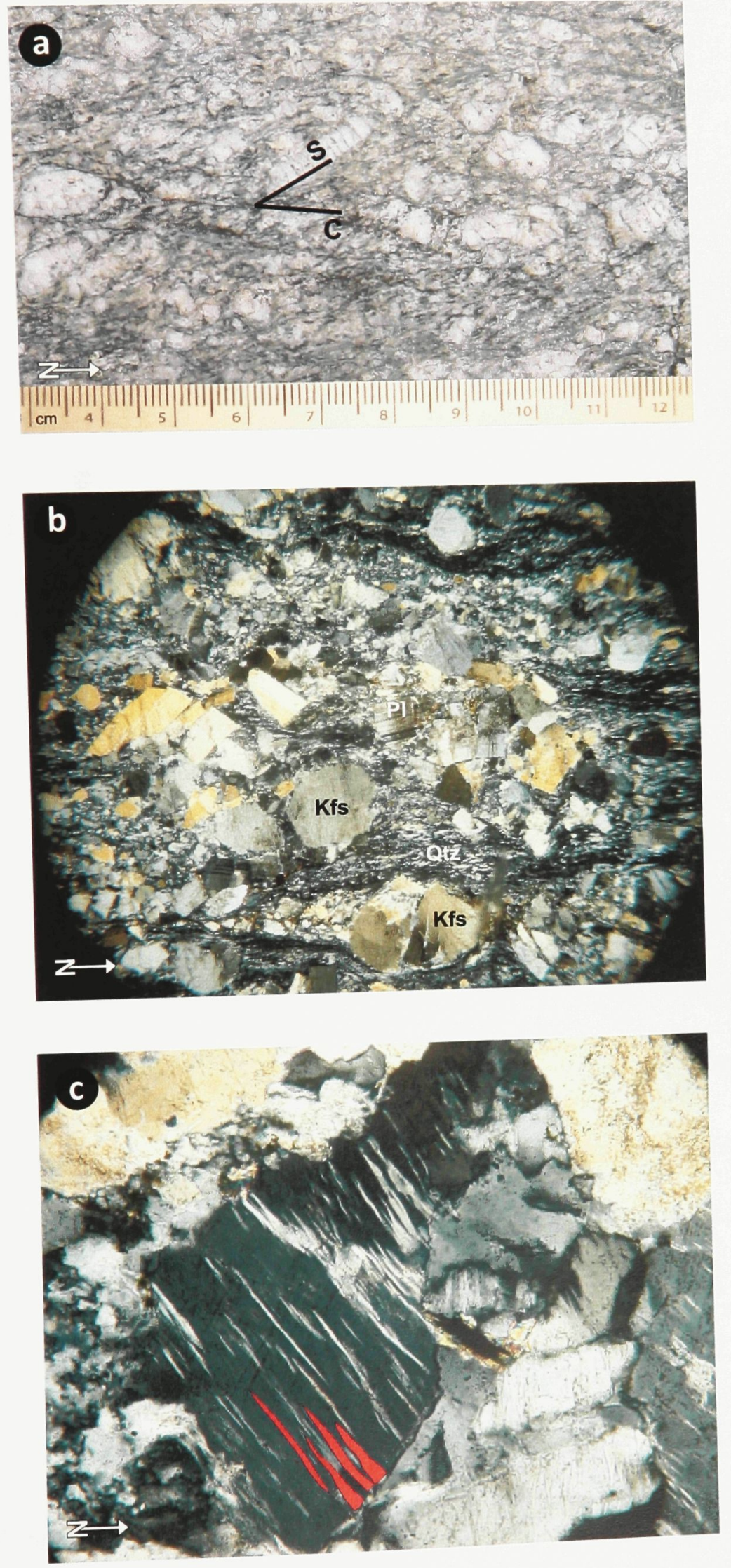

Figure 17 
characterized by finer-grained protomylonites and the common occurrence of flame perthite (Fig. 17c) in the K-feldspar porphyroclasts.

\section{Mylonite domain}

The Mylonite domain is approximately 100-140 m-thick. It consists of mediumto fine-grained mylonite comprising 50-90 \% biotite-plagioclase-K-feldspar-quartz matrix and 0.5 by $1-1.5 \mathrm{~cm} \mathrm{K-feldspar} \mathrm{porphyroclasts} \mathrm{(Fig.} \mathrm{18a).} \mathrm{Mylonites} \mathrm{are} \mathrm{characterized} \mathrm{by}$ a steeply-dipping, NW-SE striking, 0.5-1 cm-spaced to continuous ( $<1 \mathrm{~mm})$, and strongly developed C-planes; NW-SE striking S-planes; and shallowly-plunging, NW-SE trending pervasive quartz stretching lineation (Fig. 18b). The C-planes are defined by flattened quartz grains with undulose extinction, quartz ribbons, and the preferred alignment of fine-grained biotite. The S-plane is defined by the long axis of K-feldspar grains and biotite fish. K-feldspar porphyroclasts are generally equant to weakly oblate. They also commonly have microcracks, microfaults, or may be asymmetric with sigma-type quartz-filled strain shadows. Biotite and muscovite fish are commonly kinked (Fig. 18c). Intracrystalline deformation microstructures include patchy undulose extinction and subgrains in quartz; subgrains, core and mantle structures, microcracks and microfractures in K-feldspar porphyroclasts; and kink bands in biotite and muscovite.

\section{$\underline{\text { Ultramylonite domain }}$}

The Ultramylonite domain is approximately $40-70 \mathrm{~m}$-thick. It consists of ultramylonites and locally mylonites. Ultramylonites comprise $90 \%$ sericite-biotite-Kfeldspar-quartz matrix and 0.1-0.5 mm to 0.5-1 cm K-feldspar porphyroclasts (Fig. 19a). 
Figure 18. Representative photograph and photomicrographs of mylonites from the Mylonite domain of the Last Peak granite. The photomicrographs are illuminated in crossed polarized light and looking at the motion plane. (a) Hand sample of mylonite. (b) Photomicrograph of mylonite composed of anhedral and fractured K-feldspar porphyroclasts in a fine-grained biotite-feldspar-quartz matrix. Note the microcracks in the K-feldspar porphyroclast (center) and the well-developed biotite fish - FOV $4 \mathrm{~mm}(5 \mathrm{x})$, cross polarized light (XPL). (c) Photomicrograph of kink banding in biotite - FOV $0.5 \mathrm{~mm}$ (40x), XPL. 

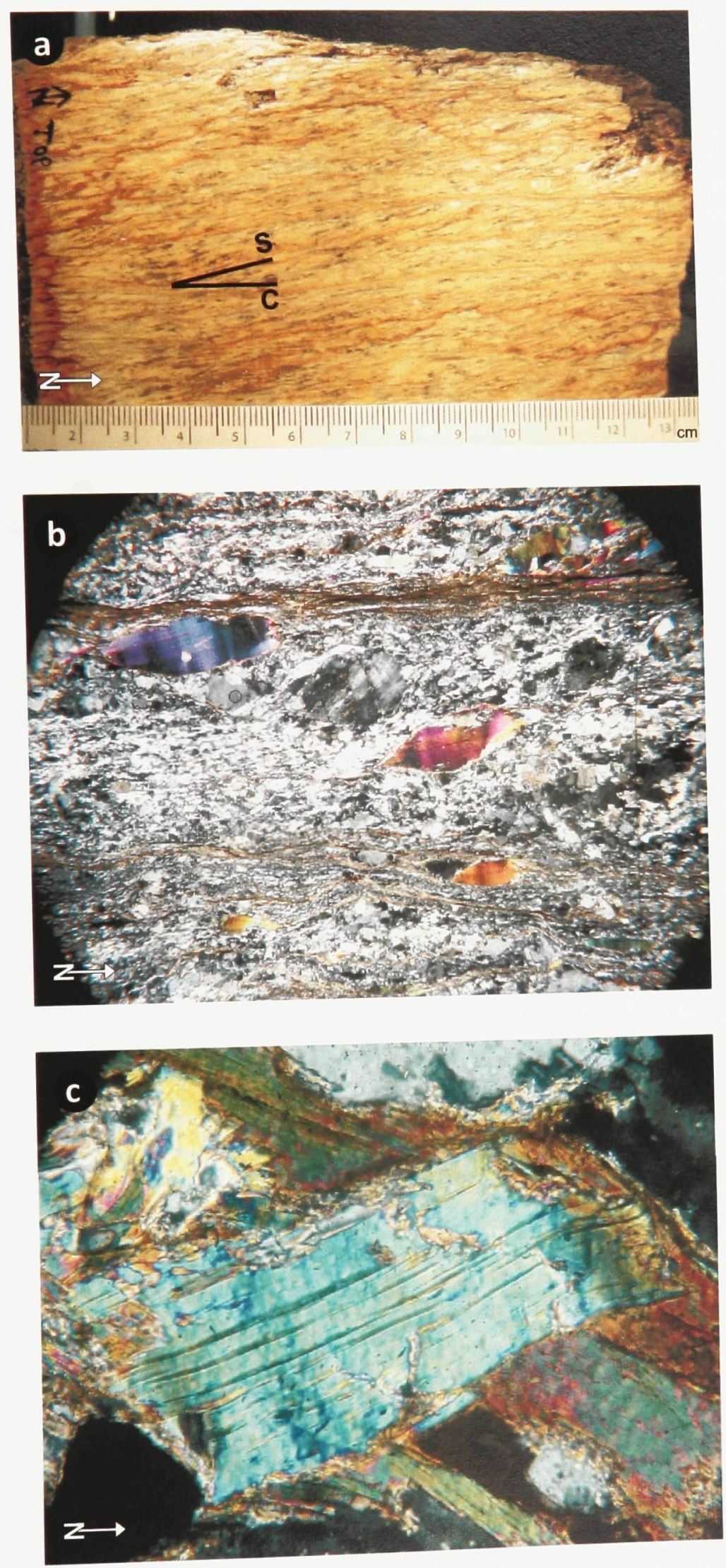

Figure 18 
Figure 19. Representative photograph and photomicrographs of ultramylonites from the Ultramylonite domain in the Last Peak granite. The photomicrographs are illuminated under crossed polars and are oriented looking at the motion plane. (a) Hand sample of ultramylonite with fractured K-feldspar porphyroclasts that lie within the S-plane and welldeveloped grey quartz ribbons that lie within the C-plane. Note that the C-plane is represented by both the trace of the foliation and the compositional banding. The matrix is leucocratic and aphanitic. (b) Photomicrograph of ultramylonite with K-feldspar porphyroclasts and quartz ribbons in a very fine grained biotite-feldspar-quartz matrix, with very fine-grained muscovite - FOV $8 \mathrm{~mm}(2.5 \mathrm{x})$, cross polarized light (XPL). Note the contrast in the appearance of the K-feldspar porphyroclast and quartz ribbons between (a) and (b), where what may look like a single crystal in hand specimen is actually an aggregate of crystals in thin section. (c) Photomicrograph of quartz subgrains that have experienced grain-boundary bulging - FOV $1 \mathrm{~mm}(20 \mathrm{x})$, XPL. 

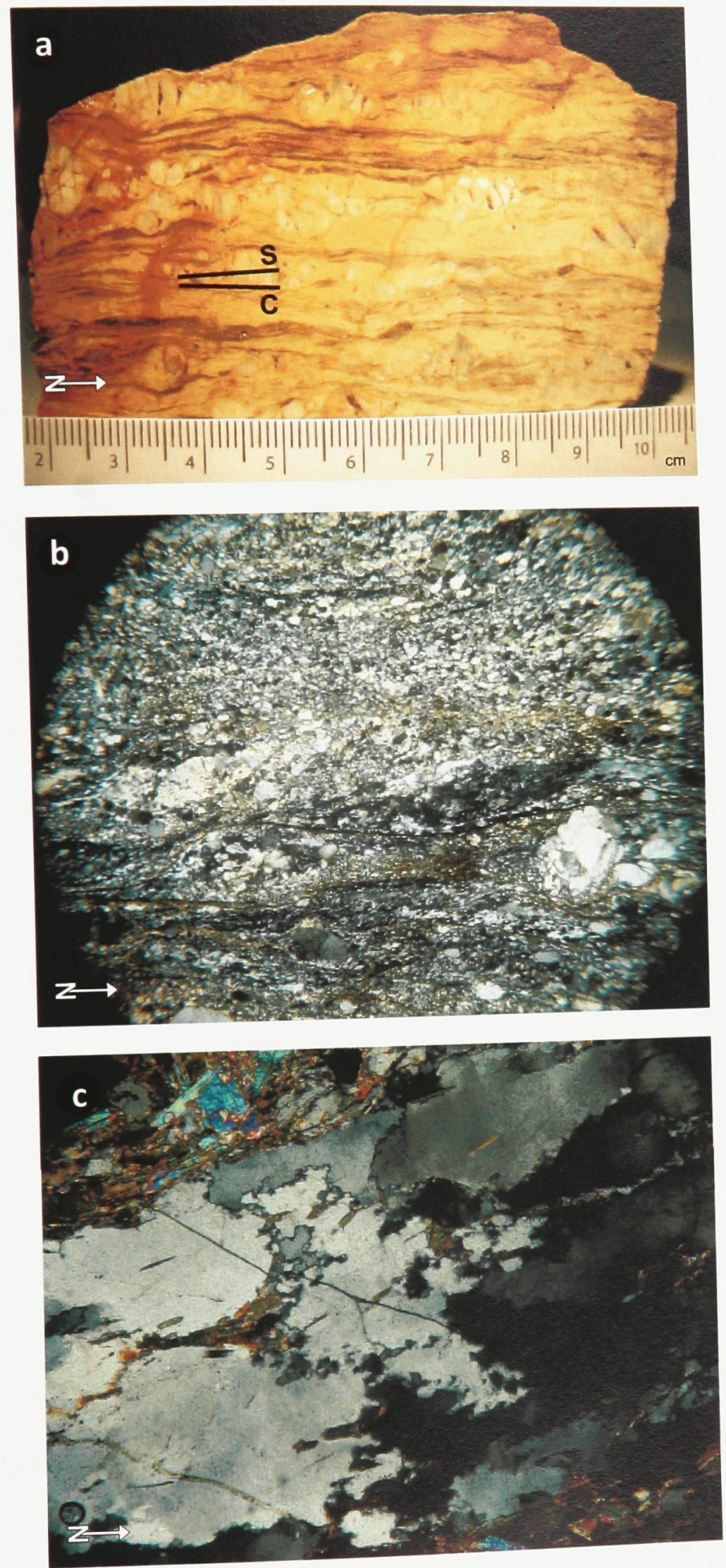

Figure 19 
They are characterized by steeply-dipping, NW-SE striking, and strongly developed Cplanes; NW-SE striking S-planes; and a shallowly-plunging, NW-SE trending, and pervasive quartz stretching lineation. The C-planes are defined by flattened quartz ribbons, quartz new grains, pyrite, very fine-grained chlorite and the preferred alignment of fine-grained to very fine-grained muscovite. The S-planes are generally defined by the long axis of K-feldspar grains, biotite fish, and locally muscovite fish. Kfeldspar porphyroclasts are generally equant to weakly oblate. They commonly have microcracks and/or microfaults, and may be asymmetric with sigma-type quartz-filled strain shadows. Mineral grains that may appear as single crystals in hand specimen are often made of a combination of subgrains in thin section (Fig. 19b). This is the case for K-feldspar porphyroclasts and quartz ribbons. Intracrystalline deformation microstructures include patchy undulose extinction, subgrains and bulged grain boundaries in quartz (Fig. 19c); subgrains, and core and mantle structures in K-feldspar; and kink bands in biotite and locally in muscovite.

The eastern and western margins of this domain are characterized by localized 1 $\mathrm{mm}$ to $2 \mathrm{~cm}$-wide cataclasite zones that cut the mylonitic foliation at high angle (Fig. $20 a, b)$. Other common brittle structures, similar to those of the brittle rocks in the d'Abbadie fault zone, include steeply dipping brittle faults with slickenlines and stepped surfaces (Fig. 20c), fault planes with very fine-grained chlorite-coated polished surfaces (Fig. 20d; Colpron 2006b; this study), and apparently randomly oriented open-space fractures. 
Figure 20. Brittle structures that crosscut the mylonites in the Last Peak granite. (a) Southward view of the trace of black $2 \mathrm{~mm}$-wide ultracataclasite lining the trace of a steeply dipping, $8 \mathrm{~cm}$ long brittle fault that cuts the trace of the mylonitic foliation at high angle (black dashed lines). (b) Photomicrograph, looking at the motion plane, of a mylonite from the Central domain with a lense shaped, localized cataclasite zone (surrounded by white dashed lines) - FOV $8 \mathrm{~mm}$ (2.5x), cross polarized light. The traces of the C- and S-planes (red lines) are crosscut by the cataclasite zone. (c) Southeastward view of a steeply dipping fault surface. The block represents the orientation of the fault surface and the opposing side of the fault. The fault surface has shallowly plunging slickenlines (black line) and stepped surfaces that are oriented perpendicular to the lineation, and are interpreted to step down to the north. The orientation of the stepped surfaces on the block suggests dextral sense of shear. Scale card is $9 \mathrm{~cm}$ long. (d) Looking south at a very fine-grained chlorite-coated polished surface of a fault plane cutting across the mylonitic foliation. 

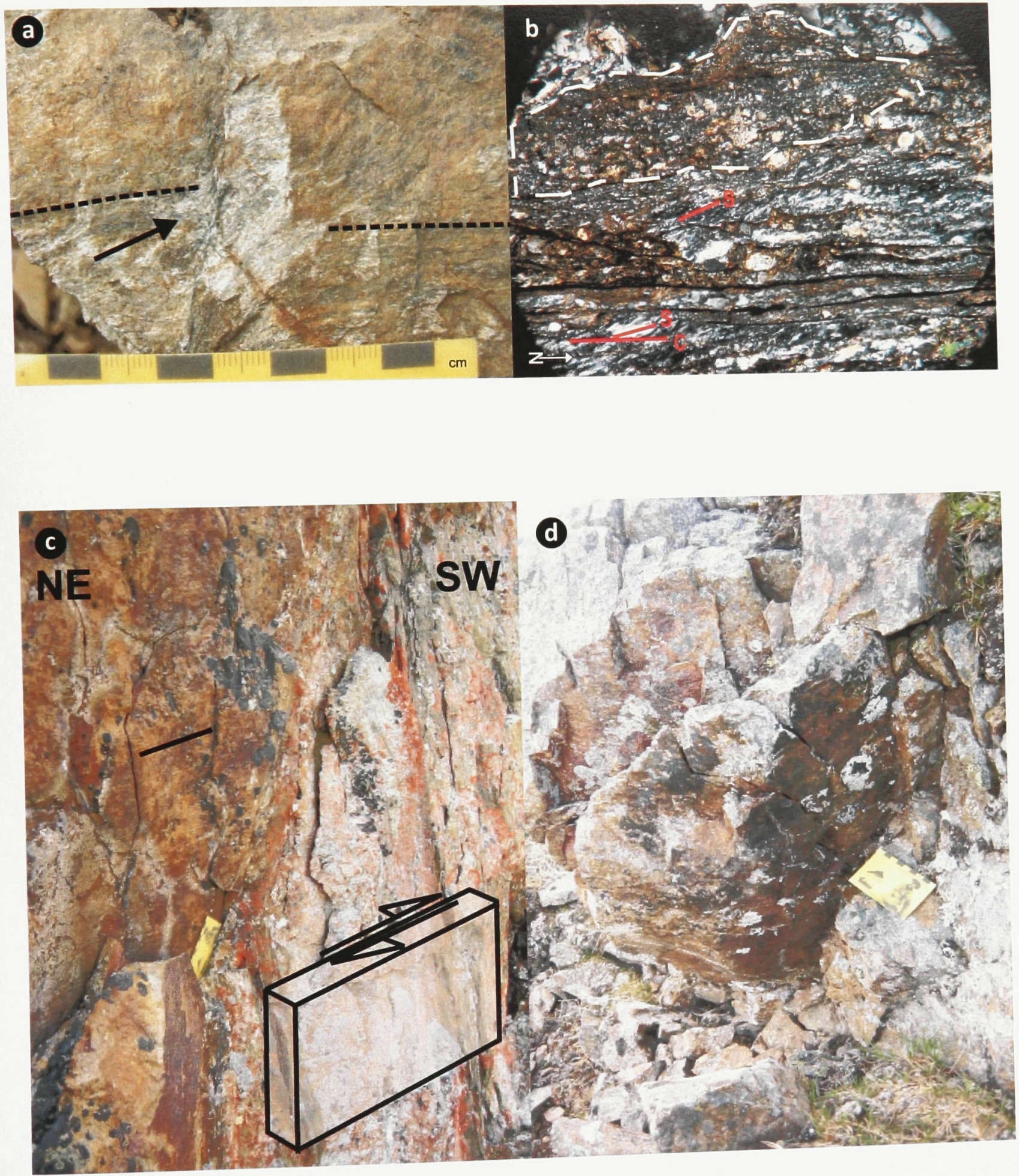

Figure 20 


\subsection{Fault structures within a representative transect across the d'Abbadie fault zone}

The goals of this section are to define what the author intends by fault "zone", describe the faults within the d'Abbadie fault zone and the basis for their interpretation, and introduce shear sense indicators. Textbook-style strike-slip faults are generally depicted as a single vertical fault bounded by two homogeneous blocks that moved past one another; however, the d'Abbadie fault zone is made of multiple faults so this model does not apply.

\subsubsection{Faults}

Twiss and Moores (2007) define a fault as "a surface or a narrow zone along which one side has moved relative to the other in a direction parallel to the zone", where faults are brittle shear fractures, zones of closely spaced shear fractures or zones of ductile shear. The term fault is also scale dependant such that it is used to represent metre to kilometre-scale shear fractures. In turn, similar centimetre-scale structures may be referred to as shear fractures (Twiss and Moores 2007).

The d'Abbadie fault zone is made of multiple anastomosing, spaced, variably striking (Fig. 21a) and steeply dipping (Fig. 21b) strike-slip faults, shear fractures and a localized ductile shear zone in the Last Peak granite. de Keijzer (1999) suggested that there was a late component of normal-slip along the d'Abbadie fault zone. Although sets of conjugate fractures are locally found in the d'Abbadie fault zone within the study area, this study support that there is no apparent evidence of normal motion along the planes. The variations in rock types across the d'Abbadie fault zone show 
Figure 21. Faults in the d'Abbadie fault zone. (a) Structural map showing the location of the faults within in the d'Abbadie fault zone (see Figure 10 for the structural domain map). The faults are generally northwest-striking. Another set of faults are apparently north-striking and diverge away from the framing faults. (b) Looking south, along strike at a steeplydipping exposure of the d'Abbadie fault zone located approximately 15 kilometres to the south of the study area. The height of exposure is approximately $300 \mathrm{~m}$ (modified after Colpron 2005) and is marked by a highly noticeable rusty orange-brown colour compared to the adjacent rocks. Rocks to the east are from the Last Peak succession and the ones to the west are part of an ultramafic massif of the Mendocina succession. (c) The average orientation of the faults in the d'Abbadie fault zone is $169 / 84 \mathrm{SW}$. They form the frame of the fault zone. (d) Other measured shear fractures are northeast-striking and have an average orientation of $058 / 88 \mathrm{SE}$. Note that these do not show up at the map-scale. 

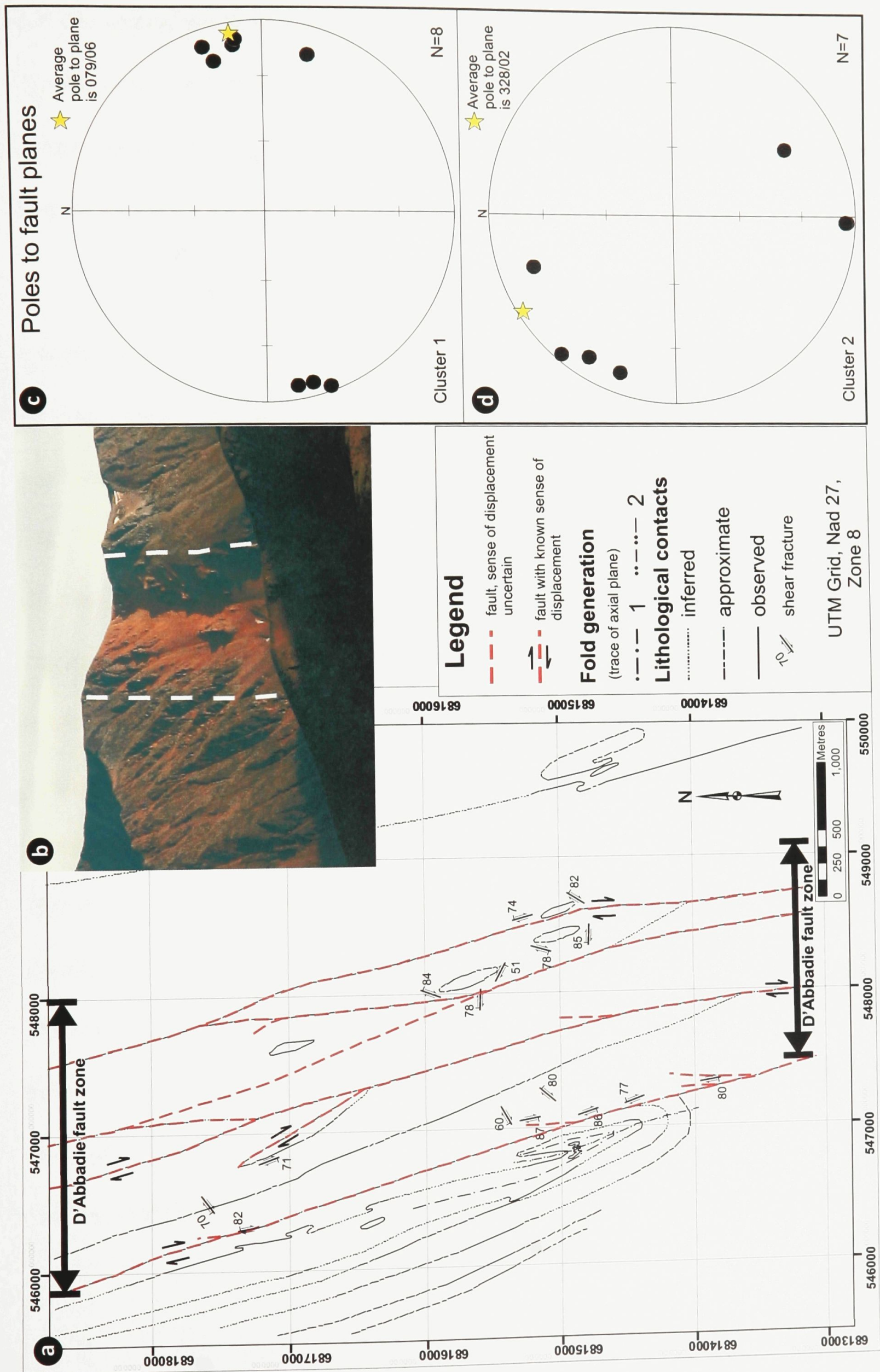

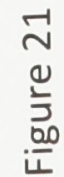


that the walls of the faults are not homogeneous. Rather they comprise multiple and variable panels of fault rocks (e.g. Cataclastic, Mixed or Fracture domain) characterized by their specific brittle structures (e.g. cataclasites; localized cataclasites, fractures, or breccia; and shear fractures).

The faults in the field are far to resemble lines on a map. The fault contacts are not exposed, but have been inferred based on the distribution of the cataclasites, the outcrop control throughout the d'Abbadie fault zone, and from the way that rock units are truncated. The faults in the d'Abbadie fault zone occur in two main orientations (Fig. 21a). The orientation of the faults on the map is based on the structural measurements of seven representative shear fracture plane orientations in the d'Abbadie fault zone. The average orientation of the predominant set of faults, i.e. those controlling the fault pattern of the d'Abbadie fault zone, is $169 / 84$ SW (Fig. 21c). Other faults are northstriking and are shown on the map. Lastly, other measured shear fractures are northeast-striking with an average orientation of 058/88 SE (Fig. 21d). The latter are absent from the map because they only occur at the $\mathrm{cm}$-scale within outcrops. The significance and timing of these shear fractures is unclear, but they have similar orientations to northeast-striking faults recognized regionally by Colpron (2005b) and de Keijzer (2000) that cut $\mathrm{S}_{\mathrm{t} 2}$ and the d'Abbadie fault. Hence, the northeast-striking shear fractures in this study are interpreted to be concordant with the faults recognized by Colpron (2005b) and de Keijzer (2000), and to cross cut the d'Abbadie fault zone. 
The western edge of the fault zone is abrupt as it is marked by a fault. The eastern edge of the fault zone is gradual as the Fracture domain marking the eastern edge gradually diminishes into the rocks that were not deformed in the d'Abbadie fault and considered outside the fault zone.

\subsubsection{Mylonitic elements in the Last Peak granite}

The mylonitic rocks in the Last Peak granite are defined by mylonitic elements such as the C-planes, S-planes and a lineation. In this study, the author refers to the mylonitic foliation (C-plane) as $S_{m y 2}$, i.e. "my" for mylonitic and "2" for a mylonitic foliation that differs from $S_{m y 1}$ in the Mendocina orthogneiss. It also differs from and post-dates $\mathrm{S}_{\mathrm{t} 2}$. This is based on the cross-cutting contact relationship of the Last Peak granite with $\mathrm{S}_{\mathrm{t} 2}$, the rock units of the Last Peak succession and the Mendocina orthogneiss. Similarly, the lineation is referred to as $L_{m y 2}$.

The orientation of these mylonitic elements has been measured at 28 stations in the Last Peak granite. For clarity, only selected measurements of $S_{m y 2}$ and lineation $L_{m y 2}$ are shown on the map (Fig. 22a). The poles of measured C-planes are plotted on a lower hemisphere equal-area stereonet in Fig. 22b. The average C-planes have an orientation of 333/84 NE. The poles of measured S-planes are plotted on stereonet in Fig. 22c. The average orientation of the S-planes is $320 / 84$ NE. Shallowly plunging quartz stretching lineations form a single cluster, with variations in plunge to the northwest or southeast (Fig. 22d). Their average orientation is $01 / 333$ NW. 
Figure 22. Mylonitic rocks in the Last Peak granite. (a) Structural map showing the location of measured shear planes ( $C$-planes) and stretching lineations taken throughout the three domains in the Last Peak granite. The inset map shows the location of the Last Peak granite within the d'Abbadie fault zone. (b) Stereogram of poles to C-planes shows an average pole orientation of 063/06 NE, which is equivalent to an average C-plane orientation of 333/84 NE. (c) Stereogram of quartz stretching lineations shows an average orientation of 01/333. 


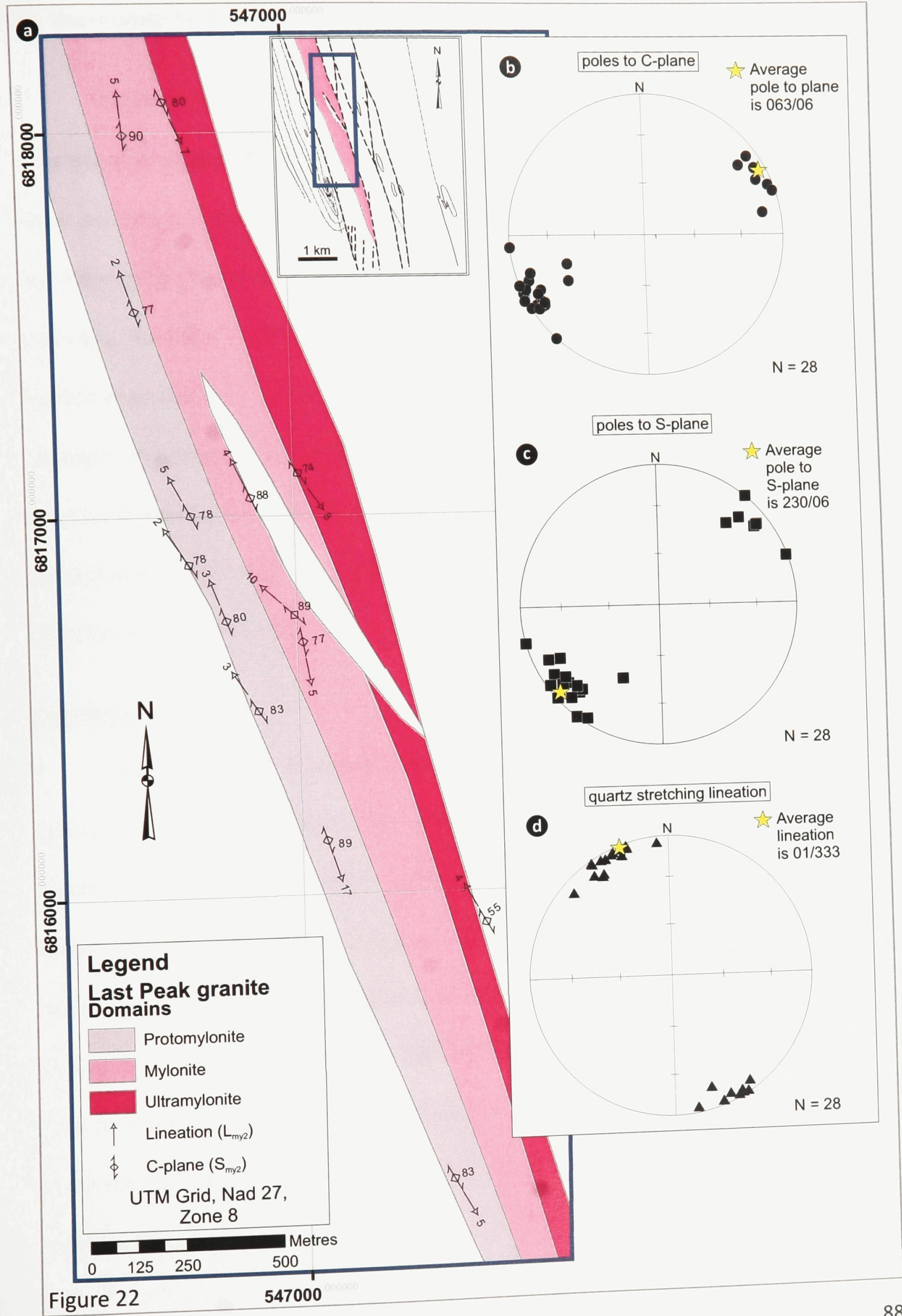

Figure 22 


\subsection{Shear sense indicators}

The sense of displacement along faults may be determined from the geometry of a variety of structures and microstructures in the fault rocks referred to as sense of shear indicators. These indicators, their origins and significance are extensively described in the literature from both brittle (cataclastic) and ductile (mylonitic) fault rocks (e.g. Berthé et al. 1979; Lister and Snoke 1984; Passchier and Simpson 1986). This section describes the structures and microstructures that can be used as shear sense indicators in cataclastic and mylonitic rocks of the d'Abbadie fault zone. These form the basis for interpreting the sense of displacement along the d'Abbadie fault zone presented in Section 4.2. Shear sense indicators are defined here according to Passchier and Trouw's (1996) classification.

\section{Cataclastic rocks}

The combination of stepped surfaces and slickenlines on fault planes provides tools to reconstruct part of the displacement history of a fault, as slickenlines tend to record the last direction of slip on a fault surface, and stepped surfaces generally step down towards the direction of slip of respective fault blocks (Davis and Reynolds 1997). Shear sense indicators in the cataclastic rocks of the d'Abbadie fault zone include slickenlines (Fig. 23) combined with stepped surfaces on an approximately $10-20 \mathrm{~cm}^{2}$ area of polished surfaces on the fault planes. The average orientation of the fault planes is 169/84 SW (Fig. 21c). The slickenlines occur as shallowly plunging groove marks on the fault planes and trend to the northwest. Stepped surfaces are oriented 


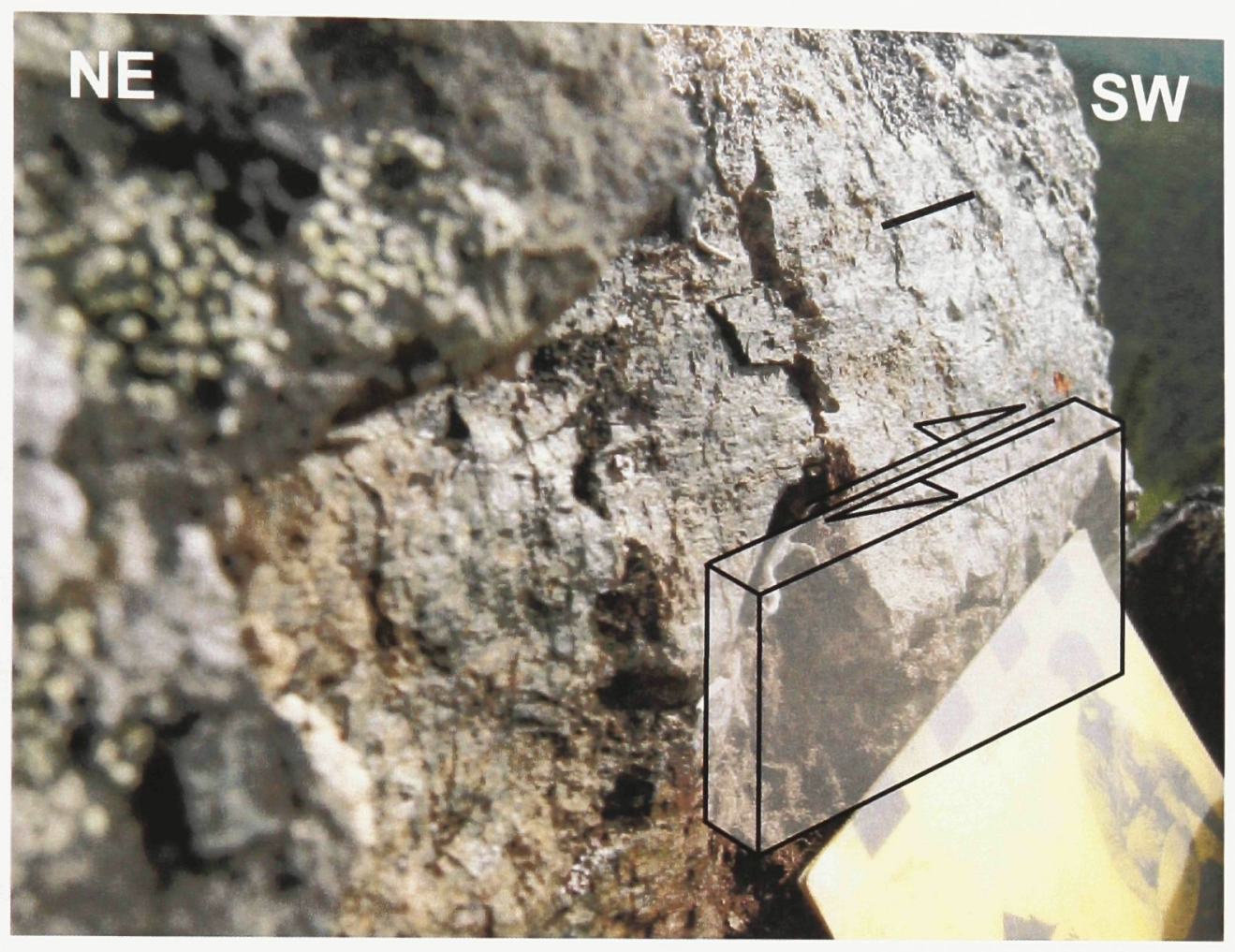

Figure 23. Brittle structure that overprints a chlorite schist from the Mixed domain in the d'Abbadie fault zone. The photograph was taken looking to the southeast and shows a steeply dipping chlorite-coated fault plane with shallowly plunging slickenlines (black line) and stepped surfaces oriented perpendicular to the lineation that are interpreted to step down to the northwest. The orientation of the stepped surfaces on the block suggests dextral motion of shear. The block represents the orientation of the fault surface and the opposing side of the fault. The surface has shallowly plunging slickenlines. 
perpendicular to the shallowly plunging slickenlines and step down to the northwest. Altogether, the orientation of the slickenlines and stepped surfaces suggest that they formed from the relative dextral horizontal movement of planes (Berthé et al. 1979). Similarly, chlorite-coated brittle faults with step-fibres observed by Colpron (2006b) are also consistent with a dextral sense of shear.

\section{Mylonitic rocks}

The geometry of S-C mylonites is often explained by the progressive simple shear deformation of a circle resulting in an ellipse (Fig. 24a) (Ramsay and Hubert 1983, Passchier and Trouw 1996) in two-dimensional space (X, Y). This is where the long axis of the ellipse is concordant with the orientation of the axis of maximum extension, which rotates towards the $\mathrm{X}$-axis with progressive deformation, and the $\mathrm{X}$-axis has a constant orientation (Berthé et al. 1979). This concept of ellipse and associated axes are best observed in the motion plane (Fig. 24b) - the plane containing the trace of planar anisotropies such as the schistosity (S-plane) and shear planes (C-plane), and that is perpendicular to the shear foliation and parallel to the stretching lineation. The initial angle that forms between the S-plane and C-plane is at $45^{\circ}$ (Berthé et al. 1979), decreases with progressive deformation, and results in the rotation of the S-plane towards the C-plane (Berthé et al. 1979). Thus the sense of rotation of the S-plane towards the C-plane can be used to deduce the sense of shear. From two-dimension to three-dimension, the strain ellipse becomes a strain ellipsoid. The strain ellipsoid is defined by three axes: the axes of maximum extension (S1) and minimum extension (S3) 
Figure 24. Notions of simple shear and motion plane for the mylonitic rocks in the Last Peak granite. (a) Simple shear in two-dimensions is expressed by the rotation and distortion of a circle into a strain ellipse. Like the long axis of a strain ellipse, the schistosity (S-plane) contains the axis of maximum extension (S1) and initiates at $45^{\circ}$ with respect to the coordinates $(X, Z)$. With progressive deformation, the S-plane rotates towards the shear plane (C-plane), the axis of minimum extension (S3) shortens, and the angle between the Splane and C-plane decreases (modified after the course notes of Waldron 2010). (b) Looking at the motion plane of a mylonite from the Last Peak granite. The orientation of the S-plane with respect to the C-plane, in two-dimension, suggests dextral sense of shear. (c) Hand sample of mylonite from the Last Peak granite showing the relationship between the mylonite structural elements, in a three-dimension perspective. (1) Motion plane containing the trace of S- (blue) and C-planes (black), and porphyroclasts (blue) concordant with the Splane. (2) The C-plane is perpendicular to the motion plane, concordant with the stretching lineation, and contains the trace of the stretching lineation (red line). (3) Plane perpendicular to the $\mathrm{C}$-plane and the stretching lineation. It contains traces of C-planes (white line) and cross sections (black ellipse) of predominantly lengthened to moderately flattened porphyroclasts (see Section 4.2). 
a Strain ellipse
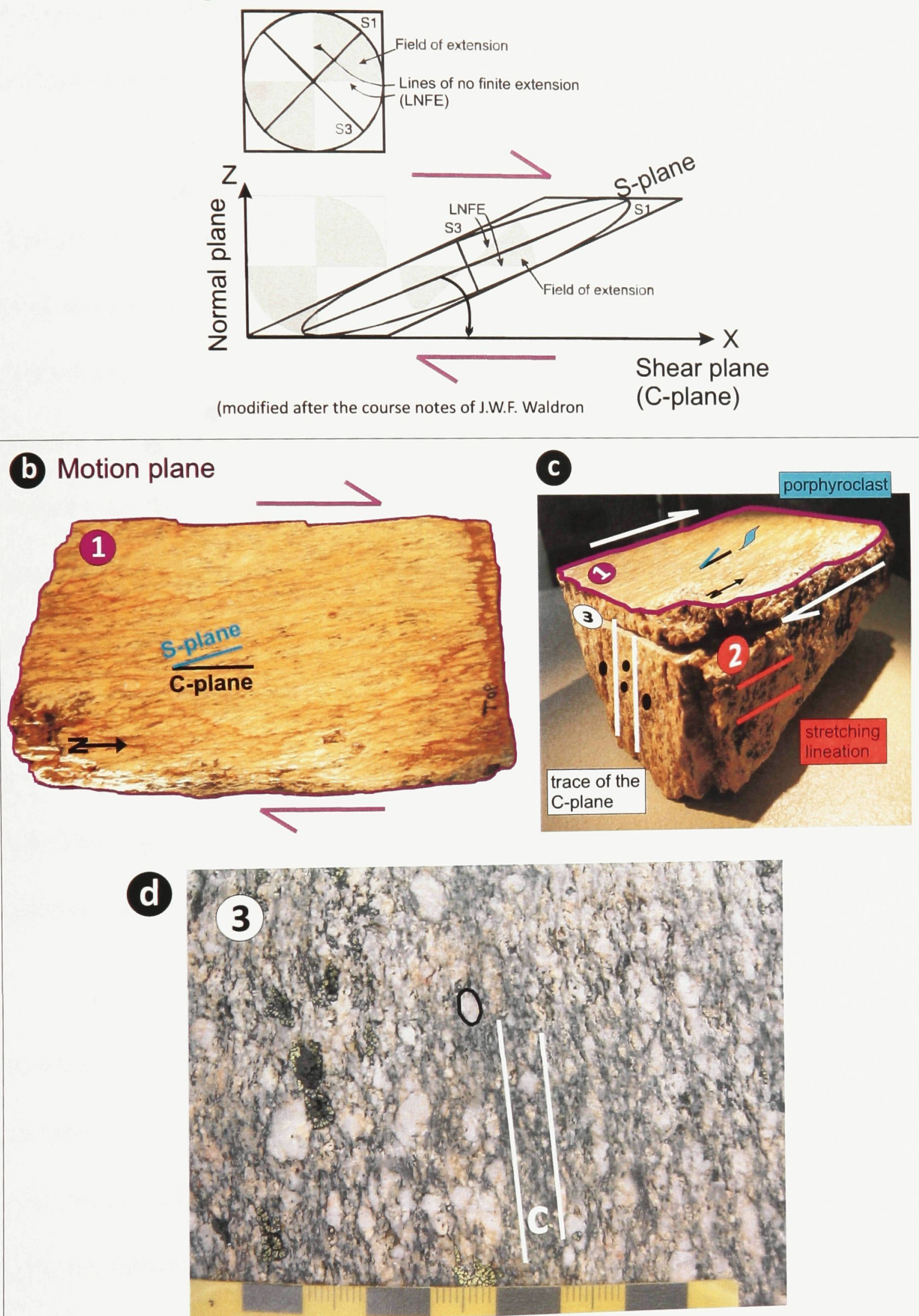

Figure 24 
which fall within the motion plane like in the strain ellipse, and the axis where no deformation occurs along its direction (S2). S2 is perpendicular to $\mathrm{S} 1$ and $\mathrm{S} 3$, and is concordant with the S-plane.

The best estimate of the sense of displacement for the mylonitic rocks in the Last Peak granite is interpreted from an analysis of structures in both two-dimensions and three-dimensions, by looking at i) the motion plane (Fig. 24b, c1); and at ii) the whole rock volume (Fig. 24c) from 28 locales. From the Protomylonite to the Ultramylonite domain, the S- and C-planes are NW-SE striking and steeply dipping, the S-plane rotated towards the C-plane and the angle between the two gradually decreased so that the Splane became almost concordant with the C-plane. The NW-SE striking traces of the Sand C-planes when looking in the motion plane, the NW or SE trending and shallowly plunging stretching lineation, and the consistent clockwise sense of rotation between of the S-plane towards the C-plane throughout the domains (see Section 3.1.2, Fig. 17a, 18a, 19a) together with the steeply dipping S- and C-planes throughout the whole rock volume are interpreted as dextral.

In three-dimensions, the information gathered from the motion plane is combined with observation of the plane perpendicular to the motion plane and the stretching lineation (Fig. 24d). Shallowly plunging quartz stretching lineations (average orientation; 01/333) (Fig. 24c2) and are interpreted to show shallow horizontal motion of shear within the C-plane that generally keeps a constant northwest-southeast orientation. On the plane perpendicular to the motion plane and the stretching lineation 
(Fig. 24c3), traces of the C-plane are steep. The generally equant in shape to weakly oblate porphyroclasts (Fig. 24d) are concordant with the lineation.

More information may be taken from the S-plane, as minerals deforming within this plane record kinematic and deformation aspects of the kinematic history of the mylonitic rock (Passchier and Trouw 1996). These minerals, often megacrysts bordered by pressure shadow domains are porphyroclast systems (Passchier and Simpson 1986) referred to as kinematic indicators or sense of shear indicators. In the Last Peak granite, the relationship where the long axis of K-feldspar porphyroclasts oriented in the S-plane with the long axis of asymmetric tails (pressure shadows) oriented in the C-plane (Fig. $25 a)$ is pervasive throughout all the domains. Other common occurrences are biotite fish (Fig. 25b) and locally muscovite fish. Antithetic microfaults in K-Feldspar porphyroclasts (Fig. 25c) are sparsely found throughout all domains, but are more common in the western domain. Passchier and Trouw (1996) suggest that antithetic microfaulting should only be considered as a potential sense of shear marker, and not as a main marker, because their reliability is uncertain. Antithetic microfaults are commonly observed in the d'Abbadie fault zone; they are consistently in agreement with other kinematic indicators observed in the rocks.

Altogether, the relationship of the S-plane with the C-plane and stretching lineation, and kinematic indicators observed in S-C mylonites are consistent with dextral sense of shear. Observations and results, pertaining to kinematic analysis, from previous 
Figure 25. Shear sense indicators and potential shear sense markers from mylonitic fault rocks in the d'Abbadie fault zone. (a) Photomicrograph of an asymmetrical sigma-type porphyroclast of $\mathrm{K}$-feldspar showing its orientation in the S-plane and its fine-grained quartz-filled strain shadows oriented in the C-plane - FOV $2 \mathrm{~mm}, 10 \mathrm{x}$, crossed polars. (b) Photomicrograph of a mylonite. Biotite mica-fish and the long diagonal of K-feldspar porphyroclasts are contained within the S-plane. Their orientation with respect to the Cplane is interpreted to show dextral sense of shear (refer to Section 4.2 for interpretation). - FOV $8 \mathrm{~mm}, 2.5 \mathrm{x}$, crossed polars. (c) Antithetic microfaulting in a K-feldspar porphyroclast contained in a biotite-feldpar-quartz matrix of a protomylonite in the Last Peak granite FOV $2 \mathrm{~mm}, 10 \mathrm{x}$, crossed polars. 

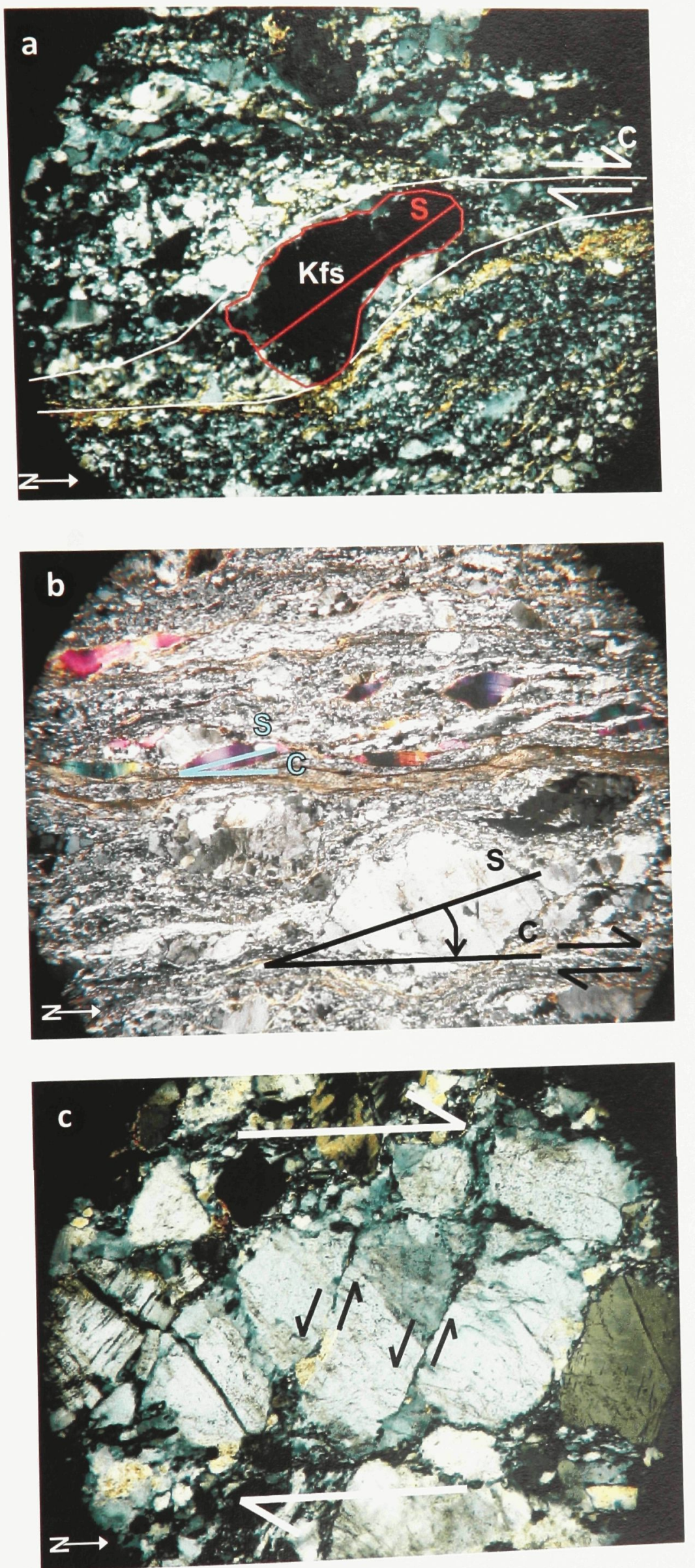

Figure 25 
studies (e.g. Hansen 1989; Harvey et al. 1997; Gallagher et al. 1998; Gallagher 1999; de

Keijzer 2000; Colpron 2005, 2006) are also in agreement with the results of the kinematic analysis of this study.

\subsection{Metamorphic mineral occurrences in the d'Abbadie fault}

Chlorite occurs along $\mathrm{S}_{\mathrm{t} 2}$ in rocks of the Last Peak succession (e.g. map unit B, C and G in Fig. 6) throughout the d'Abbadie fault zone has crystallized from upper greenschist to lower amphibolites facies metamorphism during regional deformation (Gallagher 1999; de Keijzer 2000). Such chlorite has crystallized in the Permo-Triassic (Berman et al. 2007), pre-dates the d'Abbadie fault zone and is therefore not the focus of this study.

Another generation of chlorite occurs along structures and microstructures of the cataclastic and mylonitic rocks in the d'Abbadie fault zone. Like other metamorphic minerals, chlorite may be a useful indicator of the conditions of deformation for a particular system. In the cataclastic rocks, chlorite is found as a mineral coating fault planes and shear fracture surfaces, which is interpreted to have crystallized during motion along the planes; as a matrix mineral in cataclasite zones; and with quartz and calcite in veins. In the mylonitic rocks localized in the Last Peak granite, chlorite occurs in the form of strain fibers in pressure shadows of K-feldspar porphyroclasts within the mylonites. The porphyroclasts were rotated into concordance with the mylonitic foliation $\left(\mathrm{Sm}_{\mathrm{y} 2}\right)$ during deformation of the Last Peak granite, so chlorite in the pressure shadows is interpreted as syn-kinematic. 


\subsection{Summary}

The d'Abbadie fault zone in a $5 \times 6 \mathrm{~km}$ study area is a $2 \mathrm{~km}$-wide, steeply dipping, and northwest-striking strike-slip fault zone that truncates steeply dipping and northwest-striking polydeformed supracrustal rocks of the Last Peak succession, $\mathrm{S}_{\mathrm{t} 2}$, and intrusive rocks such as the Mendocina orthogneiss and Last Peak granite (Fig. 6). The d'Abbadie fault zone post-dates the regional metamorphic, polyphase folding deformation, and Early Jurassic cooling history.

The d'Abbadie fault zone is made of multiple anastomosing, northwest- to northstriking, and steeply dipping strike-slip faults that are filled with 2-30 m-wide cataclasites. The fault walls are composed of a mixture of cataclasites, fractures, and locally breccias. The boundaries of the fault zone are controlled by anastomosing and steeply dipping brittle faults that predominantly strike to the northwest.

The rocks in the d'Abbadie fault zone are cataclastic and fractured rocks that developed primarily in the Last Peak succession (Fig. 26), and locally the Mendocina orthogneiss and Last Peak granite. It also has a 200-500 m-wide strand of mylonitic rocks restricted to the Last Peak granite (Fig. 26). The cataclastic and fractured rocks comprise three domains: the Cataclasite, Mixed and Fracture domains. The Last Peak granite is composed of S-C mylonites which comprises three domains: the 
Figure 26. Map showing the distribution of cataclastic and fractured rocks with respect to mylonitic rocks in the d'Abbadie fault zone. The cataclastic and brittle rocks form most of the fault zone and are dominantly hosted in the supracrustal rocks of the Last Peak succession (see Figure 6 for the geology map of the study area). The mylonitic rocks are localized and restricted to the Last Peak granite. 


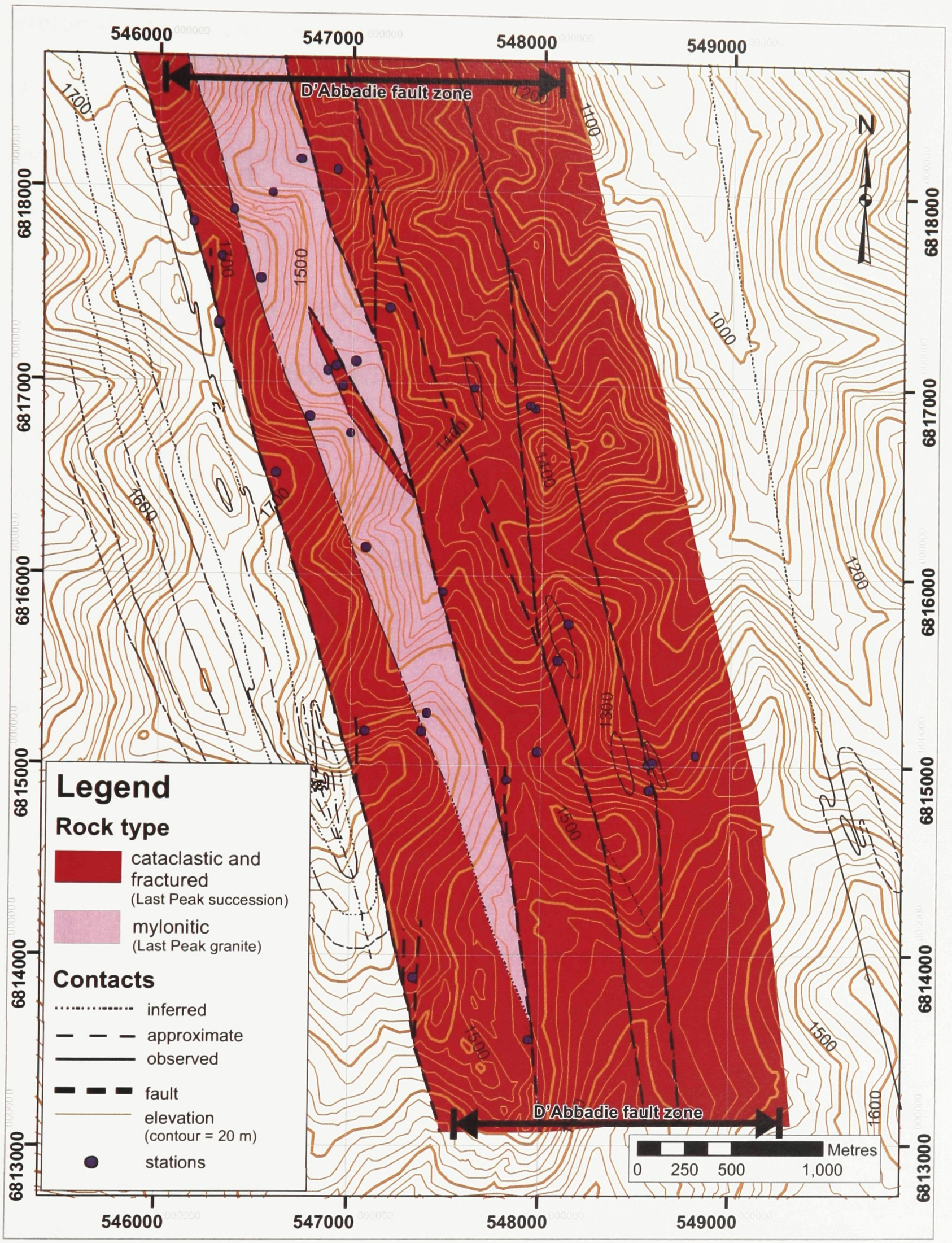

Figure 26 
Protomylonite, Mylonite, and Ultramylonite domains (Fig. 16). The Protomylonite domain is the furthest from the center of the fault zone. In the eastward direction, this domain gives way to the Mylonite domain, which in turn gives way to the Ultramylonite domain.

In mylonitic rocks, grain size, the angular relationship between C- and S-planes, and spacing between the C-planes decreases from west to east, while percentage of matrix with respect to porphyroclasts and overall development of mylonitic fabric elements increase. This suggests a strain gradient, with strain increasing from west to east across the 200-500 m width of the Last Peak granite.

S-C mylonites are characterized by steeply dipping, northwest-striking C- and Splanes, and northwest-trending and shallowly NW- and SE-plunging quartz stretching lineation. Shear sense indicators in both cataclastic and mylonitic fault rocks are consistent with a dextral sense of shear. This is based on the orientation of stepped surfaces orthogonal to shallowly plunging slickenlines on fault planes; the orientation of S-planes with C-planes and their relationship with the stretching lineations; and the orientation of lengthened porphyroclasts in the S-plane with respect to the C-plane.

Finally, the cataclastic and mylonitic rocks in the d'Abbadie fault zone are often associated with chlorite. Chlorite is coating shear fracture plane surfaces in the d'Abbadie fault zone and occurs in strain shadows of K-feldspar porphyroclasts in mylonites in the Last Peak granite. 
SECTION 4 - DISCUSSION AND IMPLICATIONS 
The purpose of this section is to evaluate and integrate all the evidence from the previous sections to determine the history of the d'Abbadie fault zone. These data show that the d'Abbadie fault zone has a complex internal architecture. The Last Peak granite also plays an important role in the history of the d'Abbadie fault zone. It helps to constrain the sense and timing of displacement of the d'Abbadie fault zone. Cataclastic and fractured rocks throughout the fault zone give the best estimate for the deformation regime, rheology, crustal conditions, and metamorphic grade at the time of deformation. This section also shows that the d'Abbadie fault zone did not undergo reactivation.

\subsection{Cataclastic and fractured rocks in the d'Abbadie fault zone}

As proposed by Ramsay and Graham (1970), the lithology often controls the style of the structures that developed during deformation. On the basis of the descriptions of the structures and rocks cutting across the supracrustal rocks of the Last Peak succession (see Section 3.1), the d'Abbadie fault zone consists mostly of cataclastic and fractured rocks. Based on the distribution of the rocks within the fault zone, this study suggests that the distribution of the fault rocks is lithologically controlled by the rheology of the rocks of the Last Peak succession or the rheology contrast of this succession with the Mendocina orthogneiss and the Last Peak granite. For example, the cataclasites are found mostly in phyllite (e.g. map unit E) and schist (e.g. map unit G), but also at the edge of the western contact of the Mendocina orthogneiss and the eastern contact of the Last Peak granite. The structures in the Mixed domain occur throughout the map units in general. The fractures in the Fracture domain occur away 
from the faults, and the breccias were only found in the dolomitic marble (e.g. map unit D).

\subsection{The Last Peak granite is syntectonic with the d'Abbadie fault zone}

This section touches on several aspects of the Last Peak granite that altogether suggest that emplacement of the Last Peak granite was syntectonic with respect to motion along the d'Abbadie fault zone. Evidence includes primary contact relationships, restriction of mylonitic rocks to within the granite, and the presence of a ductile strain gradient within mylonites of the Last Peak granite.

The contact (see Section 2.3.1) between the Last Peak granite and rocks and structures of the Last Peak succession are exposed along the western edge of Last Peak granite. Undeformed apophyses with chilled margins of the Last Peak granite cut across $\mathrm{S}_{\mathrm{t} 2}$ in the rocks of the Last Peak succession containing upper greenschist facies metamorphic minerals (Harvey 1996; Gallagher 1999). S $\mathrm{S}_{\mathrm{t} 2}$ foliation in a marble raft within the Last Peak granite is cut by the intrusive contact and overprinted by $S_{\text {my2 }}$. This same marble raft also has a contact aureole which also overprints the $\mathrm{S}_{\mathrm{t} 2}$ foliation within the raft.

Mylonites (e.g. S-C mylonites) are restricted to the 200-500 m-thick Last Peak granite whereas brittle structures are pervasive throughout the rest of the $2 \mathrm{~km}$ thick d'Abbadie fault zone in the Last Peak succession rocks. The localization of ductile structures to the Last Peak granite can be explained if the Last Peak granite rocks were weak because they were at temperatures above the brittle-ductile transition. Such 
weakness ultimately facilitated the development of the ductile structures. The development of these structures (e.g. S-plane, C-plane, and lineation) could perhaps have occurred syn- to early post-intrusion; while the approximated pluton temperature was up to $650{ }^{\circ} \mathrm{C}$, based on the standard wet granite temperature in water-saturated conditions (Tuttle and Bowen 1958) to $350-250^{\circ} \mathrm{C}$, and prior to its rapid cooling while intruding.

The ductile strain gradient increasing eastward towards the eastern margin of the pluton is interpreted as an increase in finite strain (Berthé et al. 1979). Ultimately, the protomylonites in the Protomylonite domain are the furthest from the center of the fault zone are interpreted to have undergone the least strain with respect to the other domains. These protomylonites give way to mylonites in the Mylonite domain. Ultramylonites in the Ultramylonite domain are the closest to the center of the fault zone and are interpreted to have deformed under the highest strain. This increase in finite strain can be explained if higher strain was concentrated in the center of the fault zone (Ramsay and Graham 1970). Perhaps the mylonitic rocks in the Last Peak granite have formed contemporaneously with the displacement of the d'Abbadie fault zone. This could also suggest that the fault strand bounding the Last Peak granite to the east was active at the time of intrusion of the pluton. This is consistent with interpretations of Harvey et al. (1997) and Colpron (2006b).

4.3 Sense and estimate of the magnitude of displacement on the d'Abbadie fault zone 
Northwest-striking and steeply dipping structures and microstructures in mylonitic rocks in the syntectonic Last Peak granite, the relative near horizontal motion on brittle shear fracture planes throughout the fault zone, and the near horizontal plunges of associated lineations indicate that the d'Abbadie fault zone is a dextral strikeslip fault. As for the magnitude of displacement, Gallagher (1999) identified a km-scale, NW-trending fold hinge on the eastern side of the d'Abbadie fault zone in the Dycer Creek area. He proposed that the fold hinge is a prime candidate for a piercing point; however no corresponding fold hinge was identified on the western side of the fault zone. Alternatively, the minimum differential displacement on the d'Abbadie fault zone may be estimated by using Ramsay's (1979) calculation technique of displacement, provided that one deals with a ductile shear zone and assuming simple shear conditions of deformation. This calculation technique consist of the equation $\mathbf{s}=\mathbf{Z} \tan \psi$; where $\mathbf{s}$ is the total differential displacement, $\mathbf{Z}$ is the estimated thickness of the Last Peak granite in the east-west direction, and $\psi$ is the angular shear strain, i.e. the estimated angle that the Last Peak granite makes with the east-west direction $\mathbf{Z}$. In this study, we use the ductile Last Peak granite. The best estimate of displacement is 7.6 kilometres, assuming a thickness of $2.5 \mathrm{~km}$ and angular shear strain of $72^{\circ}$. These estimations were taken from a range of thicknesses $(250 ; 500 ; 1000 ; 2500 ; 5000 ; 8000 \mathrm{~m})$ and angular shear strains $\left(45 ; 60 ; 65 ; 70 ; 72 ; 80 ; 85^{\circ}\right)$, and are presented in Table 5 . This estimation of the displacement though only accounts for the ductile displacement along the d'Abbadie fault zone and is interpreted as a minimum displacement. Similarly, Harvey et al. (1996) 
Table 5. Estimation of a portion of the displacement on the d'Abbadie fault zone.

\begin{tabular}{|c|rrrrrr|}
\hline W: assumed angular & \multicolumn{6}{|c|}{ Z: assumed thickness (metres) } \\
\cline { 2 - 8 } shear strain (degrees) & \multicolumn{1}{|c|}{250} & 500 & 1000 & 2500 & 5000 & 8000 \\
\hline 45 & 250.00 & 500.00 & 1000.00 & 2500.00 & 5000.00 & 8000.00 \\
60 & 433.01 & 866.03 & 1732.05 & 4330.13 & 8660.25 & 13856.41 \\
65 & 536.13 & 1072.25 & 2144.51 & 5361.27 & 10722.53 & 17156.06 \\
70 & 686.87 & 1373.74 & 2747.48 & 6868.69 & 13737.39 & 21979.82 \\
72 & 769.42 & 1538.84 & 3077.68 & 7694.21 & 15388.42 & 24621.47 \\
80 & 1417.82 & 2835.64 & 5671.28 & 14178.20 & 28356.41 & 45370.25 \\
85 & 2857.51 & 5715.03 & 11430.05 & 28575.13 & 57150.26 & 91440.42 \\
\hline
\end{tabular}

$\mathrm{s}=\mathrm{Z} \tan \psi$

$\mathrm{s}$ : displacement (metres)

$Z$ : assumed thickness (metres)

$\psi$ : angular shear strain (degrees)

The green box contains the number for the best estimate of a portion of the displacement on the d'Abbadie fault zone, which is $7.6 \mathrm{~km}(7694.21 \mathrm{~m})$. The portion of the displacement represents the ductile displacement from the Last Peak granite.

See text in section 4.3 for the details. 
suggest magnitude of displacement of 4 kilometres based on the offset of lithologic contacts. The entire magnitude of displacement of the fault zone is uncertain.

The characterization of structures and microstructures for mylonitic rocks, by considering the two-dimensional space (e.g. motion plane showing the trace of the Sand C-planes) together with the three-dimensional space by considering the volume of rock, the S-plane, C-plane and the lineation, serves to get the best estimate of the conditions of deformation in a rock. It also serves to best estimate the state of strain, i.e. the final state of a body resulting from all previous appearance of a body (e.g. mylonite) at a given time (Twiss and Moores 2007). The mylonitic rocks in the Last Peak granite have undergone progressive simple shear deformation. The best evidence consists of the concordance between the shear planes (C-plane) and the $X$ axis of the strain ellipse, together with plane strain. Although, the potential for a minor triaxial component during deformation cannot be ruled out (e.g. slightly oblate K-feldspar porphyroclasts), field descriptions of the porphyroclasts together with microstructural observations best show evidence for near plane two-dimensional strain (Fig. 27).

\subsection{Timing of displacement on the d'Abbadie fault zone}

Ductile structures such as mylonitic rocks in the Last Peak granite and the strain gradient suggest that the Last Peak granite intruded during deformation along the d'Abbadie fault zone. U/Pb crystallization ages of ca. $96 \mathrm{Ma}$ for igneous monazites (Gallagher, 1999) from the Last Peak granite, therefore suggest that at least part of the displacement on the d'Abbadie fault zone occurred at ca. $96 \mathrm{Ma}$. This age is consistent 


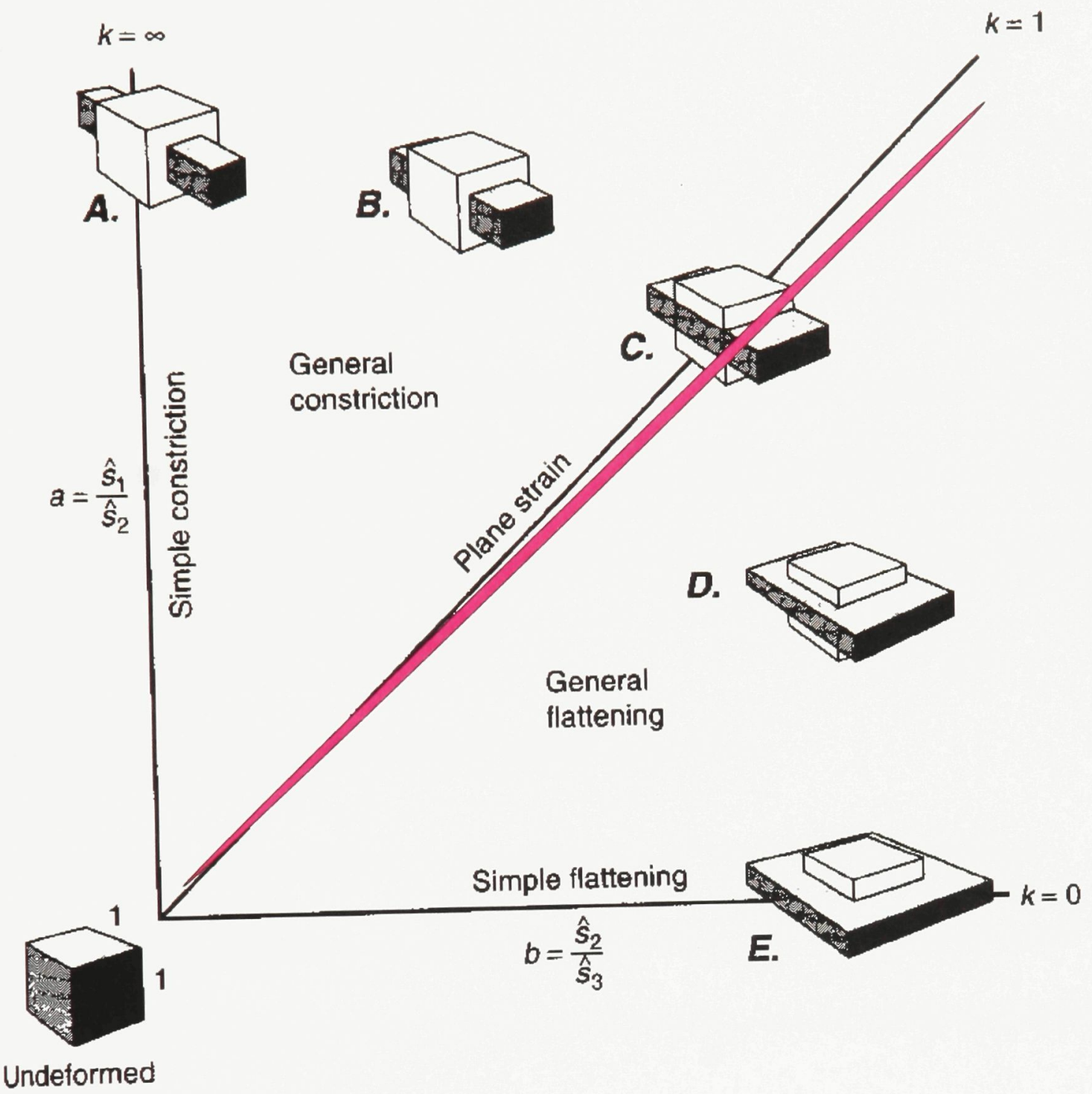

Figure 27. The best estimate of plane simple shear strain deformation with minor general flattening (pink ellipse) with respect to the Flinn diagram for constant volume deformation (Introduced by the British geologist Derek Flinn 1962). 
with ${ }^{40} \mathrm{Ar} /{ }^{39} \mathrm{Ar}$ ages of muscovites near the fault of ca. $97 \mathrm{Ma}$ (Hansen et al. 1991) interpreted as deformation ages and ${ }^{40} \mathrm{Ar} /{ }^{39} \mathrm{Ar}$ ages of muscovites in the Mendocina orthogneiss of ca. $97 \mathrm{Ma}$ (see Appendix; this study). Localized cataclasite zones, slickenlines on fault polished surfaces, and fractures overprint the S-C mylonites in the Last Peak granite. These crosscutting relationships, also observed by Colpron (2006b), suggest that brittle faulting outlasted cooling of the granite and ductile deformation. Therefore, the d'Abbadie fault has been active since at least ca. $96 \mathrm{Ma}$ and for some (?) time after, but the absolute age bracket of when faulting began and waned is uncertain. One may wonder if there is potential evidence for reactivation of the fault through time and this topic is addressed in Section 4.8.

\subsection{Retrograde metamorphism in the d'Abbadie fault zone}

This discussion is restricted to the d'Abbadie fault zone and minerals that crystallized during deformation along the d'Abbadie fault zone - not to be confused with regional metamorphic chlorite that crystallized in the Permo-Triassic and cooled in the Early Jurassic.

Retrograde metamorphic reactions are common in fault zones, because faults and fractures that form during deformation represent low-pressure sites, which in turn promote fluid circulation that is beneficial for these reactions to occur (Vernon, 2004).

The localization of chlorite in the d'Abbadie fault zone, including local areas in the eastern edge of the Last Peak granite, suggests that it precipitated during deformation in the fault zone and is therefore syn-structural. This is based on chlorite 
coating fault surfaces that proved to be concordant with both the orientation and sense of displacement of the d'Abbadie fault zone. Other evidence consists of chlorite strain fibers that occur in strain shadows of K-feldspar porphyroclasts only at the eastern edge of the Last Peak granite, interpreted to have formed by pressure solution. These porphyroclasts, which are primarily associated with quartz and biotite, throughout the Last Peak granite (with the exception of the eastern edge) are associated with chlorite. Such chlorite is in turn interpreted to have replaced biotite.

The best estimate of the metamorphic facies for the cataclastic metasedimentary rocks in the d'Abbadie fault zone is greenschist facies (Spear 1993), on the basis of the occurrence of chlorite in localized brittle structures; and chlorite localized in the syntectonic Last Peak granite.

\subsection{Deformation regime, rheology and indicators of depth-temperature conditions}

This section provides the basis for the interpretation of the deformation regime, the rheology and indicators of depth-temperature conditions for the d'Abbadie fault zone. Finally, this section presents the temperature conditions for the formation of the $\mathrm{S}-\mathrm{C}$ mylonites in the Last Peak granite.

4.6.1 Deformation regime and rheology in the d'Abbadie fault zone

On the basis of the brittle structures and microstructures observed in the d'Abbadie fault zone, this study demonstrates that formation of cohesive cataclasites in the Cataclasite zone, Mixed zone, and locally in the Last Peak granite proceeded by brittle deformation mechanisms. Brittle deformation mechanisms include: cataclastic 
flow in and between grains, frictional grain-boundary sliding and pressure solution, termed as stress-induced solution transfer (Passchier and Trouw 1996). Cataclastic flow is the mechanical fragmentation, with subsequent sliding and rotation of fragments (Passchier and Trouw 1996), and is indicated by the sharp angular and irregular shape of clasts and rock fragments; variably-sized and randomly oriented clasts; and microcracks in feldspar and quartz. One may argue that cataclastic flow is a ductile deformation mechanism, because coherency is maintained the hand sample scale, but as pointed out by Vernon (2004), it depends on the scale of observation. Micro-scale fracturing which is governed by frictional deformation mechanisms in rocks with cataclastic flow should therefore be treated as a brittle deformation process (Fig. 12d). Frictional grainboundary sliding is indicated by the sliding of grains past each other along microfaults, and stress-induced solution transfer is indicated by grain boundary bulging and stylolitic grain boundaries (Fig. 15d). As for the rocks in the Fracture zone, they have undergone brittle fracturing rather than cataclasis, meaning that the resulting deformation is expressed as fractures - surface where material loses cohesion (Twiss and Moores 2007). Shear fractures form from confining compression, have minor displacement along their planes and form without mechanical fragmentation of the rocks in comparison to cataclasites (Twiss and Moores 2007).

Deformation mechanisms forming brittle structures and microstructures in the cataclastic rocks of the d'Abbadie fault zone (including local cataclasites in the Last Peak granite) are characteristic of and consistent with a brittle deformation regime. Such 
brittle regime and cataclastic rocks are indicative of the rheology of a brittle crust (Fig. 28).

4.6.2 Syntectonic depth-temperature indicators

Microstructural study of minerals in fault rocks can provide indication of syntectonic temperatures (Stewart et al. 1999). The occurrence of cohesive brittle fault rocks showing cataclastic flow, frictional grain-boundary sliding and stress-induced solution transfer suggest that syntectonic depth for the cataclastic rocks in the d'Abbadie fault zone is between 5-10 km (Fig. 29a; Knipe 1989). Frictional grainboundary sliding is common in cataclasites and evidence of diffusion creep through stress-induced solution transfer in quartz grains suggests temperatures between 200 to $300^{\circ} \mathrm{C}$ (Vernon 2004). Altogether, the best estimate for the average temperature is < $250^{\circ} \mathrm{C}$, at depth between $5-10 \mathrm{~km}$.

The formation of the mylonitic rocks in the Last Peak granite proceeded by ductile flow, on the basis of ductile deformation mechanisms including; dislocation creep, plastic grain-boundary sliding, grain-boundary bulging and strain recovery. Such mechanisms are indicated by subgrains, mica-fish, bulged and serrate grain boundaries, patchy undulose extinction, and ribbons. Brittle deformation mechanisms in the mylonitic rocks include friction, cracking and dislocation glide (frictional grain boundary sliding). These mechanisms mainly affected feldspar, quartz and biotite, and are indicated by antithetic microfaults, microcracks and sutures on grain boundaries. Microcracks and microfaults in K-feldspar porphyroclasts contained in the mylonites are 


\section{D'Abbadie fault zone}

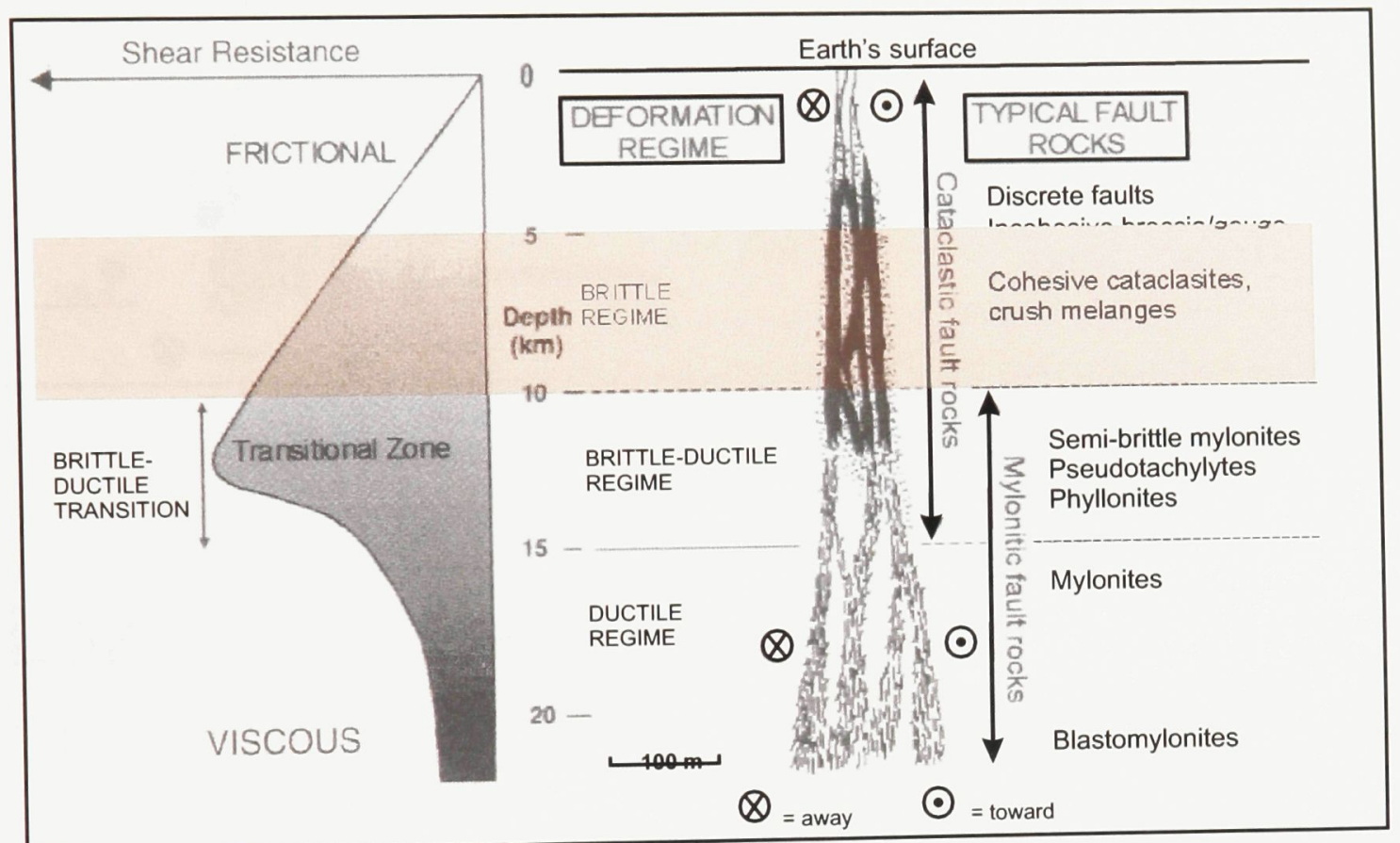

Figure 28. Structures and microstructures observed in the cataclastic fault rocks in the d'Abbadie fault zone placed in the context of a conceptual model for fault zones (modified after Knipe 1989; and Alsop and Holdsworth 2004). The diagrams illustrate the variations in the deformation regime, crustal conditions, and associated fault rocks with respect to depth in the earth's crust for the d'Abbadie fault zone (light brown). 


\section{D’Abbadie fault zone}

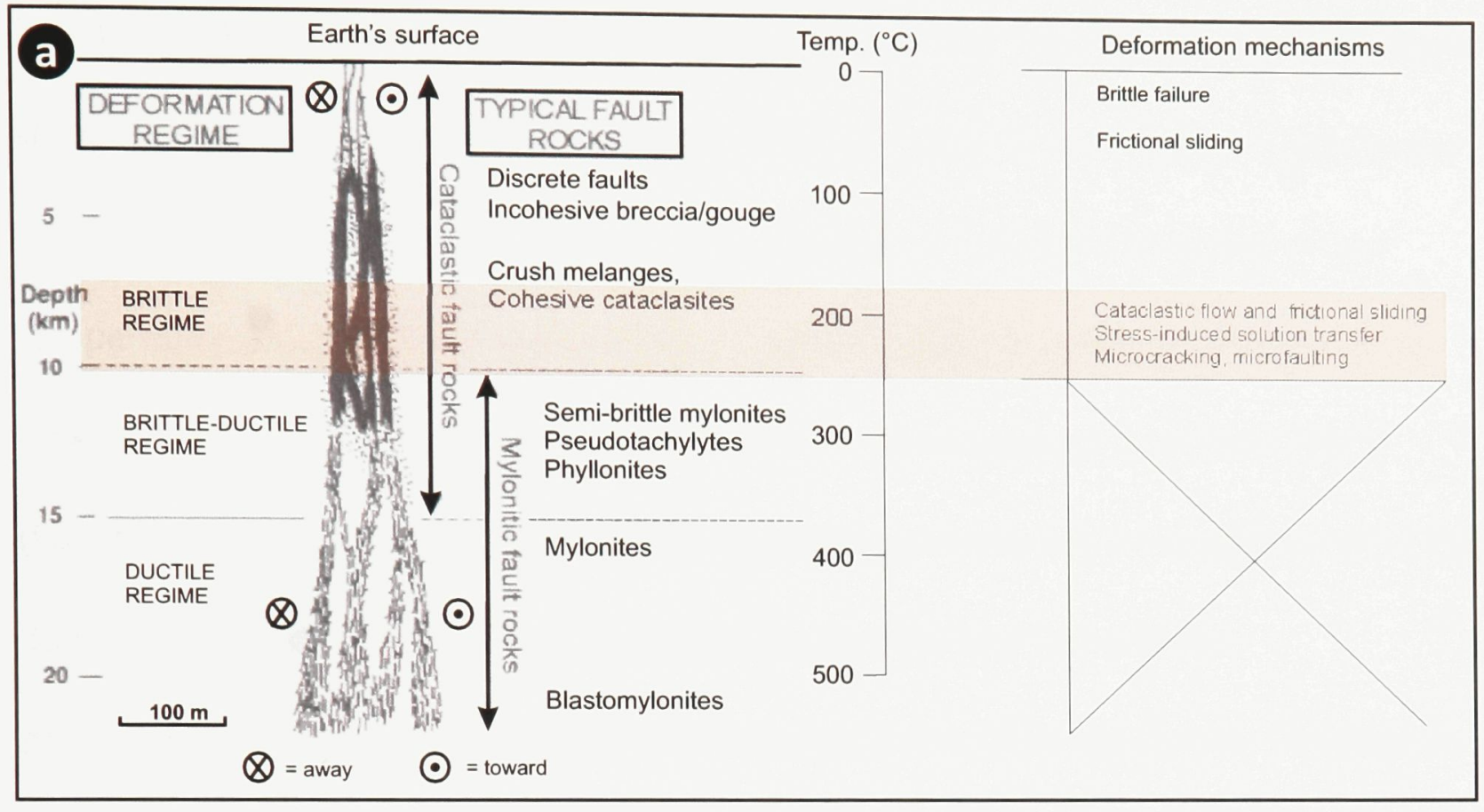

(modified after (a) Knipe 1989; Alsop and Holdsworth 2004)

\section{Last Peak granite}

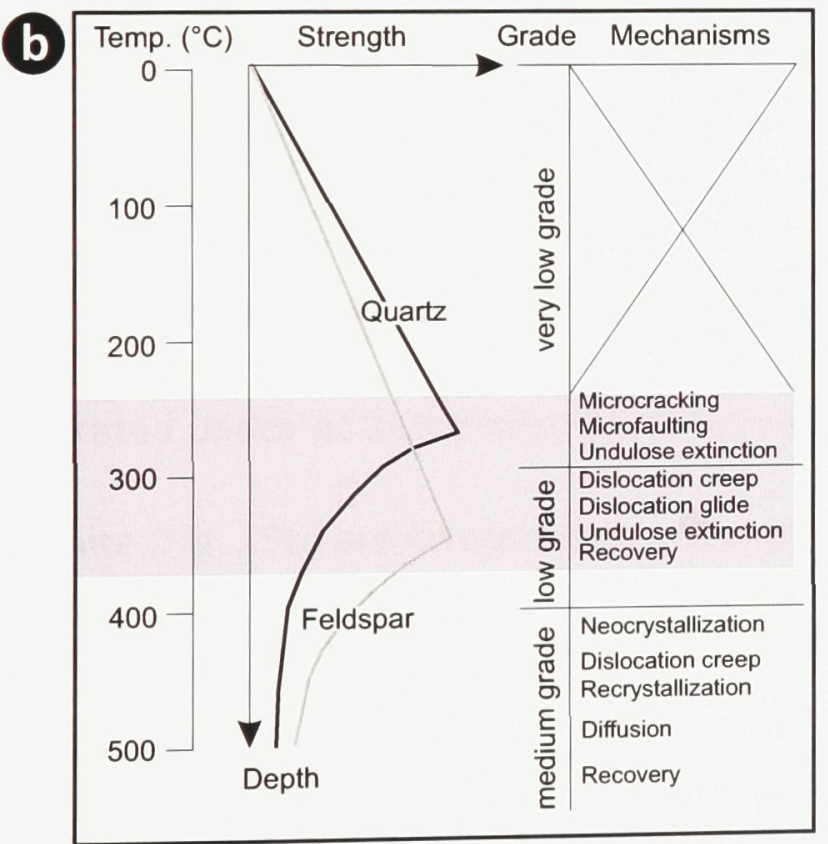

(modified after (b) Passhier and Trouw 1996)
Figure 29. General diagrams showing the potential deformation regime, crustal conditions, and associated fault rocks, deformation mechanisms with respect to depth and temperature conditions in the earth's crust for the a) d'Abbadie fault zone (light brown) (modified after Knipe 1989; Alsop and Holdsworth 2004) and b) deformation mechanisms in with respect to the grade of deformation and the strength of quartz and feldspar with respect to their brittle (straight line) and ductile behavior with increasing temperature (curved line) (Passchier and Trouw 1996) for the Last Peak granite (light pink). 
microstructures that are characteristic of temperature for brittle deformation between 200-400 ${ }^{\circ} \mathrm{C}$ (Passchier and Trouw 1996). Flame perthite in K-feldspar develop when high stresses act on grains and at grain boundaries by processes of exsolution of albite in the crystal (Passchier and Trouw 1996). They typically occur during deformation at low temperature (Passchier and Trouw 1996) - near or above the brittle-ductile transition. Kinking of biotite reflects temperatures for brittle deformation to be at least $250^{\circ} \mathrm{C}$ (Passchier and Trouw 1996). These microstructures generally occur throughout all of the domains of the Last Peak granite, but the flame perthite and fine-grained protomylonites are restricted to the western edge of the Last Peak granite. This may be explained if the granite cooled more quickly at its boundaries compared to its center. Paterson and Tobisch (1992) suggest that small intrusions (e.g. $30 \mathrm{~m}$ to $<20 \mathrm{~km}$ ) at shallow crustal levels can take a few years to $1 \mathrm{Ma}$ to cool. Therefore, the 200-500 m intrusion that was emplaced against cold shallow supracrustal rocks may have cooled relatively quickly.

Based on the microstructures and their associated mechanisms of formation that operated under both the brittle and ductile behaviors, the mylonites in the Last Peak granite (Fig. 29b) are interpreted as low temperature mylonites (or very low to low grade; Passchier and Trouw 1996). This study demonstrates that S-C mylonites in the Last Peak granite formed at low temperatures; at minimum temperatures of $250-350{ }^{\circ} \mathrm{C}$. At very low-grade conditions, feldspar and quartz deform both by brittle and ductile processes (Passchier and Trouw 1996). At low-grade conditions, feldspar still deforms in the brittle regime $\left(300-400^{\circ} \mathrm{C}\right)$, whereas quartz deforms by ductile flow above $250^{\circ} \mathrm{C}$ 
(Passchier and Trouw 1996). One may also suggest that not only the mylonites are of low temperature, but that they have formed at high strain rate.

${ }^{40} \mathrm{Ar} /{ }^{39} \mathrm{Ar}$ dates of ca. 191-195 Ma for the supracrustal rocks of the region, in south-central Yukon, indicate that the region had cooled below $300-350^{\circ} \mathrm{C}$ (Hansen et al. 1991, 1992; unpublished data by M. Colpron 2005), the closure temperature of Ar diffusion in muscovite, a temperature representative of a shallow crust by Early Jurassic and at depth of approximately $12-14 \mathrm{~km}$ based on the average geothermal gradient of $25^{\circ} \mathrm{C} / \mathrm{km}$. Such date, associated temperatures and depths suggest that the d'Abbadie fault zone was active in a cold shallow crust, which is consistent with brittle deformation. This also suggests that brittle deformation and $S_{m y 2}$ in the low temperature mylonites in the Last Peak granite postdates $\mathrm{S}_{\mathrm{t} 2}$ and metamorphism that affected the supracrustal rocks. The presence of low temperature mylonites in the d'Abbadie fault zone is consistent with the low metamorphic grade conditions of the d'Abbadie fault zone and deformation in a shallow brittle crust.

\subsection{Regional significance of the d'Abbadie fault zone transect}

This section aims at understanding and interpreting the orientation of the d'Abbadie fault zone transect with respect to the rest of the d'Abbadie fault length, its significance with the Teslin fault, and the significance of late faults cutting across the d'Abbadie fault zone.

Orientation of the fault transect in contrast with the whole fault length 
The northwestward strike (e.g. azimuth $350^{\circ}$ ) of the d'Abbadie fault zone in the study area is different from its northward strike (e.g. azimuth $000^{\circ}$ ) and map expression mapped by Colpron (2005b) in the Livingstone Creek area (NTS 105E/8, Fig. 5), and suggested by de Keijzer (2000) in the Teraktu Creek area (NTS 105E/9), directly to the north of the study area (Fig. 6). Field evidence shows that the overall faults in the study area are or may be concordant with the northwestward strike of the regional foliation. This can be explained if the fault zone developed along a pre-existing mechanical anisotropy (e.g. $\mathrm{S}_{\mathrm{t} 2}$ ). Depending upon the orientation of pre-existing anisotropies they may localize faults, because they are structures that are already there and therefore easier to reactivate than to form new tectonic features (Thatcher 1995; Holdsworth et al. 1997, 2001). This means that $\mathrm{S}_{\mathrm{t} 2}\left(\mathrm{e} . \mathrm{g}\right.$. azimuth $\left.335-350^{\circ}\right)$ in the Last Peak succession could have provided a preferential orientation to facilitate faulting along its strike to form the d'Abbadie fault zone.

\section{Significance of the d'Abbadie fault zone with respect to the Teslin fault}

The d'Abbadie fault zone, together with the Cassiar and Big Salmon faults, is a first order splay fault that diverges from the primary regional-scale Teslin fault (Figs. 1 and 3; Gabrielse et al. 2006). First order splay faults, as defined by Scholz et al. (2010), are faults that have the same sense of shear, are concurrently active at the time of formation, and are of the same order as the primary fault (length, slip rate, total slip). Mid-Cretaceous dextral strike-slip displacement along the Teslin fault is in part interpreted on the basis of constraints on the Cassiar and d'Abbadie faults which are 
interpreted as first-order splay faults diverging from the Teslin fault. The termination of the d'Abbadie fault with the Teslin fault may not be exposed, but one might predict that it would keep the same strike for another $15 \mathrm{~km}$ length to the south, until it reaches the Teslin fault. That is based on the known north-striking $70 \mathrm{~km}$ length of the d'Abbadie fault, and assumed from the facts that the d'Abbadie fault does not displace or have a fault expression to the southwest of the Teslin fault (Fig. 4). The relationship between the Teslin and d'Abbadie fault is uncertain, but some seismic data is available in the literature (Cook et al. 2004; Snyder et al. 2005). Seismic-reflection surveys in the Canadian Cordillera expressed that the Teslin fault extends to mid-crustal level (Cook et al. 2004; Snyder et al. 2005).

\section{Late faults cutting across the d'Abbadie fault zone}

The significance and timing of the northeast-striking (058/88 SW) faults in sparse locations throughout the fault zone (e.g. Cluster 2; Fig. 21d) is unclear, but they are interpreted as brittle faults that occurred post-d'Abbadie fault zone.

\subsection{Implication for reactivation}

Reactivation is defined as the accommodation of geologically separable displacement events (intervals $>1 \mathrm{Ma}$ ) along pre-existing structures (Holdsworth et al. 1997) or along structures that formed prior to the onset of the current tectonic regime (Muir Wood and Mallard 1992). Several criteria based on stratigraphic, structural, geochronological and neotectonic evidence (Holdsworth et al. 1997) all constitute reliable geological evidence that may be used to recognize the potential for a fault to 
have undergone reactivation. All criteria must show evidence for repetition of displacement and associated deformation based on absolute or relative timing constraints (Holdsworth et al. 1997). Other sources, as cited in Holdsworth et al. (1997), report field evidence including the concordance of structures in younger rocks with those in adjacent basement regions (Hoppin and Palmquist 1965), the orientation of younger structures that do not match the field stress patterns related to causative plate motions (Donath 1962), and concordance of trends in the cover with geological or geophysical lineaments that are of possible deep crustal origin (Sutton and Watson 1986) or related to enigmatic fracture patterns defined on a global scale (Sonder 1965; O'Driscoll 1980). However, according to Holdsworth et al. (1997), these are considered to be equivocal and should be avoided as reactivation criteria unless they are combined with detailed seismic data and taking into account with any potential discontinuities that could be across regional unconformities (Clausen et al. 1994).

With respect to the d'Abbadie fault zone, for reactivation to have occurred, one might predict overprinting relationships, a complex distribution of deformation within the fault zone, a change in the kinematic history of the Last Peak granite (e.g. overprinting structures), and evidence for modern or historical seismicity (e.g. pseudotachylyte). Aside from a locally brittle component overprinting the mylonites (localized cataclasites related to faulting in the d'Abbadie fault zone and interpreted as the progression in the deformation during one event as the rock cooled) field evidence suggests that the d'Abbadie fault zone did not get reactivated and is an organized fault. This is based on the coherent fault rocks, intact and consistent distribution of the 
strands in the d'Abbadie fault zone, and of the intact contact relationships, internal strain gradient, and kinematic history of the Last Peak granite. This suggests that the fault zone has undergone no significant reactivation and may imply that it is a shortlived structure that was strictly active in the mid-Cretaceous. 
SECTION 5 - SUMMARY OF CONCLUSIONS 
In the Cretaceous, intracontinental strike-slip faulting created a system of anastomosing strike-slip faults that truncated the rocks in the Canadian Cordillera (Fig. 1). Cretaceous plutonism was coeval with Cretaceous strike-slip faulting (Gabrielse et al. 2006); an example is the d'Abbadie fault zone with the Last Peak granite. The main conclusions reached in this study regarding the structural history of the d'Abbadie fault zone are:

1. In the study area, the d'Abbadie fault zone truncates polydeformed Paleozoic metasedimentary rocks of the Last Peak succession and Mendocina orthogneiss (Yukon-Tanana terrane), and the Cretaceous Last Peak granite (Fig. 6).

2. The d'Abbadie fault zone is a $2 \mathrm{~km}$-wide brittle dextral strike-slip fault made of multiple anastomosing faults defined by cataclasites, and localized (200-500 mwide) dextral S-C mylonites in the Last Peak granite (Fig. 11).

3. Predominantly inhomogeneous brittle deformation in the form of cataclasic flow and fracturing mostly controlled the formation of the anastomosing brittle faults and shear fractures. Ductile deformation in the form of dislocation creep, plastic grain-boundary sliding, grain-boundary bulging and strain recovery controlled the formation of the S-C mylonites in the ca. 96 Ma Last Peak granite.

4. The d'Abbadie fault zone is a dextral strike-slip fault. This is based on northweststriking and steeply dipping structures and microstructures in mylonitic rocks in the syntectonic Last Peak granite, the relative near horizontal motion on brittle shear fracture planes throughout the fault zone, and the near horizontal plunges of associated lineations.

5. The Last Peak granite is syntectonic with the displacement of the d'Abbadie fault zone based on primary contact relationships, restriction of mylonitic rocks to within the granite (Fig. 26), and the presence of a ductile strain gradient within mylonites of the Last Peak granite, from the Protomylonite domain to the Ultramylonite domain (Fig. 16).

6. The Last Peak granite may be a minor component of the fault zone in terms of volume (Fig. 26), but it is an important component because it constrains the sense and timing of displacement, and part of the magnitude of displacement of the d'Abbadie fault zone. 
7. The minimum differential displacement on the d'Abbadie fault zone is best estimated from the ductile strain in the Last Peak granite, which represents 7.6 $\mathrm{km}$, assuming a thickness of $2.5 \mathrm{~km}$ and angular shear strain of $72^{\circ}$.

8. Part of the brittle deformation along the d'Abbadie fault zone is at least ca. 96 Ma and younger, based on the crystallization age of the syntectonic Last Peak granite and brittle cataclasites cutting across the shear foliation in the granite.

9. The crystallization age of the ca. $96 \mathrm{Ma}$ Last Peak granite, deformation ages of the region and low temperature mylonites are all consistent with granite that cooled quickly, shortly after it intruded. The brittle faulting history associated with the displacement of the d'Abbadie fault zone is restricted to the midCretaceous, based on the intact granitic sheet, contact relationships and internal strain gradient in the Last Peak granite, indicating that the fault has not undergone significant reactivation. 
SECTION 6 - FUTURE RECOMMENDATIONS 
Here is a list of recommendations of future work to be carried out in the area of the d'Abbadie fault zone:

- Mapping to the south of the Boswell Mountain (Fig. 4) would be interesting in the hope to find the fault termination of the d'Abbadie fault with the Teslin fault. This could be useful to further constrain the relationship between the Teslin and the d'Abbadie fault.

- Looking for potential piercing points along the rest of the length of the fault zone, such as folds in a distinctive layer or corresponding lithologies on either side of the fault. Doing so would help determining the displacement vector (magnitude of displacement) of the d'Abbadie fault zone and ultimately constrain the magnitude of displacement along the strike-slip Cretaceous fault system in the Canadian Cordillera.

- Conducting detailed structural mapping of the Mendocina orthogneiss. This could improve knowledge of the deformation history of the Yukon-Tanana terrane, an history that pre-dates the d'Abbadie fault zone; expend the knowledge of reactivation; and constrain the complex folding history of the mylonites. Perhaps, one may want to determine to what generation the folds belong to and if they correlate with the fold generations in the supracrustal rocks.

- Unraveling the absolute exhumation history of the d'Abbadie fault zone by conducting a detailed thermochronology study. This would be useful to further 
constrain the structural history of the d'Abbadie fault zone, especially the history post-96 Ma.

- Sampling for ${ }^{40} \mathrm{Ar} /{ }^{39} \mathrm{Ar}$ thermochronology studies maybe done very carefully. As shown in Appendix, data from ${ }^{40} \mathrm{Ar} /{ }^{39} \mathrm{Ar}$ thermochronology on muscovite around the d'Abbadie fault zone is too poor to reliably be interpreted. Muscovite grains that seem clear and undisturbed may be full of impurities. The best thing to do if one wants to conduct such study would be to probe the crystals first to make sure they don't have impurities that would affect their chemical composition and are not altered. 
REFERENCES 
Alsop, G.I., and Holdsworth, R.E. 2004. Shear zones - an introduction and overview. In Flow Processes in Faults and Shear Zones, G. I., Alsop, R. E. Holdsworth, K. J., W., McCaffrey, and M., Hand, (eds.) 2004. Geological Society, London, Special Publications, 224, p. 1-9.

Baadsgaard, H., Folinsbee, R.E., and Lipson, J. 1961. Caledonian or Acadian granites of the northern Yukon Territory, Geology of the Arctic, G.O. Raasch (ed.), University of Toronto Press, p. 458-465.

Bell, T.H., and Etheridge, M.A. 1973. Microstructure of mylonites and their descriptive terminology. Lithos 6, p. 337-348.

Berman, R.G., Ryan, J.J., Gordey, S.P., and Villeneuve, M. 2007. Permian to Cretaceous polymetamorphic evolution of the Stewart River region, Yukon-Tanana terrane, Yukon, Canada: P-T evolution linked with in situ SHRIMP monazite geochronology. Metamorphic Geology, vol. 25, p. 803-827.

Bostock, H.S., and Lees, E.J. 1938. Laberge map-area, Yukon. Geological Survey of Canada, Geological map (105E), 1: 253440 scale, and report, 33 p.

Clausen, O.-R., Korstgard, J.A., Petersen, K., McCann, T., O’Reilly, B.M., Shannon, P.M., Howard, C.B., Mason, P.J., Walsh, J.J., and Watterson, J. 1994. Systematics of faults and fault arrays. In Modelling the Earth for Oil Exploration, HELBIG, K. (ed.). Final Report of the CEC's Geoscience Program 1990-1993. Elsevier, Oxford, p. 205-306.

Colpron, M. 2005a. Preliminary investigation of the bedrock geology of the Livingstone Creek area (NTS 105E/8), south-central Yukon. In Yukon Exploration and Geology 2004, D.S. Emond, L.L. Lewis, and G.D. Bradshaw (eds.), Yukon Geological Survey, p. 95-107.

Colpron, M. 2005b. Geological map of Livingstone Creek area (NTS 105E/8), Yukon (1: 50 000 scale), Yukon Geological Survey, Open File 2005-9.

Colpron, M. 2006a. Tectonic assemblage map of Yukon-Tanana and related terranes in Yukon and northern British Columbia (1:1 000000 scale). Yukon Geological Survey, Open File 2006-1.

Colpron, M. 2006b. Geology and mineral potential of Yukon-Tanana terrane in the Livingstone Creek area (NTS 105E/8), south-central Yukon. In Yukon Exploration and Geology 2005, D. S. Emond, G. Bradshaw, L. L. Lewis, and L. H. Weston (eds.), Yukon Geological Survey, p. 93-107. 
Colpron, M., 2011. Geological compilation of Whitehorse trough - Whitehorse (105D), Lake Laberge (105E), and part of Carmacks (115I), Glenlyon (105L), Aishihik Lake (115H), Quiet Lake (105F) and Teslin (105C). Yukon Geological Survey, Geoscience Map 2011-1, 1:250,000.

Colpron, M., Nelson, J., and Murphy, D.C. 2006a. A tectonostratigraphic framework for the pericratonic terranes of the northern Cordillera. In Paleozoic Evolution and Metallogeny of Pericratonic Terranes at the Ancient Pacific Margin of North America, Canadian and Alaskan Cordillera, M. Colpron and J.L. Nelson (eds.), Geological Association of Canada, Special Paper 45, p. 1-23.

Colpron, M., Mortensen, J.K., Gehrels, G.E., and Villeneuve, M.E. 2006b. Basement complex, Carboniferous magmatic arcs and Paleozoic deformation in YukonTanana Terrane of central Yukon; In Paleozoic Evolution and Metallogeny of Pericratonic Terranes at the Ancient Pacific Margin of North America, Canadian and Alaskan Cordillera. Geological Association of Canada Special Paper, Edited by M. Colpron and J.L. Nelson, Geological Association of Canada Special Paper 45, pp. 131-152.

Colpron, M., Nelson, J., and Murphy, D. 2007. Northern Cordilleran terranes and their interactions through time. Geological Society of America Today, vol. 17, p. 4-10.

Cook, F.A., Clowes, R.M., Snyder, D.B., van der Velden, R.J., Hull, K.W., Erdmer, P., and Evenchick, C.E. 2004. Precambrian crust beneath the Mesozoic northern Canadian Cordillera discovered by Lithoprobe seismic reflection profiling. Tectonics, vol. 23, TC2010, 10.1029/2002TC001412.

de Keijzer, M., Williams, P.F., and Brown, R.L. 1999. Kilometre-scale folding in the Teslin zone, northern Canadian Cordillera, and its tectonic implications for the accretion of the Yukon-Tanana terrane to North America. Canadian Journal of Earth Sciences, vol. 39, p. 479-494.

de Keijzer, M. 2000. Tectonic evolution of the Teslin zone and the Cassiar terrane, northern Canadian Cordillera. Unpublished Ph.D. thesis, University of New Brunswick, Fredericton, New Brunswick, 391 p.

de Keijzer, M., Mihalynuk, M.G., and Johnston, S.T. 2000. Structural investigation of an exposure of the Teslin fault. In Current Research, Part A, Geological Survey of Canada, Paper 2000-A.

Donath, F.A. 1962. Analysis of Basin and Range structure, south-central Oregon. Bulletin of the Geological Society of America, 73, p. 1-16. 
Gabrielse, H. 1985. Major dextral transcurrent displacements along the Northern Rocky Mountain Trench and related lineaments in north-central British Columbia. Geological Society of America, Bulletin 96: 1-14.

Gabrielse, H., Murphy, D.C., and Mortensen, J.K. 2006. Cretaceous and Cenozoic orogenparallel displacement, magmatism and paleogeography, north-central Canadian Cordillera, in Haggart, J.W., Monger, J.W. and Enkin, R.J. (eds), Paleogeography of the North American Cordillera: Evidence for and against large-scale displacements, Geological Association of Canada, Special Paper 46, p. 255-276.

Gallagher, C.S. 1999. Regional-scale transposition and late large-scale folding in the Teslin zone, Pelly Mountains, Yukon. Unpublished M.Sc. thesis, Carleton University, Ottawa, Ontario, 199 p.

Hansen, V.L. 1989. Structural and kinematic evolution of the Teslin suture zone, Yukon: Record of an ancient transpressional margin, Journal of Structural Geology, vol. 11, p. 717-733.

Hansen, V.L. 1992. P-T evolution of the Teslin suture zone and Cassiar tectonites, Yukon, Canada: evidence for A- and B-type subduction, Journal of Metamorphic Geology, 10, p. 239-263.

Hansen, V.L., Mortensen, J.K., and Armstrong, R.L. 1989. U-Pb, Rb-Sr and K-Ar isotopic constraints for ductile deformation and related metamorphism in the Teslin suture zone, Yukon-Tanana terrane, south-central Yukon. Canadian Journal of Earth Sciences, vol. 26, p. 2224-2235.

Hansen, V.L., Hiezler, T.M., and Harrison, T.M. 1991. Mesozoic thermal evolution of the Yukon-Tanana composite terrane: New evidence from ${ }^{40} \mathrm{Ar}-{ }^{39} \mathrm{Ar}$ data, Tectonics, vol. 10, p. 51-76.

Harvey, J.L., Brown, R.L., and Carr, S.D. 1996. Progress in structural mapping in the Teslin suture zone, Big Salmon Range, central Yukon, LITHOPROBE Report no. 45 (1996 SNORCLE Transect meeting), p. 33-43.

Harvey, J.L., Carr, S.D., Brown, R.L., and Gallagher, C. 1997. Deformation history and geochronology of plutonic rocks near the d'Abbadie fault, Big Salmon Range, Yukon, LITHOPROBE Report no. 56 (1997 SNORCLE Transect meeting), p. 103114.

Holdsworth, R.E., Butler, C.A., and Roberts, A.M. 1997. The recognition of reactivation during continental deformation. Journal of the Geological Society, 154, p. 73-78. 
Holdsworth, R.E., Stewart, M., Imber, J., and Strachan, R.A. 2001. The structure and rheological evolution of reactivated continental fault zones. A review and case study. In Continental reactivation and reworking, Miller, J.A., Holdsworth, R.E., Buick, I.S., and Hand, M. (eds.), Geological Society, London, Special Publications, 184, p. $115-137$.

Hoppin, R.A., and Palmquist, J.C. 1965. Basement influence on later deformation: the problem, techniques of investigation and examples from the Bighorn Mountains, Wyoming. Bulletin of the American Association of Petroleum Geologists, 49, p. 993-1003.

Kim, Y.-S., Peacock, D.C.P., and Sanderson, D.J. 2004. Fault damage zones, Journal of Structural Geology, 26, p. 503-517.

Kretz, R. 1983. Symbols for rock forming minerals. American Mineralogist, 68, p. 277279.

Lister, G.S., and Snoke,A.W. 1984. S-C Mylonites. Journal of Structural Geology, vol. 6, p. 617-638.

Lowdon, J.A. 1961. Age determinations by the Geological Survey of Canada, Report 2, Isotopic ages, Geological Survey of Canada, Paper 61-17, 127 p.

Molnar, P. 1988. Continental tectonics in the aftermath of plate tectonics. In Nature, 335, p. 131-137.

Mortensen, J.K. 1992. Pre-mid-Mesozoic tectonic evolution of the Yukon-Tanana terrane, Yukon and Alaska. Tectonics, vol. 11, p. 836-853.

Mortensen, J.K., Sluggett, C. Liverton, T., and Roots, C.F. 2006. U-Pb zircon and monazite ages for the Seagull and Cassiar batholiths, Wolf Lake map area, southern Yukon, Yukon Exploration and Geology, 2005, Emond, D.S., Bradshaw, G.D., Lewis, L.L. and Weston, L.H (eds.), Yukon Geological Survey, p. 257-266.

Muir Wood, R. and Mallard, D.J. 1992. When is a fault 'extinct'? Journal of the Geological Society, London, 149, p. 251-256.

Nelson, J., Colpron, M., Piercey, S.L., Dusel-Bacon, C., Simard, R.L. and Roots, C.F., 2006. Paleozoic tectonic and metallogenetic evolution of pericratonic terranes in Yukon, northern British-Columbia and eastern Alaska. In Paleozoic evolution and Metallogeny of Pericratonic Terranes at the Ancient Pacific Margin of North 
America, Canadian and Alaskan Cordillera, M. Colpron and J.L. Nelson (eds.), Geological Association of Canada, Special Paper 45, p. 323-360.

O'Driscoll, E.S.T. 1980. The double helix in global tectonics. Tectonophysics, 63, p. 397417.

Passchier, C.W., and Simpson, C. 1986. Porphyroclasts systems as kinematic indicators, Journal of structural geology, vol 8, no 8, p. 831 to 843.

Passchier, C.W., and Trouw, R.A.J. 1996. Microtectonics, by C.W. Passchier and R.A.J. Trouw. Springer-Verlag, Berlin 1996. 289 p.

Paterson, S.R., and Tobisch, O.T. 1992. Rates of processes in magmatic arcs: implications for the timing and nature of pluton emplacement and wall rock deformation, Journal of Structural Geology, Vol. 14, No. 3, p. 291-300.

Ramsay, J.G., and Graham, R.H. 1970. Strain variation in shear belts. Canadian Journal of Earth Sciences, 7, p. 786-813.

Ramsay, J.G., and Hubert, M.I. 1983. The techniques of modern structural geology, 1: Strain analysis. Academic press, London.

Schmid, and Handy 1991. Towards a genetic classification of fault rocks: geological uses and tectonophysical implications. In Controversies in modern geology, D.W. Müller (ed.), Academic Press, London, p. 339-361.

Scholz, C.H. et al. 2010. The mechanics of first order splay faulting: The strike-slip case. Journal of Structural Geology, 32, p. 118-126.

Sibson, R.H. 1977b. Fault rocks and mechanisms, Journal of geology society of London, vol 133, p. 190-213.

Simpson, C. 1985. Deformation of granitic rocks across the brittle-ductile transition. Journal of Structural Geology, vol. 7, p. 503-511.

Snyder, D.B., Roberts, B.J., and Gordey, S.P. 2005. Contrasting seismic characteristics of three major faults in northwestern Canada. Canadian Journal of Earth Sciences, vol. 42 , p. 1223-1237.

Sonder, R.A 1956. Mechanik der Erde. E. Schweizerbart'sche Verlagsbuchhandlung, Stuttgart, Germany. 
Spear, F.S. 1993. Metamorphic phase equilibria and pressure-temperature-time paths. Mineral Society of America, Monograph 1, MSA, Washington, D.C.

Stewart, M., Strachan R.A., and Holdsworth, R.E. 1999. Structure an early kinematic history of the Great Glen Fault Zone, Scotland. Tectonics, 18, p. 326-342.

Struik, L.C. 1993. Intersecting intracontinentai Tertiary transform fault systems in the North American Cordillera. Canadian Journal of Earth Sciences, 30, p. 12621274.

Sutton, J., and Watson, J.V. 1986. Architecture of the continental lithosphere. Philosophical Transactions of the Royal Society, London, A317, p. 5-12.

Thatcher, W. 1995. Microplate versus continuum descriptions of active tectonic deformation. Journal of Geophysical Research, 100, p. 3885-3894.

Tempelman-Kluit, D. 1979. Transported cataclasite, ophiolite and granodiorite in Yukon: Evidence of arc-continent collision, Geological Survey of Canada, Paper 79-14, 27 p.

Tempelman-Kluit, D. 1984. Geology, Laberge (105E) and Carmaks (105I), Yukon Territory, Geological Survey of Canada, Open File 1101, 1:250 000 scale.

Tuttle, O.F., and Bowen, N.L. 1958. Origin of granite in the light of experimental studies in the system NaAlSi3O8-KAISi3O8-SiO2-H2O, Geological Society of America, Mem. 74.

Twiss, R.J., and Moores, E.M. 2007. Structural geology, New York, Freeman, 533 p.

Waldron, J.W.F. 2010. Structural Geology and Tectonics EAS 421/521 course notes, University of Alberta, 2008-2010.

Westberg, E., 2009. Geological map of the 'Mendocina Creek' area (parts of NTS 105E/8 and 105F/5) (1:50,000 scale): Yukon Geological Survey, Open File 2009-44.

Westberg, E., Colpron, M., and Gibson, H. D. 2009. Bedrock geology of western 'Mendocina Creek' (NTS 105F/5) and eastern Livingstone Creek (NTS 105E/8) areas, south-central Yukon, in Weston, L. H., Blackburn, L. R. and Lewis, L. L., (eds.), Yukon Exploration and Geology 2008: Yukon Geological Survey, p. 227239. 
Westerg, E. 2010. The tectonometamorphic and structural evolution of the Yukon-Tanana and Cassiar terranes in the Mendocina Creek area: implications for the tectonic framework of south-central Yukon. Unpublished M.Sc. thesis, Simon Fraser University, BritishColumbia, $157 \mathrm{p}$. 
APPENDIX 


\section{APPENDIX $-{ }^{40} \mathrm{AR} /{ }^{39} \mathrm{AR}$ THERMOCHRONOLOGY}

A.1 Objectives and purposes

${ }^{40} \mathrm{Ar} /{ }^{39} \mathrm{Ar}$ studies may be conducted to determine thermochronological histories

of an area. A selection of samples carrying micas (muscovite or biotite) collected in the d'Abbadie fault zone were analyzed in order to try to constrain the cooling history of the d'Abbadie fault zone, the Last Peak granite and Mendocina orthogneiss. Other ideas were to determine how fast the Last Peak granite cooled, especially if it cooled quickly; to compare the cooling ages of the Last Peak granite with that of the Mendocina orthogneiss; to determine if there is any variation in the cooling ages throughout the fault zone corridor (monotonic or non-monotonic cooling history); and to compare the cooling history of the d'Abbadie fault zone with that of adjacent rocks outside of the fault zone.

The muscovite and biotite (in 09MM197A only) picked for analyses seemed to be clear and undisturbed - required quality of the micas to potentially obtain pertinent results. This Appendix serves as reference to the work that has been done, presents the methodology used (see Section A.2), the data tables (see Section A.3) and the age plots (see Section A.4) for the four analyzed samples including: 09MM040C (Map unit C; Fig.

4; Table I), 09MM070A (Last Peak granite; Table II), 09MM089A (Mendocina orthogneiss; Table III), and 09MM197A (Map unit I; Fig. 4; Table IV). Unfortunately the analysis and results are not relevant to this study. The data shows that the samples have variable chemical composition (see the $\mathrm{Ca} / \mathrm{K}$ diagram above the ${ }^{40} \mathrm{Ar} /{ }^{39} \mathrm{Ar}$ age spectra (A) for the four samples in Section A.4). For example, the composition obtained throughout 
the analyses for sample $09 \mathrm{MM} 040 \mathrm{C}$, is expressed by steps that vary from 0.002 to 0.014 $\mathrm{Ca} / \mathrm{K}$. This variation in the chemical composition of the crystals is due to impurities contained within the crystals. Therefore, data is too poor to reliably be interpreted.

\section{A.2 Methodology}

Several samples were collected over the mapping field season in the summer 2009 whenever micas (muscovite or biotite) were present in a rock for at least $5 \%$ of the mineral modal distribution, and coarse enough to see with the naked eye (over 1 $\mathrm{mm}$ in size) to conduct a ${ }^{40} \mathrm{Ar} /{ }^{39} \mathrm{Ar}$ thermochronological study. Samples were then cut into thin sections to evaluate the dating potential of these micas by means of a petrological study. Selected micas had to be alteration-free, and free of any metamorphic mineral inclusions. A total of four samples were retained for the analysis. The samples fall along a transect across the fault zone.

The samples were prepared following a standard separation technique (Harrison and McDougall, 1999). The samples were crushed using a ceramic mortar and pistol and filtered using USA Standard 500 and 150 microns test sieves. For each sample, 30 mica grains were handpicked. Mineral separates were then packed in thin foil tubes, and were sent for their irradiation at McMaster University in Hamilton, Ontario. The samples were irradiated at 60 megawatt hours for 24 hours in position $5 C$. These samples were later analyzed via laser step-heating at the Geochronology lab of the Geological Survey of Canada in Ottawa by Nancy Joyce and Ellie Knight. The samples were loaded into 1.5 $\mathrm{mm}$ diameter holes of a copper planchet. The samples were heated with a Merchantek 
MIR 10, 10 watts $\mathrm{CO}_{2}$ laser. Argon gas is cleaned in getters for 4 minutes. The gas is analysed using a new instrument called a Noblesse mass spectrometer. Base lines are measured for every analysis, and blank measurements are taken between each sample. Blank values ranges from ${ }^{40} \mathrm{Ar}=6.9 * 10^{-9}$ to $1.2 * 10^{-8} \mathrm{nmol} ;{ }^{39} \mathrm{Ar}=4.9 * 10^{-12}$ to $3.9 * 10^{-11}$ $\mathrm{nmol} ;{ }^{38} \mathrm{Ar}=1.5^{*} 10^{-11}$ to $2.9 * 10^{-11} \mathrm{nmol}$ (see Tables I, II, III and IV below for details). 


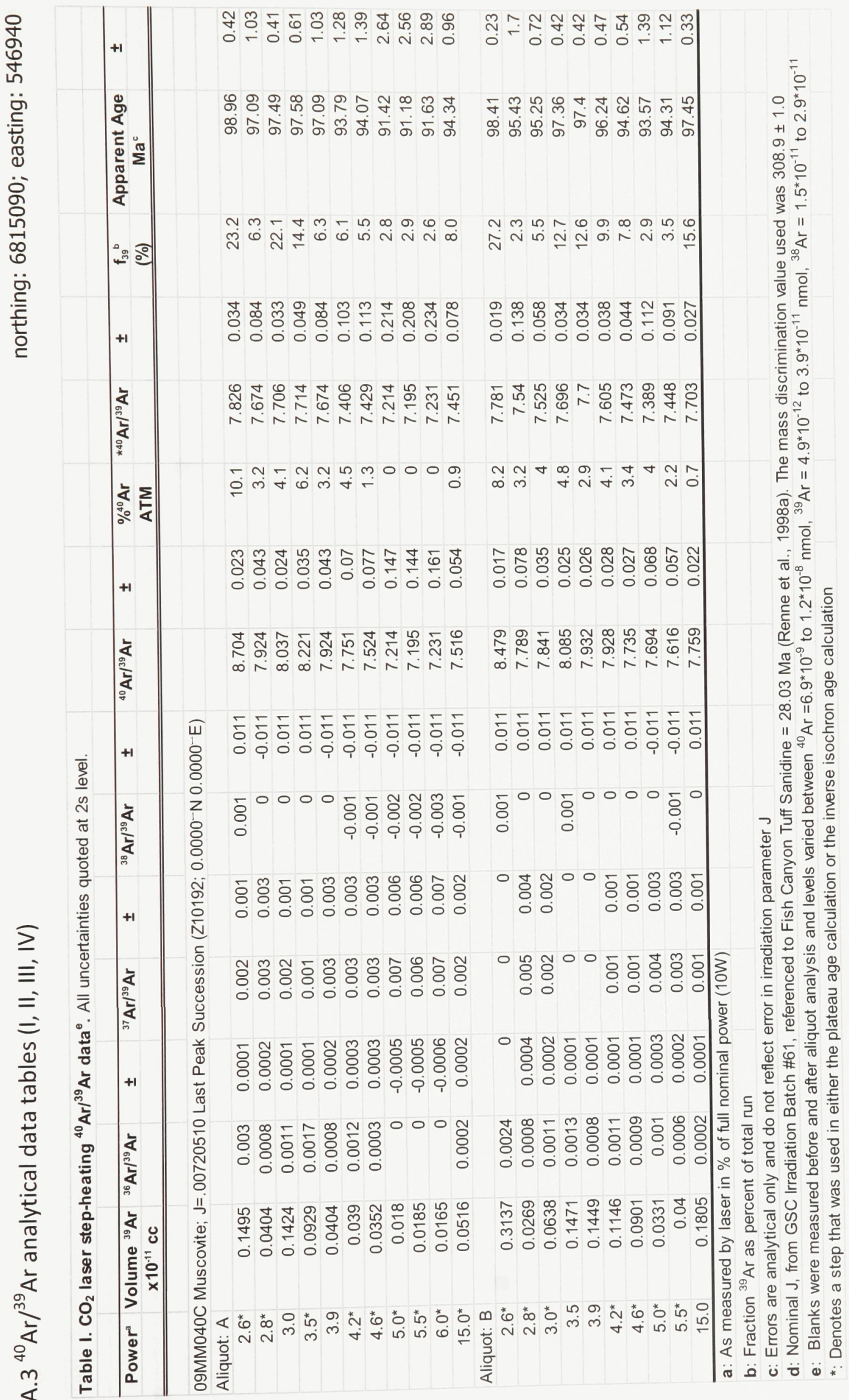




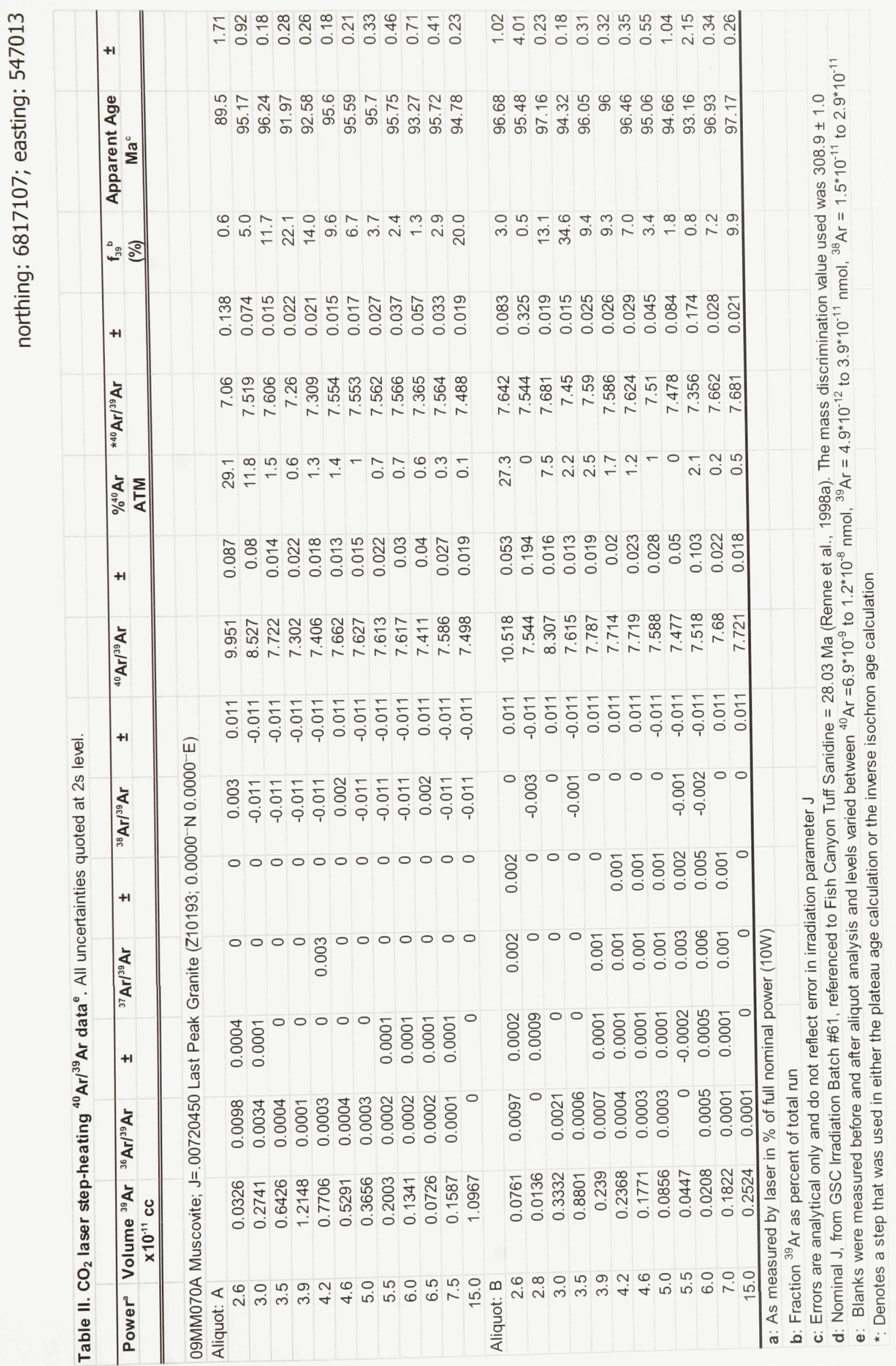




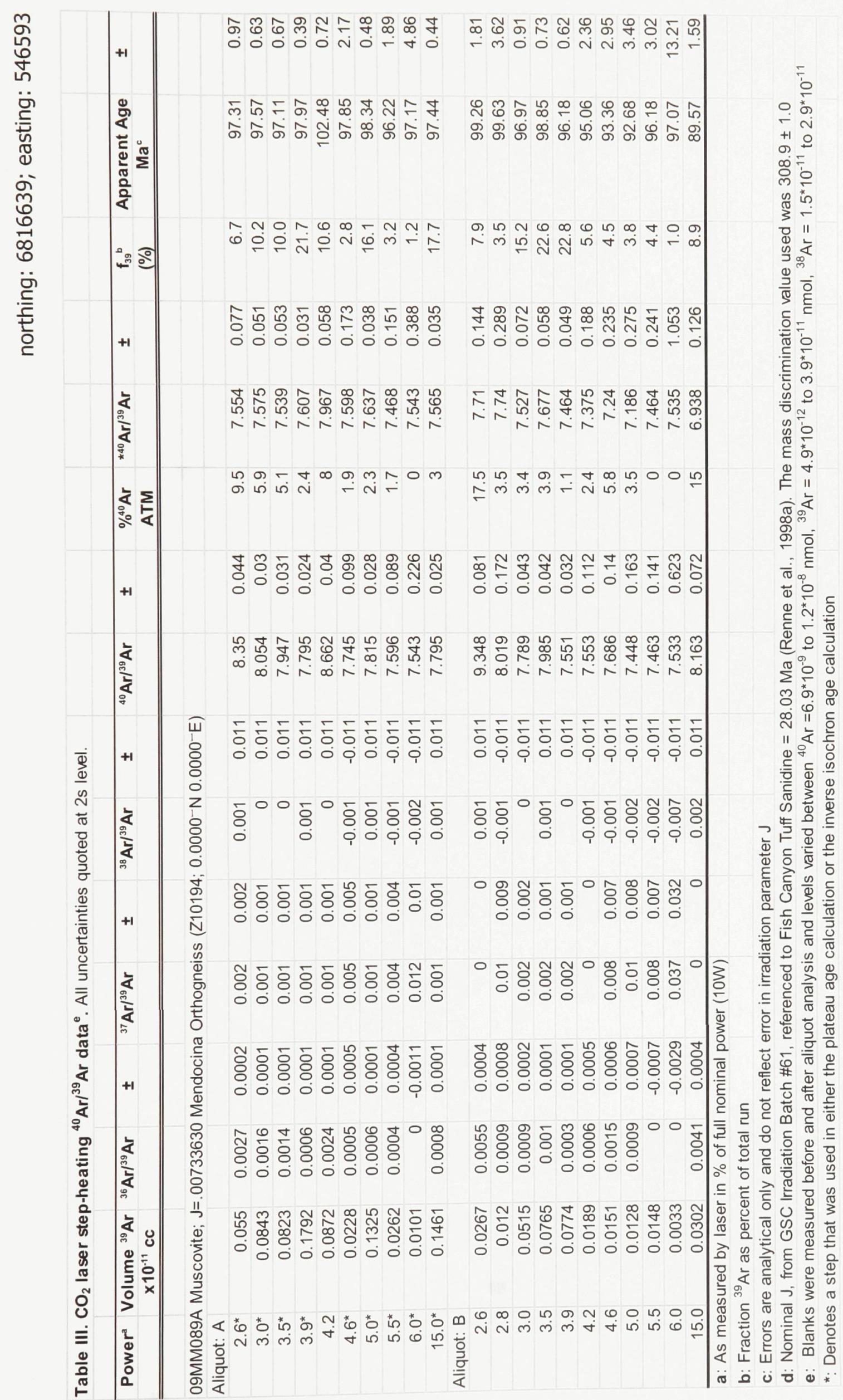




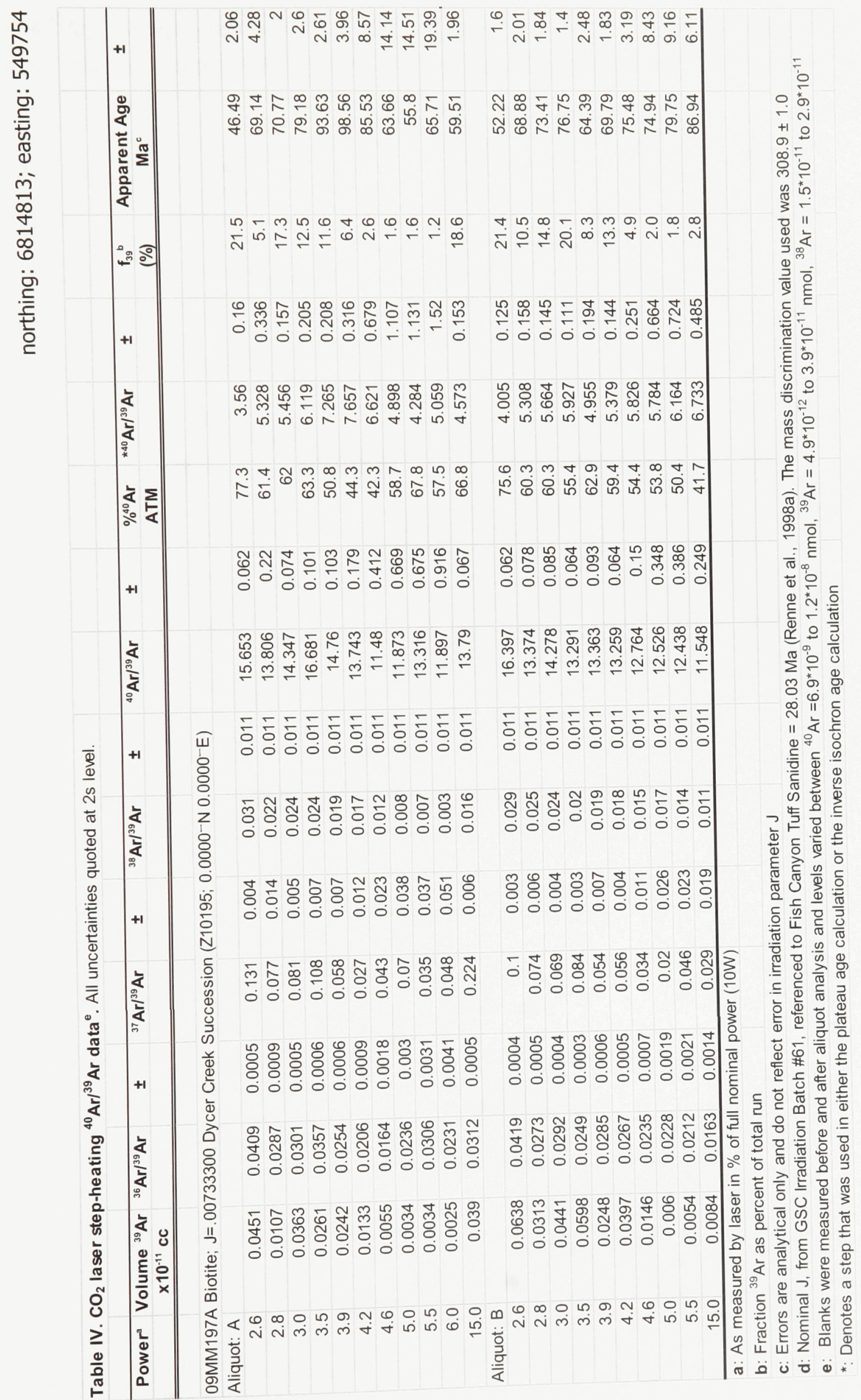


A. $4{ }^{40} \mathrm{Ar} /{ }^{39} \mathrm{Ar}$ age spectra (A) and inverse isochron plot (B) for 2 aliquots (e.g. white and grey side) for samples 09MM040C, 09MM070A, 09MM089A, and 09MM197A.

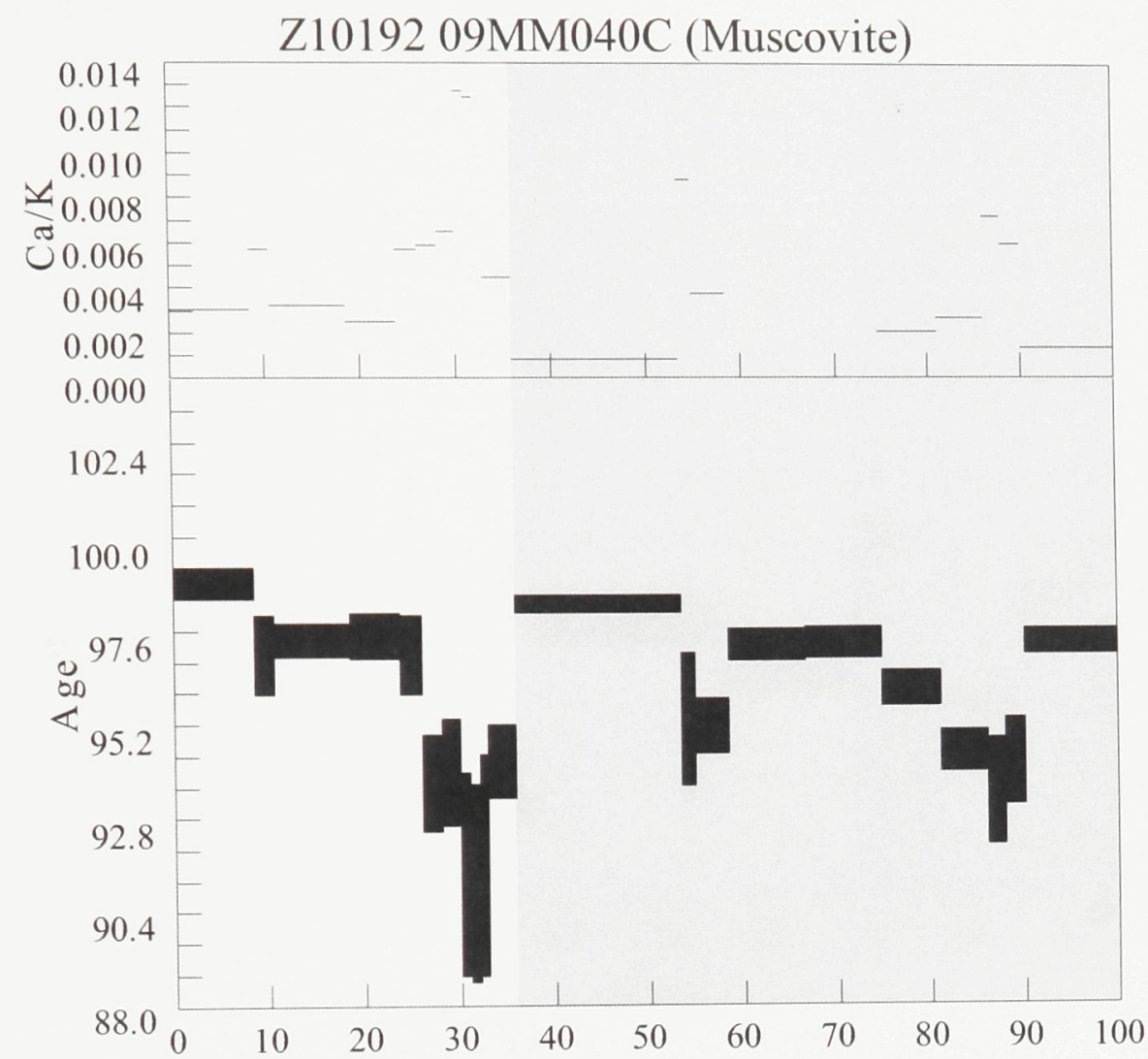

A)

$\% 39 \mathrm{Ar}$

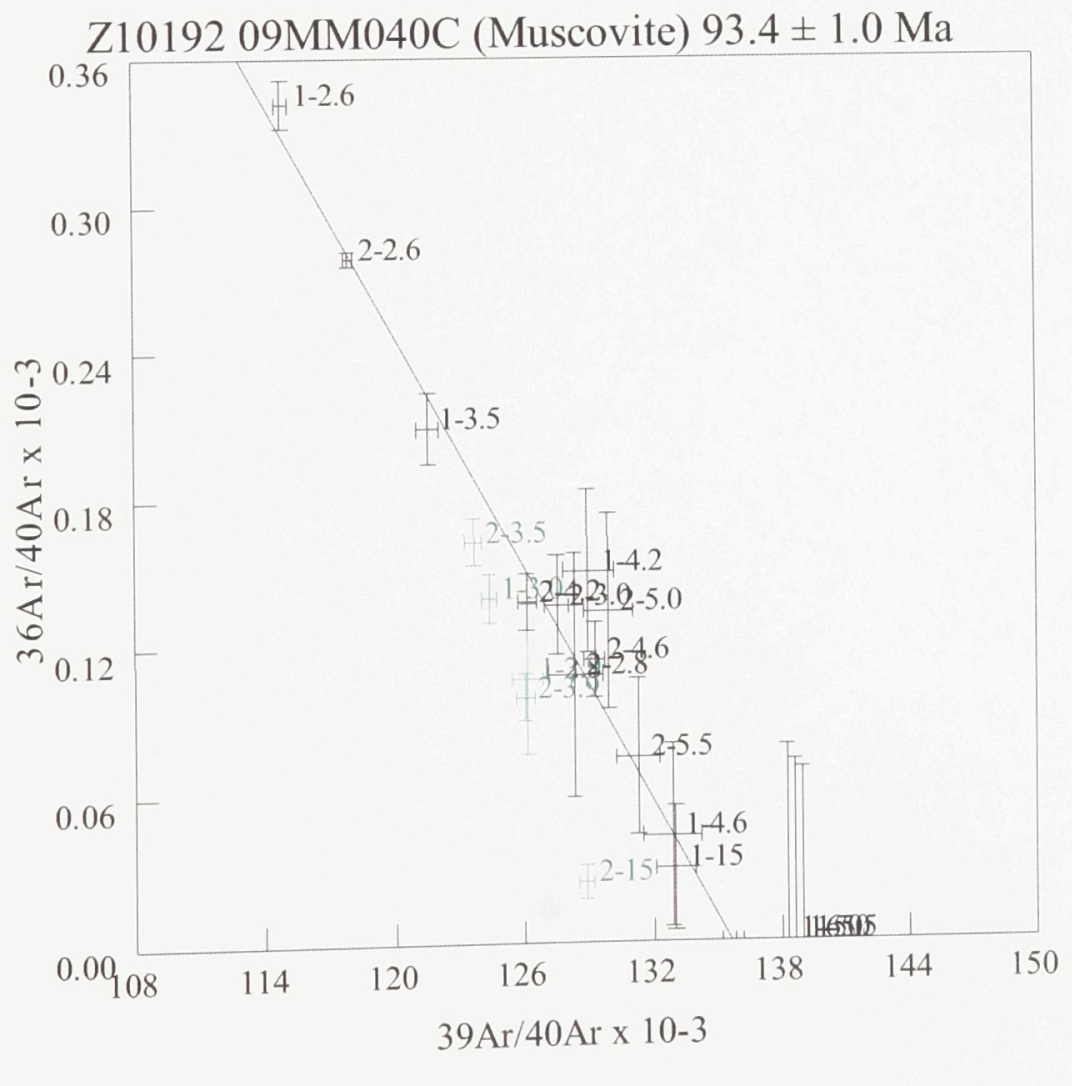




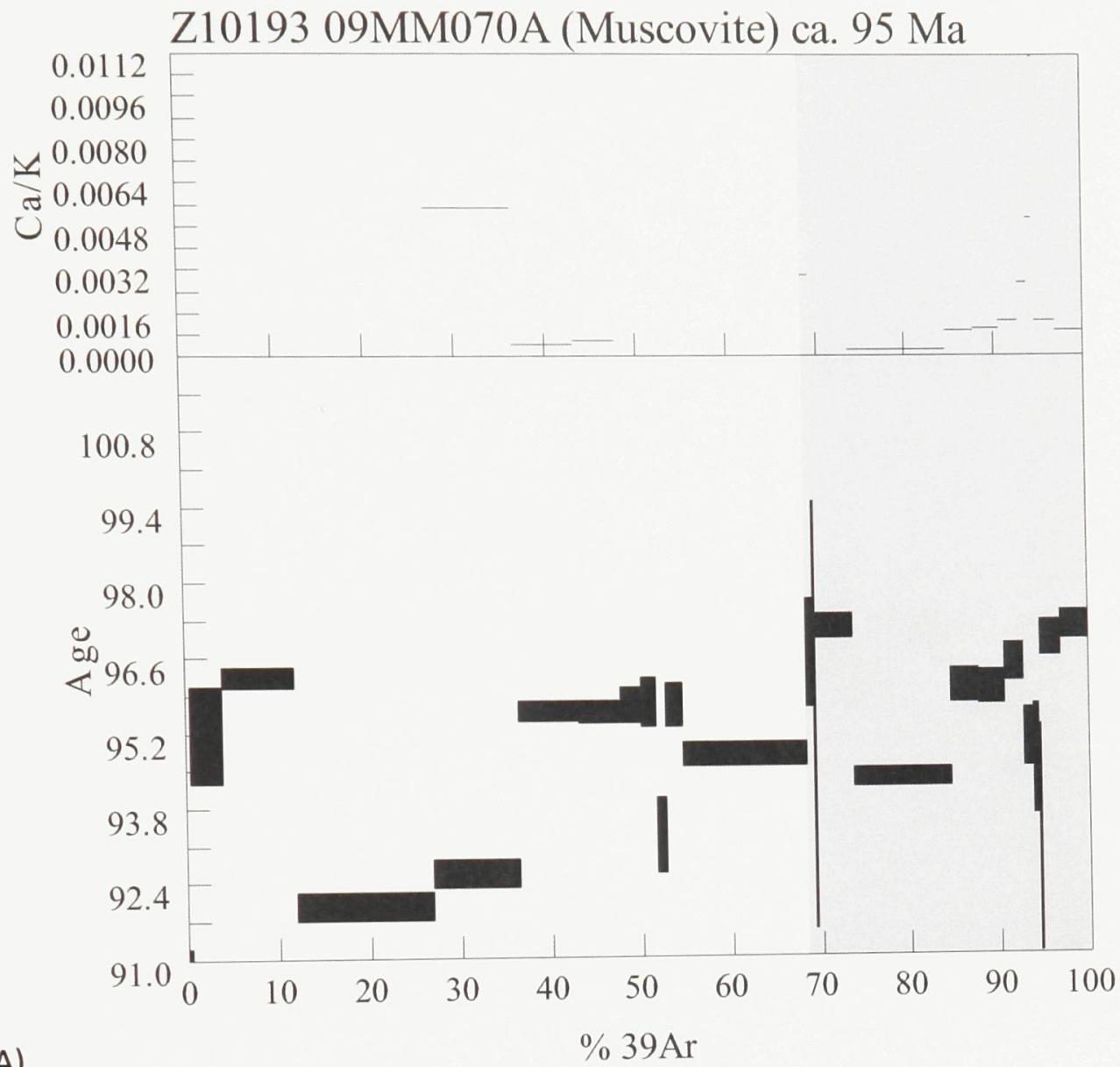

A)

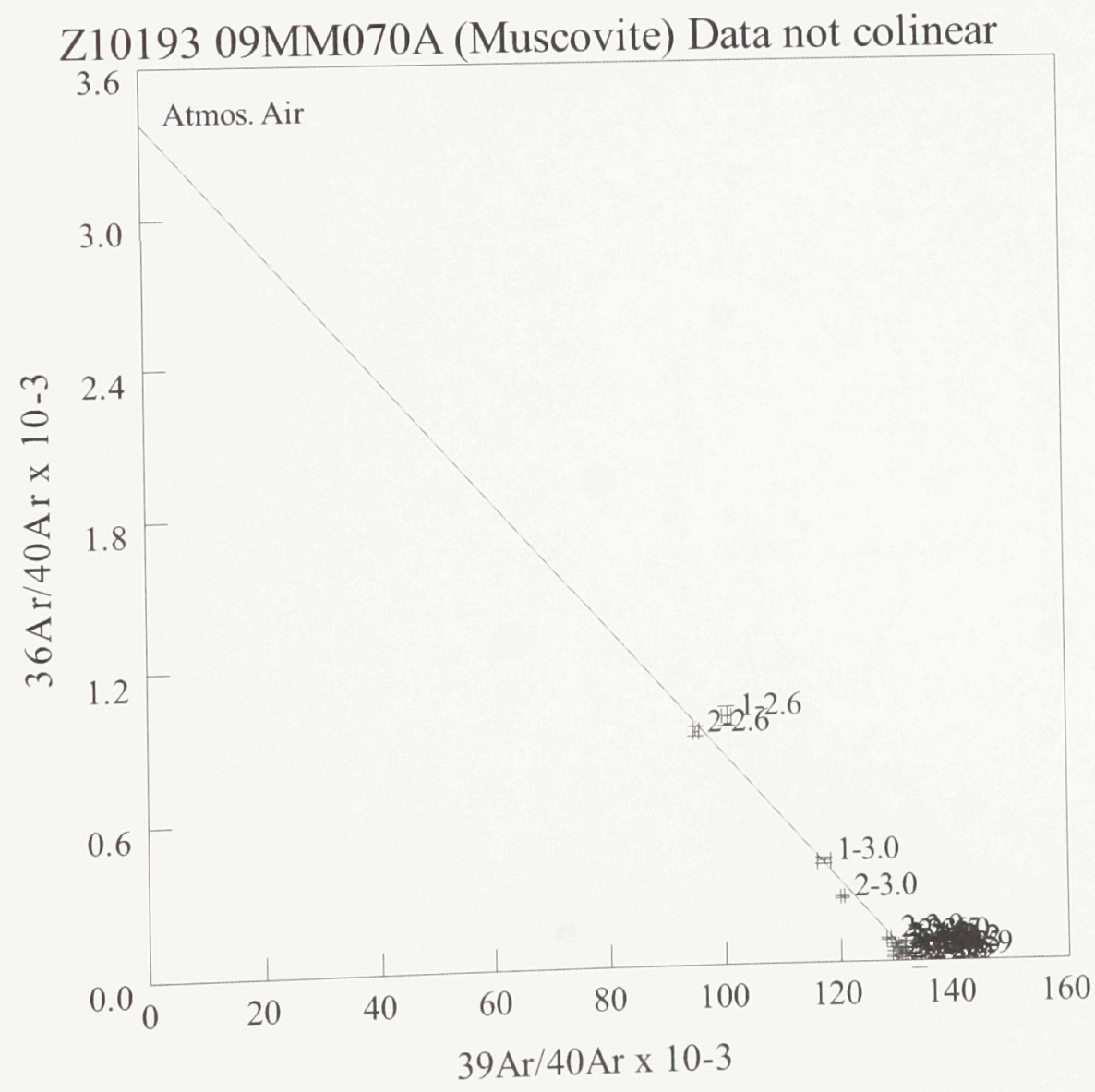

B) 


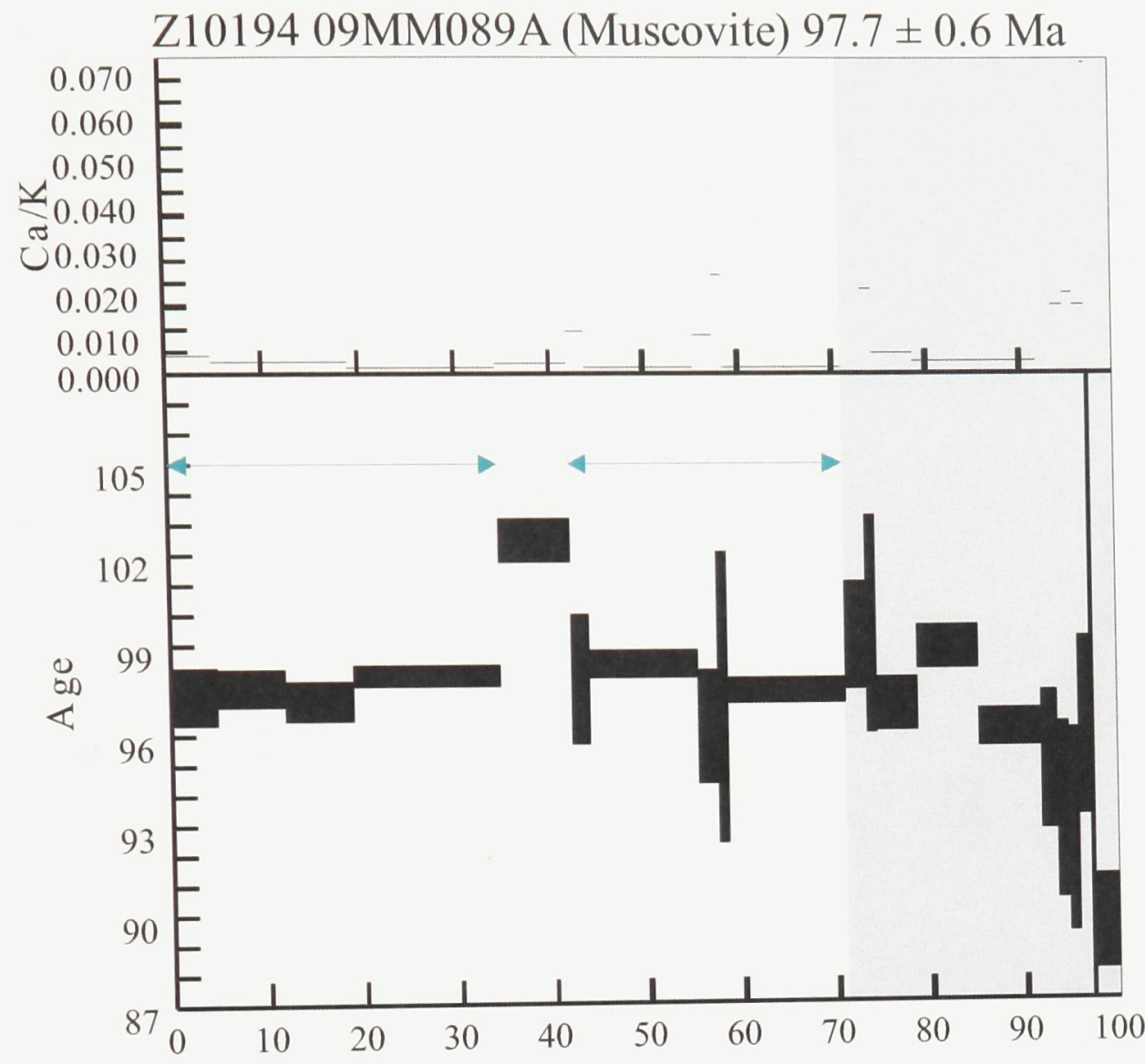

A)

$$
\% \text { 39Ar }
$$

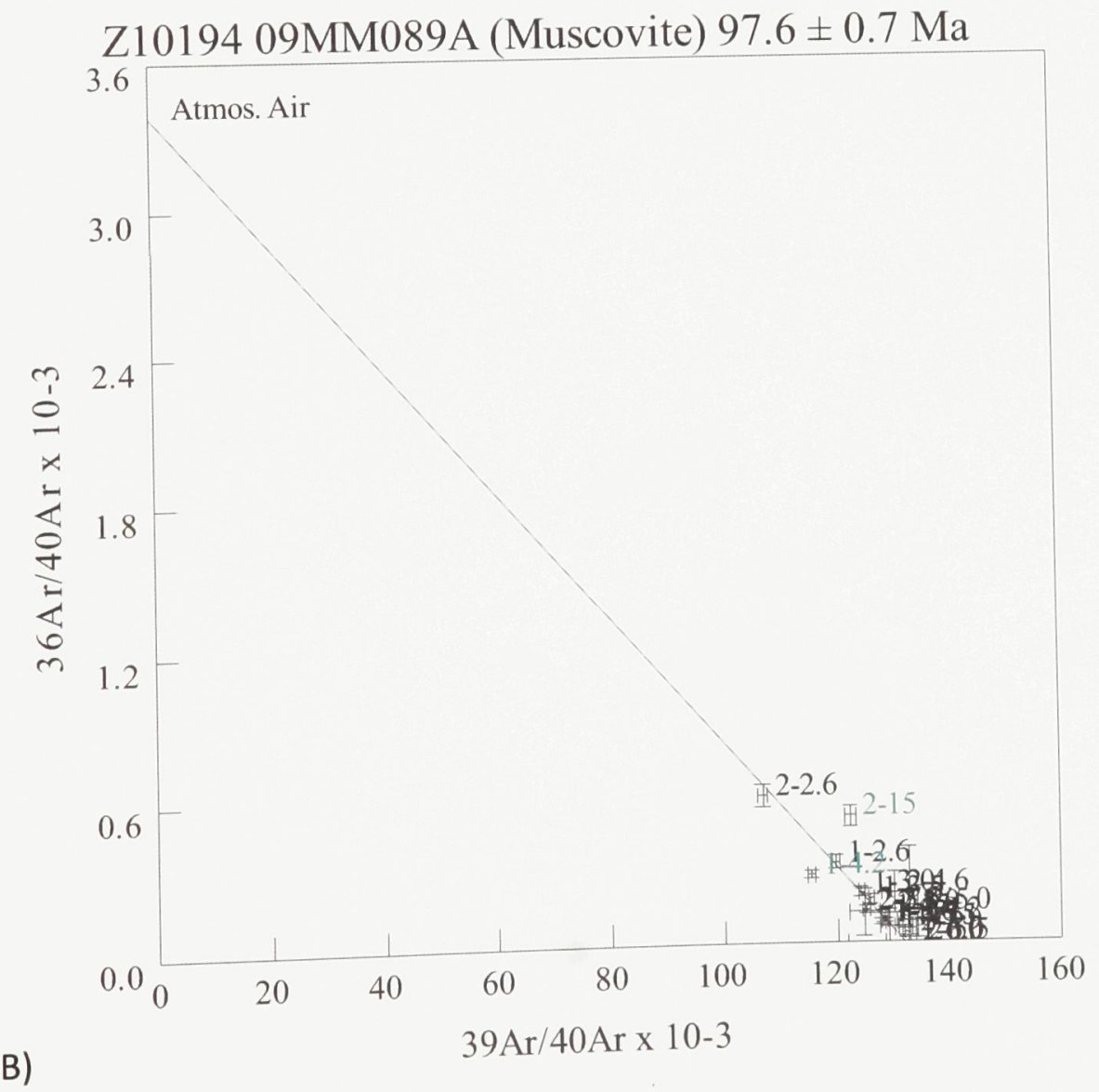




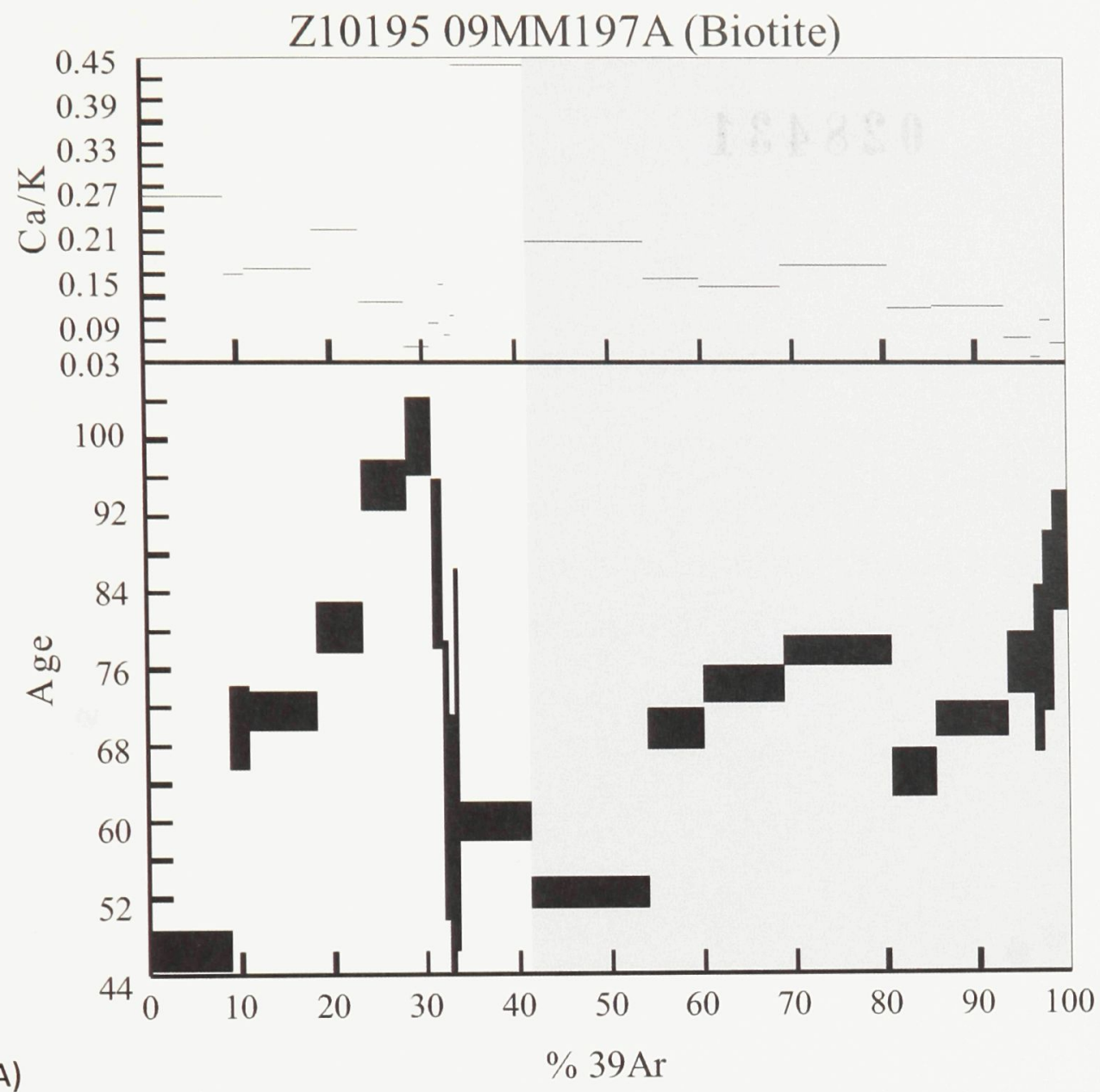

A)

\section{Z10195 09MM197A (Biotite)}

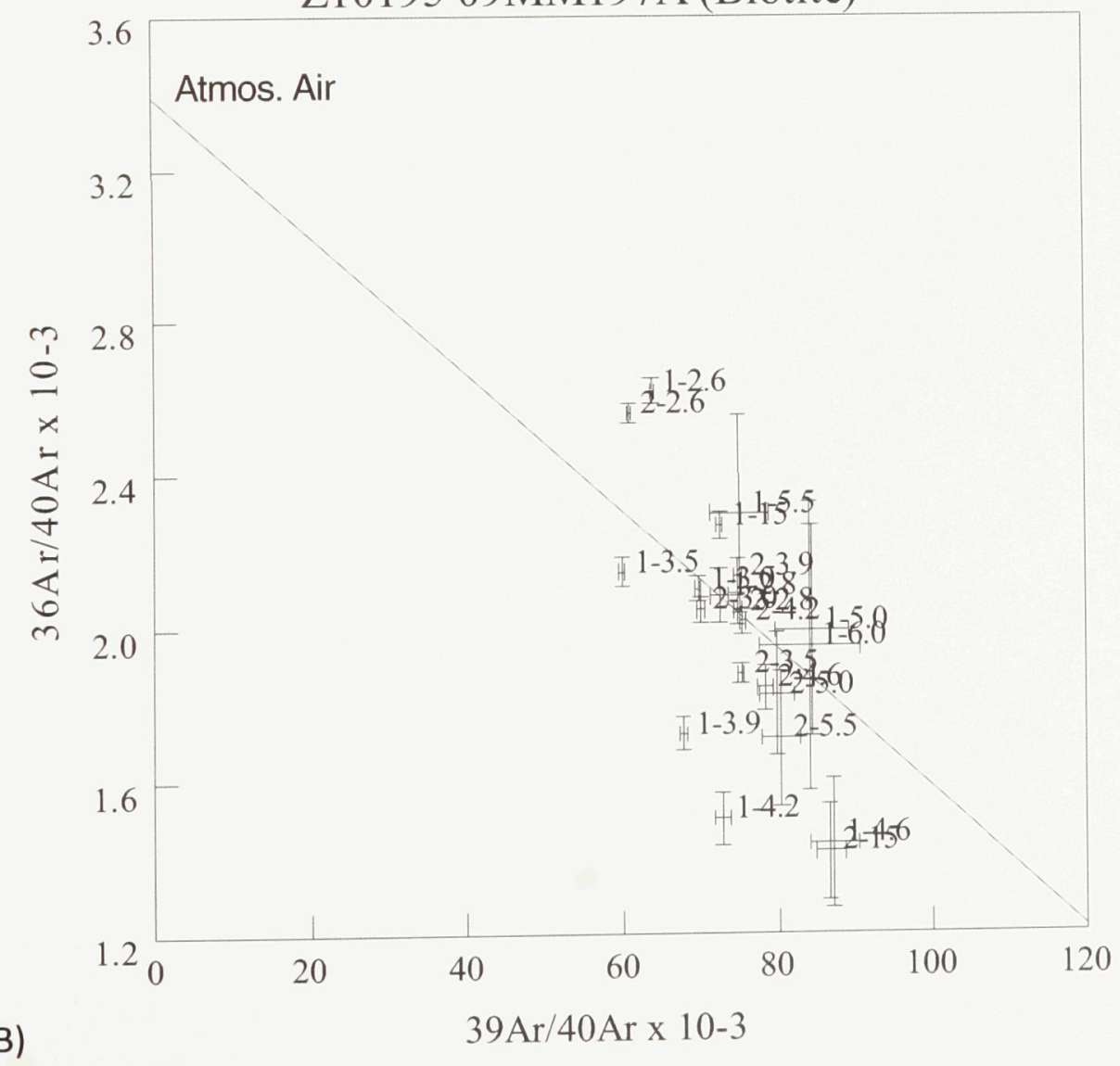

